\title{
Life at the continental-marine interface: palaeoenvironments and biota of the Alcobaça Formation (Late Jurassic, Central Portugal), with a formal definition of the unit appended
}

\author{
Franz T. Fürsich ${ }^{1} \cdot$ Simon Schneider ${ }^{2}$ (1) Winfried Werner $^{3,4} \cdot$ Berta Lopez-Mir $^{2,5} \cdot$ Colm S. Pierce $^{2}$
}

Received: 20 October 2020 / Revised: 10 February 2021 / Accepted: 25 March 2021 / Published online: 13 September 2021

(C) The Author(s) 2021

\begin{abstract}
The Kimmeridgian Alcobaça Formation of the Lusitanian Basin forms a mixed carbonate-siliciclastic unit between basinal deposits of the Abadia Formation, and fluvial-terrestrial strata of the Lourinhã Formation. This study presents $>2.5 \mathrm{~km}$ of detailed logs of nine outcrop sections of the Alcobaça Formation in its type region. Eight of these sections encircle the Caldas da Rainha Diapir, which was a prominent, emergent, passive salt diapir during the time of deposition. Palaeoenvironments of the unit form a complex mosaic of low- to high-energy, carbonate- or siliciclastic-dominated shallow shelf settings; coastal embayments and lagoons; and coastal plains with rivers, lakes and playas. In the strata, abundant microfauna is often joined by a rich macrofauna, usually dominated by bivalves. Locally, corals, calcareous sponges or oysters form meadows or patch reefs. These autochthonous to parautochthonous remnants of former communities are assigned to 35 benthic macrofaunal associations. The integration of palaeoecological analysis of these associations with microfaunal and sedimentological data provides constraint on their salinity ranges, which range from slightly hypersaline to freshwater. Frequent temporal and spatial salinity fluctuations are attributed to variations in relative sea-level, salt tectonics or climate. The NNE-trending Caldas da Rainha Diapir induced pronounced facies differentiation. Predominantly, non-marine siliciclastic facies in the northwest and carbonate to siliciclastic, marine to brackish facies in the southwest are contrasted by shallow-marine carbonate facies east of the diapir. Comprehensive exposure and well-preserved fossils make the Alcobaça Formation an excellent showcase to demonstrate how biofacies analysis can help to disentangle the interplay of climate changes, sea-level fluctuations and salt tectonics. Based on the improved characterisation of the unit, the Alcobaça Formation is formally defined, and seven members are established.
\end{abstract}

Keywords Kimmeridgian $\cdot$ Macrofaunal associations $\cdot$ Biofacies $\cdot$ Salinity $\cdot$ Diapirism

Franz T. Fürsich

franz.fuersich@fau.de

Simon Schneider

simon.schneider@casp.org.uk

1 GeoZentrum Nordbayern, FG Paläoumwelt, Friedrich-Alexander-Universität Erlangen-Nürnberg, Loewenichstrasse 28, 91054 Erlangen, Germany

2 CASP, West Building, Madingley Rise, Madingley Road, Cambridge CB30UD, UK

3 Bayerische Staatssammlung für Paläontologie und Geologie, Richard-Wagner-Strasse 10, 80333 Munich, Germany

4 GeoBio-Center LMU, Richard-Wagner-Strasse 10, 80333 Munich, Germany

5 Instituto Geológico y Minero de España, Subdelegación de Gobierno, Pza. de España - Torre Norte, 41013 Sevilla, Spain

\section{Introduction}

History of research

The term 'Couches d'Alcobaça' was coined by Choffat (1885: 5,18 ) for a succession of lignites from Fervença near Alcobaça (Fig. 3), including a horizon with brackish-water invertebrate fossils in its upper part. Alternating marine and freshwater deposits occurring at Batalha (Fig. 3) and Ourém (Fig. 1) (the latter containing freshwater molluscs and plant litter) were also assigned to this unit. Choffat (1885) further mentioned abundant trigoniid bivalves from marine intercalations in the lignites of the Couches d'Alcobaça. In the same study, Choffat (1885) introduced the term 'Couches à Lima alternicosta' for deposits in the surroundings of Torres Vedras, Cesareda and Sobral da Lagoa, which he regarded as a potential southern equivalent of the Couches d'Alcobaça. In 


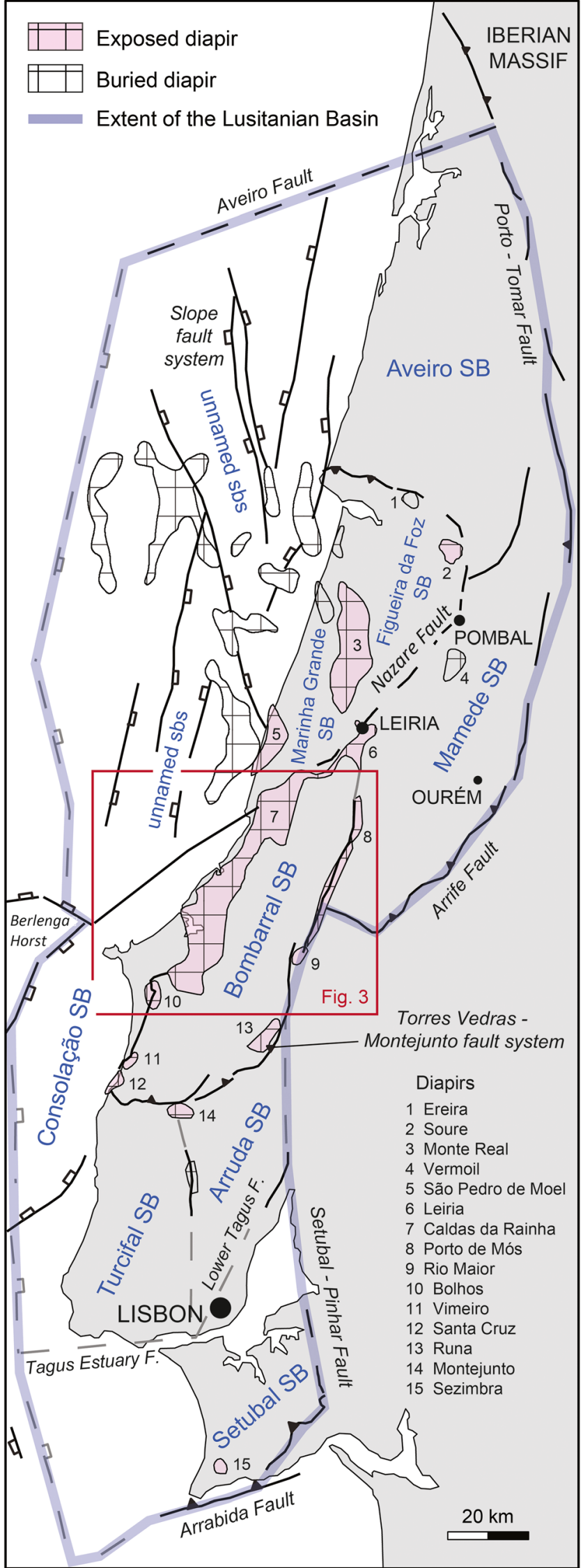

Fig. 1 Main structural elements and sub-basins of the Lusitanian Basin, Portugal. The Aveiro, Figueira da Foz, Marinha Grande, Mamede and Setubal sub-basins are new terms proposed herein. The study region, depicted in Fig. 3, is indicated by a red frame. Modified from Alves et al. (2002)

subsequent papers, Choffat variously included the Couches d'Alcobaça in the 'Marnes d'Abadia' (as a marginal endmember), more generally in the 'Lusitanien' (encompassing all dominantly marine Upper Jurassic rocks), or in the 'Couches à Lima pseudo-alternicosta' (note the name change from above). (The name 'Lima pseudo-alternicosta', attributed to Buvignier by Maync (1959), is an unpublished manuscript name of Choffat and thus not available. The species described by Buvignier is Lima alternicosta, which is a junior subjective synonym of Pseudolimea duplicata (J. de C. Sowerby, 1827); see Fürsich and Werner (1989b).) Finally, in his stratigraphic note in Koby (1904-1905: 159), Choffat regarded the Couches d'Alcobaça as a northern equivalent of the Couches à Lima pseudo-alternicosta. In the Lexique Stratigraphique International, Moitinho de Almeida et al. (1958) listed the Couches d'Alcobaça as part of the Lusitanien.

Zbyszewski and Moitinho de Almeida (1960) and Camarate França and Zbyszewski (1963) issued brief characterisations of the 'Camadas de Alcobaça' and published descriptive logs of representative outcrop sections, which were originally compiled by Choffat; these contain useful information on the thickness, lithology and fossil content of the unit. Ruget-Perrot (1961: 176) summarised the lithology and invertebrate fauna of the Couches d'Alcobaça, also making use of unpublished notes of Choffat. She reported a thickness of 50-200 m for the unit, which she interpreted as the littoral facies of the Marnes d'Abadia (Ruget-Perrot 1961). Witt (1977: 8) introduced the term 'Alcobaça Formation' in an unpublished report of Shell Prospex Portuguesa and provided a concise description of the unit. He characterised the Alcobaça Formation as a shallow-marine to coastal succession of limestones (including oolites, oncolites and coral limestones), marly limestones and marls, with an upward increasing sandstone component. Witt (1977) considered both the contacts to the Montejunto Formation below and to the 'Grés superiores' (= Lourinhã Formation) above as 'possibly unconformable', and reported a total thickness of 300-400 m for the unit. Northward, the Alcobaça Formation grades into the fluvial to continental Lourinhã Formation, and southward into the outer shelf deposits of the Abadia Formation according to Witt (1977). Based on the ammonite-calibrated age of the Abadia Formation, he assumed a Kimmeridgian age for the Alcobaça Formation (Witt 1977). Werner (1986) undertook a detailed analysis of the (bio-)facies of the Alcobaça Formation exposed in the coastal section at Consolação (log reproduced at reduced scale herein), which was assigned to the 'Consolação Member' by Leinfelder (1986). Fatela (1990) 
presented a 75-m log of parts of the Alcobaça Formation exposed at the coast south of Salgado (Fig. 3) and provided basic information on its microfossil content. Bernardes et al. (1991) published a sedimentological analysis of the Jurassic succession between São Martinho do Porto and Nazaré (including the part logged by Fatela 1990). The respective strata, collectively assigned to the Alcobaça Formation herein (see "Geological overview"), were variously attributed to the Camadas de Vale Verde, Camadas com Pholadomya protei, Formação Argilosa de S. Martinho do Porto and Camadas de Alcobaça in their study, partly following a concept outlined in an unpublished PhD (Ellwood 1987). Marques et al. (1992) presented logs of a section at Vestiaria and nearby outcrops and proposed an age model for the unit, based on ammonites (discussed in detail below).

In the explanatory notes to sheet 30-A Lourinhã of the Carta geológica de Portugal, 1:50,000, Manuppella et al. (1999) introduced several informal subunits of the Alcobaça Formation for the succession south of the Serra d'El Rei (Fig. 3), some of them also dated by ammonite biostratigraphy. The basal 'Calcários de Moledo', $120-150 \mathrm{~m}$ thick, are overlain by $180 \mathrm{~m}$ of 'Calcários calciclásticos com oóides, margas e grés de Reguengo Pequeno'. The following 9-12 $\mathrm{m}$ of 'Calcários bioclásticos com corais e calcários oolíticos de Feteira' are considered a lateral equivalent of the Amaral Formation. Along the coast, the 'Grés, margas, calcários oolíticos e dolomites da Consolação', overlain by the 'Grés margas e arenitos da Praia da Armoreira-Porto Novo' (considered part of the Lourinhã Formation by Taylor et al. 2014, and herein) were assigned to the Alcobaça Formation.

Finally, Kullberg et al. (2013), in a review of the geology of the Lusitanian Basin, characterised the Alcobaça Formation as an alternation of variably arenaceous marls, detritic limestones and arenites, with subordinate layers of ferruginous oolites, abundant oncolites, oyster reefs, corals and other marine fauna, and plant remains. The total thickness of the unit is given as $150-200 \mathrm{~m}$, and a Kimmeridgian to basal Tithonian age is assigned. The environmental setting is described as a 'shallow marine carbonate platform with frequent discharge of siliciclastic sediments from the surrounding emergent areas' (translated from Kullberg et al. 2013: 240). Kullberg et al. (2013) further considered the Abiul Formation, exposed in a restricted area east of Pombal, as a distinct unit, comprising predominantly bioclastic and ooidal packstones and grainstones, with subordinate marls and oncolites. A shallow-marine to lagoonal depositional setting with open marine influence was inferred.

\section{Biota}

Goldfuss (1837) was probably the first to describe a fossil from the Alcobaça Formation. His figure and description of Lyrodon muricatum Goldfuss, 1837 (= Myophorella muricata) conform to a species so far only found in the
Alcobaça Formation, although the figured specimen was said to come from Torres Vedras, which is significantly south of the extent of the unit. Sharpe (1850) mentioned Perna lanceolata (presumably Isognomon rugosus), Lithodomus praelongus? (= Lithophaga $\mathrm{sp}$.), Trigonia and corals from Aljubarrota ENE of Alcobaça but did not illustrate his finds. In a series of monographs, titled 'Description de la faune jurassique du Portugal', Choffat (1885-1888, 1893, 1947), de Loriol (1890-1891) and Koby (1904-1905) described and figured marine and freshwater bivalves (Pholadomyidae, Unionida, Trigoniida), brachiopods, echinids and corals from Jurassic deposits of the Lusitanian Basin, including those of the Alcobaça Formation. Starting in the 1960s, the coal mine of Guimarota south of Leiria, now assigned to the Alcobaça Formation (Schudack 2000a), became famous for its rich vertebrate fauna, most prominently an abundance and diversity of Jurassic mammals so far unmatched (Kühne 1961; Martin and Krebs 2000; Martin 2001). From the 1980s onward, a number of papers addressed Late Jurassic ichnofossils (Fürsich 1981a; Neto de Carvalho and Baucon 2010; Neto de Carvalho et al. 2010; Neto de Carvalho 2016) and bivalves (Fürsich and Werner 1985, 1988, 1989a, b; Schneider and Werner 2007; Schneider et al. 2010a, b, 2011) from Central Portugal. Furthermore, benthic faunal associations and palaeoenvironments of several Late Jurassic units, including the Alcobaça Formation, were characterised (Fürsich 1981b; Fürsich and Werner 1984, 1986, 1991; Fürsich et al. 2009). Mateus (2006) compared the biota of the Alcobaça and Lourinhã formations with those from the Morrison Formation (USA) and the Tendaguru Beds (Tanzania), aiming to demonstrate environmental similarities explaining the common occurrence of dinosaur fossils. He and Mocho et al. (2017) also provided overviews of the Late Jurassic dinosaur remains collected from the Lusitanian Basin, including those from the Alcobaça Formation.

\section{Geological overview}

\section{The Lusitanian Basin}

The Lusitanian Basin of Central Portugal is an approximately 300-km-long (north-south), up to 180-km-wide Mesozoic salt-floored extensional basin situated at the Atlantic margin of western Iberia and is subdivided into several sub-basins (Fig. 1). The northernmost sub-basin, named the Aveiro Sub-basin herein (Fig. 1), has only remnants of fluvial Upper Jurassic strata preserved (Boa Viagem sandstones; Carta geológica de Portugal, 1:50,000, sheet 19C Figueira da Foz). The area between the Ereira and Soure diapirs and the Nazaré Fault, previously termed the Monte Real Sub-basin, in fact consists of two sub-basins, separated by the Monte Real Diapir; the name Monte Real Sub-basin is thus not 
suitable. The southwestern sub-basin is named the Marinha Grande Sub-basin and the northeastern one the Figueira da Foz Sub-basin herein (Fig. 1). Further to the west, several unnamed sub-basins extend offshore. The area east of the Nazaré Fault and the Rio Maior-Porto de Mós salt wall is named the Mamede Sub-basin herein (Fig. 1). The established Consolação, Bombarral, Turcifal and Arruda sub-basins follow to the south (e.g. Montenat et al. 1988; Taylor et al. 2014; Fig. 1). The area south of the Tagus, previously termed the Southern Lusitanian Basin (see e.g. Schneider et al. 2009), actually is no more than another sub-basin, named the Setubal Sub-basin herein (Fig. 1).

Basement-involved extension in the Lusitanian Basin was initiated in the Middle to Late? Triassic. A second, prolonged rifting episode occurred from the Sinemurian to the Pliensbachian. Finally, rifting climaxed in a third, much shorter but intense pulse in the Oxfordian (e.g. Ravnas et al. 1997; Rasmussen et al. 1998; Carvalho et al. 2005; Kullberg et al. 2013). The basin is filled with up to $5 \mathrm{~km}$ of sedimentary strata. More than $4 \mathrm{~km}$ of these formed during the Mesozoic and are arranged in four unconformity-bound megasequences (Wilson et al. 1989; Pinheiro et al. 1996; Leinfelder and Wilson 1998; Carvalho et al. 2005), the lowermost pair of which are relevant to the present study. The earliest, Triassic to middle Callovian megasequence initiated with the deposition of coarse-grained red bed siliciclastic strata (Silves Group), followed by a Rhaetian to Hettangian basin-widedeveloped succession of evaporites, including significant amounts of salt (Dagorda Formation). From the Sinemurian onward, a carbonate ramp system started to develop, with dominantly carbonate rocks deposited on the western slope of the Iberian Massif, and dominantly marly sediments towards the basin depocentre in the northwest (Duarte et al. 2010, 2012). Simultaneously, salt was mobilised above basement-evolved faults and the development of passive diapirs was initiated (Lopez-Mir et al. 2019, 2020; Davison and Barreto 2020; see discussion below). During the Middle Jurassic, a fully developed carbonate ramp system extended over the entire basin, with various shallow- and deep-water carbonate facies recorded (e.g. Azerêdo et al. 2003; Azerêdo 2007; Martins 2008). The first depositional megasequence terminated with the onset of a late Callovian to early Oxfordian phase of non-deposition and widespread erosion (e.g. Azerêdo et al. 1998, 2002).

The overlying, middle Oxfordian to early Berriasian megasequence followed rift climax in the Oxfordian and accounts for up to $2.7 \mathrm{~km}$ of sediments (Alves et al. 2002). During this phase, diapirism started to modify basin geometry and sedimentation more significantly, and distinct sub-basins developed. Deposition commenced in the middle Oxfordian with organic-rich, brackish-water to marine limestones and subordinate siliciclastic strata of the Cabaços Formation, followed by a succession of relatively pure carbonate strata of the Montejunto Formation (middle to late Oxfordian; Fig. 2). Subsequently, deep-water marls and turbidites of the Abadia Formation (latest Oxfordian? to late Kimmeridgian) were deposited in the southern half of the basin (northern Setubal, Arruda and northern Turcifal sub-basins; Fig. 2). From the north (Aveiro, Figueira da Foz and Marinha Grande sub-basins), the fluvial-deltaic, sandstone-dominated succession of the Lourinhã Formation (Kimmeridgian to early Berriasian) started to prograde into the basin (Fig. 2). In the intervening region, the highly heterogeneous Alcobaça Formation (latest Oxfordian to terminal Kimmeridgian) developed at the interface of the sea and the continent (Consolação, Bombarral and Mamede sub-basins). It formed a major component of the halokinetic sequences deposited along diapir flanks (Lopez-Mir et al. 2019, 2020). Towards the end of the Kimmeridgian, the deeper parts of the basin had filled up, the continental-marine interface migrated southward and the Lourinhã Formation prograded over the Alcobaça Formation (e.g. Witt 1977; Alves et al. 2002, 2003; Kullberg et al. 2013). A near-basin-wide middle Berriasian hiatus marks the end of the second megasequence (e.g. Leinfelder and Wilson 1998).

\section{Distribution of the Alcobaça Formation}

The Alcobaça Formation occurs in the Mamede, Bombarral and Consolação sub-basins (Figs. 1, 2 and 3). The northernmost and easternmost exposures of the unit are in the Mamede Sub-basin. Outcrops at the southern and western flanks of the Serra de Sicó, in the area between Pombal (Fig. 1) and Abiul (Carta geológica de Portugal, 1:50,000, sheet 23A Pombal), have been assigned to the Abiul Formation in the literature (Almeida et al. 1990; Kullberg et al. 2013; Kullberg and Rocha 2014). The 'Guimarota beds' of the now disused coal mine of Guimarota, just south of Leiria (Fig. 1), were referred to the Alcobaça Formation by Schudack (2000a). Further exposures in the Mamede Sub-basin exist between Batalha and Porto de Mós at the western flank of the Serra d'Aire (Fig. 3), in the area around the Vermoil Diapir (Fig. 1; Complexo de Vale de Lagares of Teixeira and Zbyszewski 1968) and in a narrow strip just west of Ourém (Fig. 1; sheets 23C Leiria, 27A Vila Nova de Ourém). Most of these outcrops were visited by the present authors but did not yield contiguous sections of more than a few tens of metres in thickness.

In the central Bombarral Sub-basin, the Alcobaça Formation crops out in a narrow band along the western flanks of the Serra de Porto de Mós and Serra dos Candeeiros, extending from south of Batalha as far south as Rio Maior (Fig. 3; sheets 26B Alcobaça, 26D Caldas da Rainha, 27A Vila Nova de Ourém). Farther to the west, the Alcobaça Formation is exposed in a narrow, discontinuous band along the east side of the Caldas da Rainha Diapir (Fig. 3). From just 

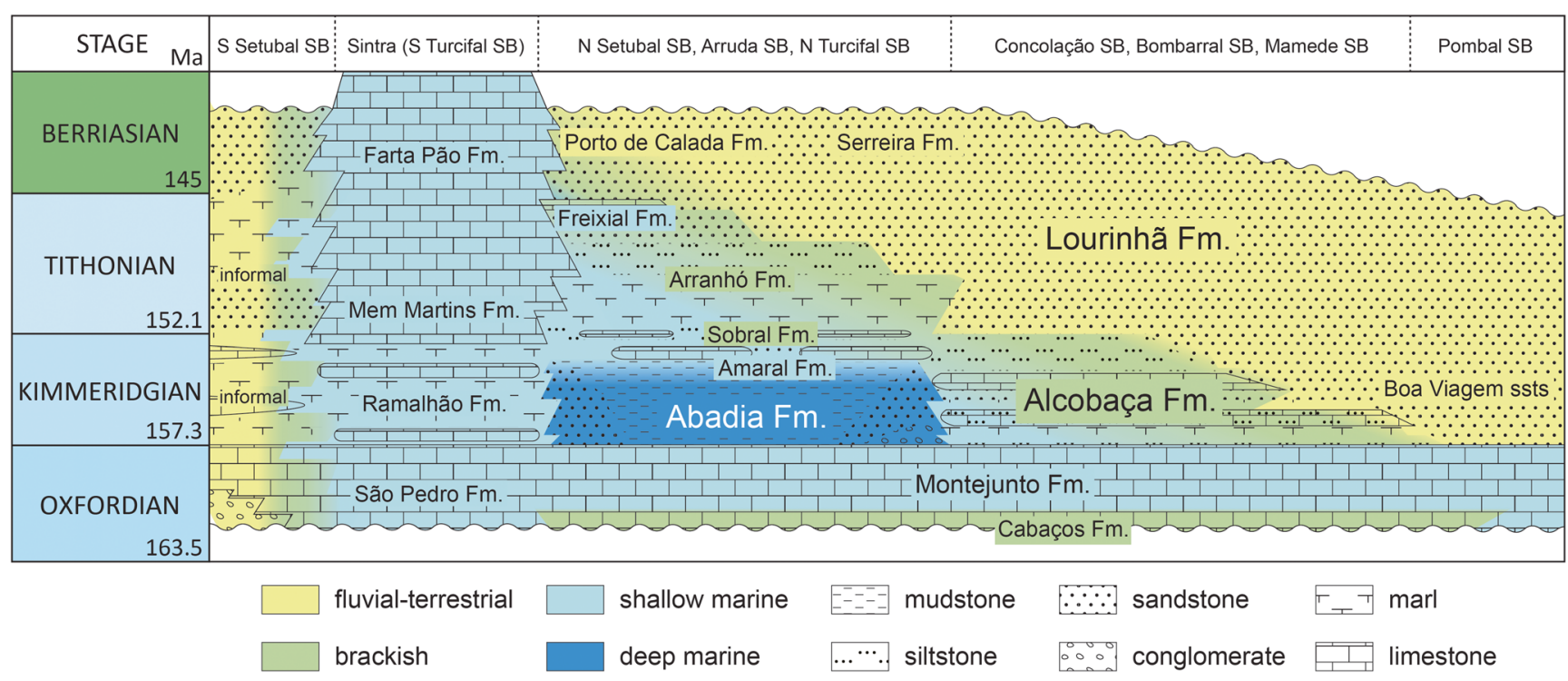

Fig. 2 Lithostratigraphy of the Late Jurassic to Berriasian interval in the Lusitanian Basin

south of the Rio Alcôa, the outcrop follows the diapir flank, turning west in the area of Reguengo Grande, along the southern margin of the Serra d'El Rei, to terminate near Moledo (sheets 26B Alcobaça, 26D Caldas da Rainha, 30A Lourinhã, 30B Bombarral).

West of the Caldas da Rainha Diapir, in the Consolação Sub-basin, the Alcobaça Formation extends from south of Nazaré to the Lagoa de Óbidos (Fig. 3; sheets 26B Alcobaça, 26C Peniche, 26D Caldas da Rainha). The southernmost exposures of the unit are along the coast at Consolação (Fig. 3; sheet 26C Peniche).

\section{Age of the Alcobaça Formation}

Dating the Alcobaça Formation precisely is difficult. Shallow shelf depositional environments within restricted sub-basins result in a dearth of open marine ammonite and dinoflagellate fossils. As a result, useful biostratigraphic markers are rare. Most microfossils are too strongly facies controlled and terrestrial palynomorph taxa too long-ranging to provide precise age control.

Traditionally, the Alcobaça Formation was thought to span large parts, if not all of the Kimmeridgian (e.g. Ruget-Perrot 1961; Witt 1977; Wilson 1979; Fürsich and Werner 1986; Rasmussen et al. 1998; Alves et al. 2002). An alternative stratigraphy was proposed by Pena dos Reis et al. (1996), who divided the Alcobaça Formation into a lower, latest Oxfordian to early late Kimmeridgian portion and an upper, latest Kimmeridgian to Berriasian portion, with the Amaral Formation separating the two parts. No further explanation for this interpretation was provided, and thus it has been largely disregarded.

Several attempts to date the Alcobaça Formation were based on microfauna, macroflora and microflora and palynomorphs. Helmdach (1971a, b, 1974) studied ostracods from the Guimarota coal mine at Leiria and deduced an early Kimmeridgian age for these sediments. Brauckmann (1978) proposed an (early) Oxfordian age for the Guimarota succession, based on the macroflora contained. Likewise, terrestrial palynomorphs and dinoflagellate cysts from the surroundings of Porto de Mós (Mohr and Schmidt 1988) and from Guimarota (Van Erve and Mohr 1988; Mohr 1989) were thought to support (late) Oxfordian ages for part of the succession. Fatela (1990) proposed a late Oxfordian to middle Kimmeridgian age for the coastal section south of Salgado (Fig. 3), based on foraminifera. Schudack (1993, 2000a) concluded a Kimmeridgian age for the Guimarota beds, based on charophytes and ostracods, refuting the earlier stated Oxfordian age.

Three studies refer to ammonites from the Alcobaça Formation. Werner (1986) reported two early Kimmeridgian ammonites, indicative of the Platynota and Hypselocyclum zones, respectively, from Consolação. Marques et al. (1992) proposed an earliest Kimmeridgian (Platynota Zone) to earliest Tithonian (Hybonotum Zone) age for the Alcobaça Formation based on scattered ammonite finds from their Casais (between Vestiaria and Barrio; Fig. 3) and Vestiaria sections (not identical with the section described below). Finally, Manuppella et al. (1999) reported various ammonites from the southern slope of the Serra d'El Rei (Fig. 3), which are indicative of early to late Kimmeridgian ages (Planula/ 


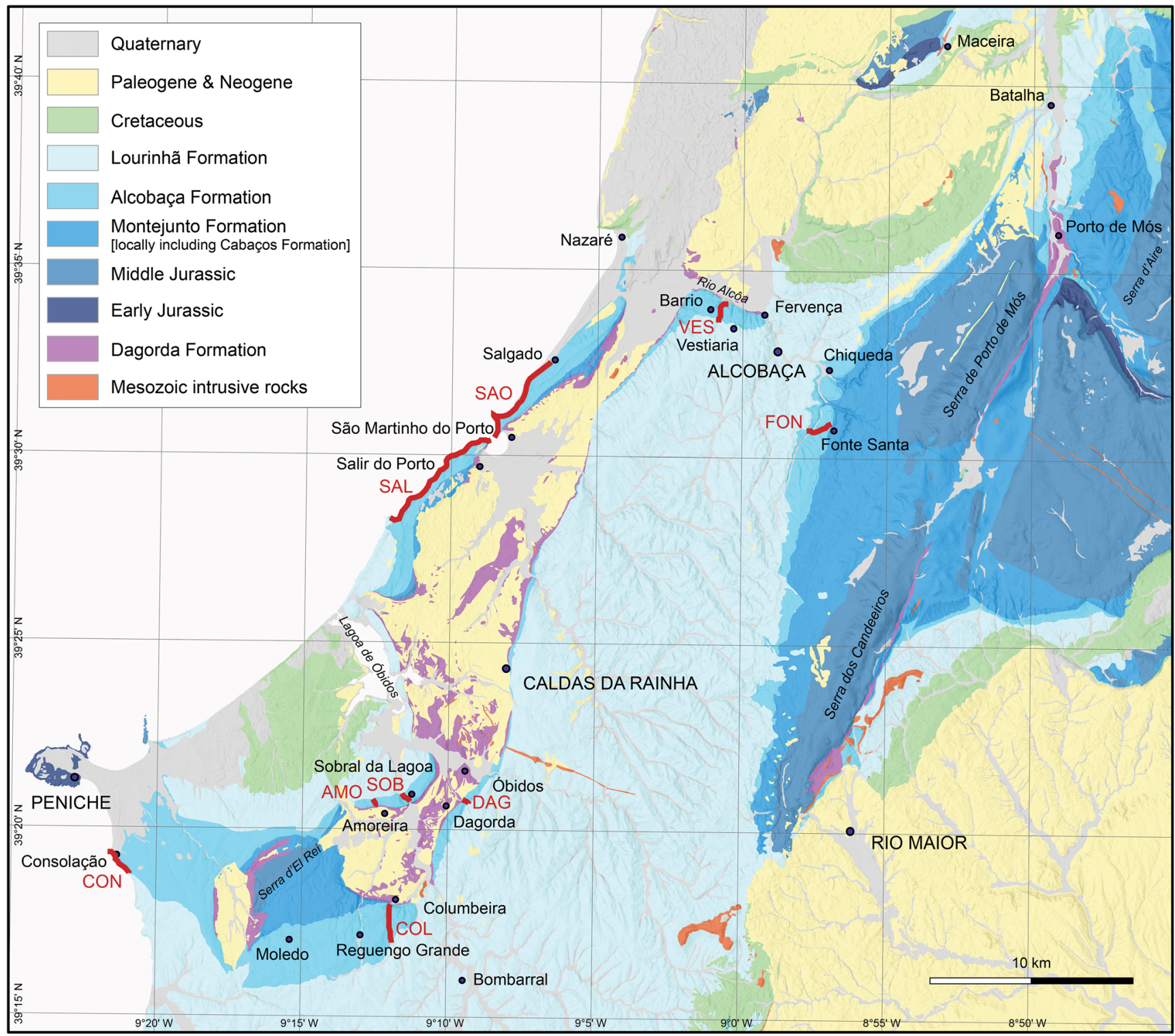

Fig. 3 Geological map of the study region, modified from the 1:50,000 scale map sheets of the 'Carta geológica de Portugal'. Logged sections are indicated by red lines. AMO Amoreira, COL Columbeira, CON Consolação, DAG Dagorda, FON Fonte Santa, SAL Salir do Porto, SAO São Martinho do Porto, $S O B$ Sobral da Lagoa, VES Vestiaria

Platynota to Eudoxus zones). No ammonites were figured, which makes it impossible to verify the taxonomy and resulting age attributions.

Schneider et al. (2009) analysed strontium isotope values of 29 specimens of oysters from the Alcobaça Formation. Ages were calculated using the strontium isotope stratigraphy (SIS) look-up table of Howarth and McArthur (2003) and range from the latest Oxfordian (Planula Zone) to the late Kimmeridgian (lower Beckeri Zone). Recalculating these ages based on the SIS lookup table recently published by Wierzbowski et al. (2017), the range of the Alcobaça Formation has slightly expanded, extending from the basal Kimmeridgian (late
Bimammatum Zone; $156.9 \pm 6 \mathrm{Ma}$ ) to the latest Kimmeridgian (Beckeri Zone; $152.5 \pm 5 \mathrm{Ma}$ ).

\section{Material and methods}

The authors have visited and studied various outcrops of the Alcobaça Formation repeatedly, over a period of nearly four decades. The nine sections described and discussed herein were logged by F.T.F. and W.W. during several field seasons between 1980 and 1987. GPS coordinates of starting points and endpoints of several of the logs were taken in 2016. Outcrop conditions along most of the inland sections, situated along newly 
refurbished roads in the 1980s, have degraded dramatically, while the three coastal sections are still well exposed and accessible.

Sections were measured bed-by-bed. Colour, lithology, grain size, sedimentary structures, diagenetic features, bed contacts, trace fossils, body fossils and taphonomic features such as biofabrics and degree of articulation were systematically recorded. Lithological samples were taken where the lithology could not be determined using a hand lens. Each horizon that yielded a sufficient number of specimens was attributed to a benthic macrofaunal assemblage/association (Fürsich 1981b; Fürsich and Werner 1986). For this purpose, specimens were determined wherever possible at the species level and ranked by relative abundance. The size of samples varied, depending on availability, between 30 and 500 individuals. Apart from identifying specimens in the laboratory, specimens were also counted in the field. Where necessary, bulk sediment samples were taken and then disaggregated and analysed in the laboratory.

Microfossils (e.g. ostracods, foraminifers, charophyte gyrogonites) were obtained from clay and silt samples, disaggregating the rock by immersion in diluted hydrogen peroxide, and subsequent wet sieving to a mesh size of $0.3 \mathrm{~mm}$. Ostracod specimens were picked from dried residues. Selected specimens were sputter coated with gold, and SEM images were taken. Macrofossils were cleaned from adherent sediment using various mechanical preparation techniques. For photographs, most specimens were whitened with ammonium chloride. Several hundreds of thin sections of rock samples, generally $50 \mu \mathrm{m}$ thick, were prepared using standard techniques.

Abbreviations and coordinates of localities (WGS84 datum)

Logged sections of the Alcobaça Formation: $\mathrm{AMO}=$ Amoreira (39.34759, -9.20684 to $39.35373,-9.20177$ ); $\mathrm{COL}=$ Columbeira (road section: $39.2918,-9.19924$ to 39.30171, -9.19932); CON = Consolação (39.32457, -9.36151 to 39.31232, -9.34679); DAG = Dagorda (base of section, former quarry SE Dagorda, near 39.34193, -9.16825); FON = Fonte Santa (road section near 39.52335, -8.95225); SAL = Salir do Porto (39.50858, -9.15239 to 39.47342, -9.20301); SAO = São Martinho do Porto (39.51042, -9.14357 to $39.54367,-9.11401)$; SOB = Sobral da Lagoa (39.34801, -9.18865 to $39.35106,-9.19371)$; VES = Vestiaria (road section: $39.56882,-9.00305$ to 39.56228 , -9.00716 ; NW of village: $39.56485,-9.0094$; NE of village: 39.56599, -9.00505).

Members of the Alcobaça Formation: ARR = Arrinhada; COL = Columbeira; $\mathrm{CON}=$ Consolação; GRA = Gralha; SAO = São Martinho; SGD = Salgado; VES = Vestiaria.

Additional localities of the Alcobaça Formation studied: BAR = Barrio (39.56825, -9.02117); CAR = Carrascal (approximately 39.5315, -8.94559 ); $\mathrm{CHI}=$ Chiqueda (between $39.54069,-8.94894$ and $39.54205,-8.94396)$.
Additional localities mentioned, exposing younger lithostratigraphic units: SAR = Serra d'Arrábida; ESP = Cabo Espichel; STC = Santa Cruz.

\section{Repositories}

Most of the materials this study is based on, as well as the detailed documentation of the sections, including field notebooks and original drawings of the logs, are deposited in the Bayerische Staatssammlung für Paläontologie und Geologie, Munich, under the main inventory numbers SNSB-BSPG 1984 XXI, 1984 XXII, 2002 IV and $2005 \mathrm{~V}$. It should be noted that thin sections, microfossil samples and macrofossils are generally indexed to the bed numbers noted in the original logs. Further material, e.g. macrofossils and ichnofossils figured in previous publications or herein, is deposited in the Museu Geológico of Lisbon (acronym GML).

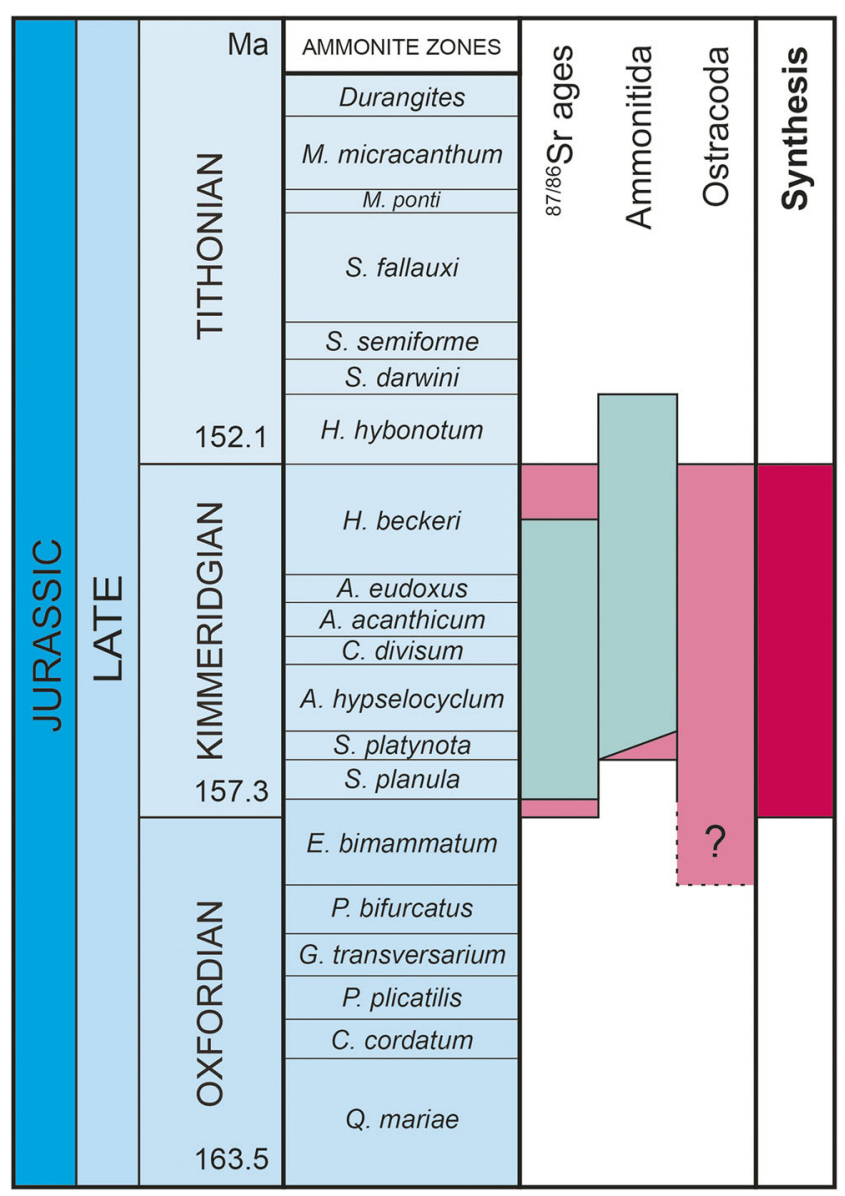

Fig. 4 Age model of the Alcobaça Formation. Turquoise bars indicate ranges taken from the literature. Pink bars indicate ranges adjusted or documented herein 


\section{Revised age model}

\section{Ammonoidea}

Ammonites, if available, are the preferred biostratigraphic tools for dating Upper Jurassic rocks. From the Alcobaça Formation, 15 ammonite taxa are reported in the literature, most probably representing as many specimens. Finds from Consolação were assigned to Mesosimoceras and Ataxioceras, indicating an early Kimmeridgian age (Platynota to Hypselocyclum zones) (Fig. 4), but were neither described nor figured (Werner 1986). From two closely adjacent sections at Vestiaria and Casais, Marques et al. (1992) reported Ataxioceras (Parataxioceras) aff. gr. praehomalinum Atrops, Ataxioceras (Parataxioceras) sp. and Orthosphinctes (Lithacosphinctes) aff. gr. pseudoachilles (Wegele) (all Platynota Zone), Taramelliceras (Taramelliceras) compsum (Oppel) and Glochiceras sp. (Divisum-Acanthicum zones transition) and Hybonoticeras sp. (HybonotumAlbertinum [= Darwini] zones transition) (Fig. 4). No specimen descriptions or figures were provided. Subsequently, Manuppella et al. (1999) reported ammonites from two localities at the southern slope of the Serra d'El Rei: Sowerbyceras sp., Phyllopachyceras sp., Orthosphinctes cf. vandellii (Choffat), Lithacoceras subachilles (Wegele), Ataxioceras discobolum (Fontannes) and A. guentteri (Oppel), all from a single level at Vale Tornada, assigned to the Hypselocyclum to Divisum zones, and Nebrodites cf. heimi (Favre) from Feteira (Eudoxus Zone) (Fig. 4). Again, no descriptions or figures are available.

The Ataxioceras specimen from Consolação (Werner 1986; at $70 \mathrm{~m}$ in the $\log$ ) is reclassified as Parataxioceras cf. oppeli (Geyer) and figured herein (Fig. 5e). Six additional ammonite specimens from the Alcobaça Formation are reported from this study, and five of these are depicted in Fig. 5. Taramelliceras kobyi quenstedti Schairer (Fig. 5a), Subdiscosphinctes sp. (Fig. 5c) and Ataxioceras ('Schneidia') sp. all come from a single outcrop at Barrio. Two specimens of Lithacosphinctes cf. janus (Choffat) were collected in the middle part of the Sobral da Lagoa section (approximately at $90 \mathrm{~m}$ ); one of them is figured (Fig. 5d). Finally, a specimen of Ardescia sp. (Fig. 5b) was collected near Vestiaria, not from the logged road section, but from an outcrop west of the road, corresponding to a height of 350 to $360 \mathrm{~m}$ in the log. All determinations were provided by Günter Schweigert (Stuttgart; pers. comm., 28/08/2020), who interpreted all specimens to indicate an early Kimmeridgian, Platynota Zone age.

\section{Ostracoda}

Due to the absence of ammonites in large parts of the succession, particularly the brackish and freshwater intervals, Ostracoda are considered useful for dating the Alcobaça Formation. The ostracod fauna of the sediments at Guimarota was first studied by Helmdach (1971a, b, 1974) and is now regarded to broadly indicate a Kimmeridgian age (Schudack 2000a, b). A more extensive manuscript, incorporating samples collected by two of the present authors (W.W. and F.T.F.) from several of the outcrops and sections studied herein (CHI, CON, FON, SAL, SAO, VES), was in an advanced stage when Friedrich-Franz Helmdach passed away in 1994 and remained unpublished. Nearly half of the ostracod species recovered were also recorded at Guimarota (see Fig. 6 for a selection). As outlined by Schudack (2000a, b), the distinction of lower, middle and upper Kimmeridgian ostracod assemblages advocated by Helmdach is no longer viable, and a Kimmeridgian age is generally supported by these taxa (Fig. 4). Only for samples from the lower part of the São Martinho do Porto section (Gralha Member; proposed herein), Helmdach had suggested a late Oxfordian age (Fig. 4), based on the presence of a different species of Theriosynoecum (Fig. 6a; T. wyomingense var. pedrogaoense of Helmdach 1974). The ostracod assemblage described by Cabral et al. (2013) from 'the very base of the informal Sobral formation', directly above the 'traditional Alcobaça formation' (i.e. sensu Mannuppella et al. 1999), is considered part of the Lourinhã Formation sensu Taylor et al. (2014) herein. The top of the Consolação Member of the Alcobaça Formation, as proposed below, is situated more than $2 \mathrm{~km}$ further north at the Atlantic coast, probably within the lower São Bernardino Member of Taylor et al. (2014).

\section{Strontium isotopes}

Strontium isotope values extracted from 29 oyster shells from the Alcobaça Formation were published by Schneider et al. (2009). As mentioned above, these values are indicative of basal Kimmeridgian (late Bimammatum Zone; $156.9 \pm$ $6 \mathrm{Ma}$ ) to latest Kimmeridgian (Beckeri Zone; $152.5 \pm 5 \mathrm{Ma}$ ) ages, based on the most recent SIS look-up table of Wierzbowski et al. (2017) (Fig. 4).

\section{Synthesis}

Ammonitida, Ostracoda and strontium isotopes collectively indicate a Kimmeridgian age for the bulk of the Alcobaça Formation. A latest Oxfordian age, suggested for the lower part of the São Martinho do Porto section by Helmdach, based

Fig. 5 Ammonites from the Alcobaça Formation. All specimens assigned to the Platynota Zone (early Kimmeridgian). a Taramelliceras kobyi quenstedti Schairer; Barrio; GML 31980. b Ardescia sp. (macroconch); NW Vestiaria, corresponding to 350-360 $\mathrm{m}$ in the log; GML 31981. c Subdiscosphinctes sp.; Barrio; GML 31982. d Lithacosphinctes cf. janus (Choffat); Sobral da Lagoa section, at $\sim 90 \mathrm{~m}$ in the log; GML 31983. e Parataxioceras cf. oppeli (Geyer); Consolação section, 70 m; C-2-49; plaster cast, SNSB-BSPG 1984 XXI 142. f Ataxioceras ('Schneidia') sp.; Barrio; GML 31984. Scale bars $=10 \mathrm{~mm}$ 


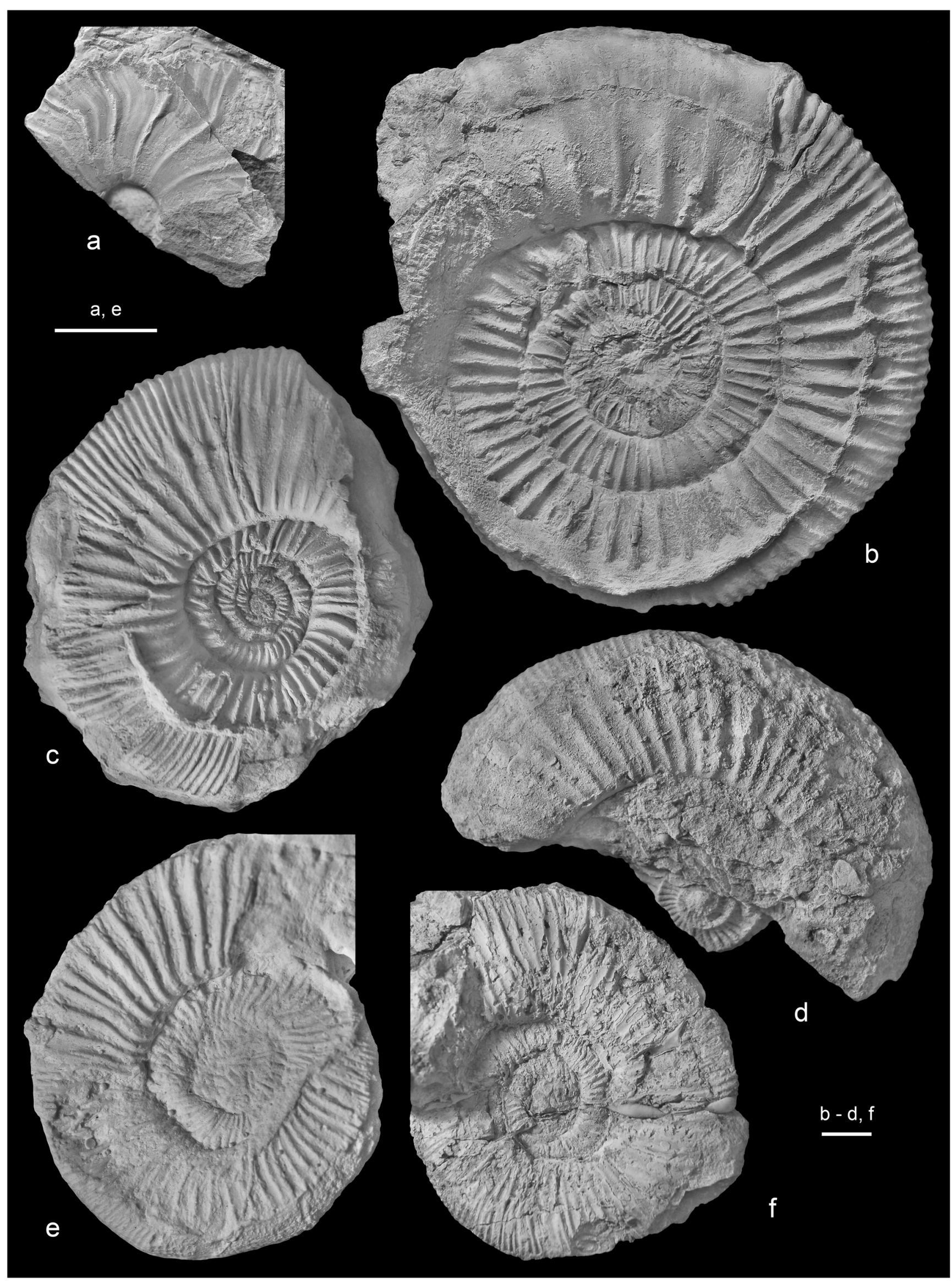


on ostracods (unpublished data) is not supported by strontium isotope values from the same section (Schneider et al. 2009) and is thus considered unlikely. Furthermore, the earliest Tithonian age (Hybonotum Zone) proposed for part of the succession exposed near Vestiaria, based on the presence of Hybonoticeras sp., by Marques et al. (1992), is controversial. The Ardescia sp. illustrated herein (Fig. 5b) was collected from approximately the same level and is supposed to indicate a much older, early Kimmeridgian (Platynota Zone) age. Strontium isotope values of two oysters collected from a distinctive oyster patch reef right below the Hybonoticeras level of Marques et al. (1992) at Vestiaria yield slightly conflicting, early and late Kimmeridgian ages (Hypselocyclum/Divisum and Mutabilis/Eudoxus zones, respectively; $154.6 \pm 6 \mathrm{Ma}$ and $153.9 \pm 5 \mathrm{Ma}$ ), which range in between the ammonite ages. In conclusion, an earliest to latest Kimmeridgian age for the Alcobaça Formation seems well supported (Fig. 4).

\section{Section summaries}

Figure 7 depicts three of the nine outcrop sections logged for this study. In Fig. 8, a key of symbols for the logs presented in Figs. 9, 10, 11, 12, 13, 14, 15, 16 and 17 is provided. Below, the logged successions are briefly characterised, including information on the type and quality of exposure, contacts, assignment to members, lithology, facies and peculiarities, and general interpretation of depositional environments. Two categories of depositional events are marked in the logs, indicating breaks in sedimentation, reversals in trend (transgressive versus regressive) and/or switches from dominantly carbonate to siliciclastic sedimentation or vice versa.

\section{São Martinho do Porto (SAO; Fig. 9)}

Exposure and contacts: This 605-m-thick section is almost continuously exposed (97\% of total thickness) in coastal cliffs north of the bay of São Martinho do Porto (Fig. 7). The contact with the underlying Dagorda Formation is tectonic in nature, and the basal part of the Alcobaça Formation is brecciated. The section is the type locality of the São Martinho, Gralha and Salgado members established herein (see Appendix). The overlying Arrinhada Member is present, but too poorly exposed for logging.

Characteristics: The section starts with $12 \mathrm{~m}$ of beige fine- to medium-grained marine sandstones. These are followed by $60 \mathrm{~m}$ of limestones, some of which contain varying percentages of silt- to sand-sized quartz grains. The limestones are mainly bioclastic wackestones and floatstones with interspersed intraclastic, bioclastic and ooidal grainstones and contain an abundant autochthonous to parautochthonous bivalve fauna dominated by Actinostreon and Isognomon, which form biogenic concentrations. Algal laminites occur near the top of the limestone succession. The carbonate beds are followed by several metres of brackish to marine siliciclastic strata and, subsequently, by a 34-m-thick succession of argillaceous silts and intercalated sandstones (90-124 m; Figs. 7a and 9). A second carbonate intercalation is only $13 \mathrm{~m}$ thick (125$138 \mathrm{~m}$ ) but otherwise resembles the first one in facies and faunal content. The overlying succession starts with a $5-\mathrm{m}$ thick unit of brackish to freshwater lagoonal sediments, which is superseded by an extensive succession (142-559 m) of nonmarine reddish argillaceous to marly silts (Figs. 7a and 9). These commonly contain caliche nodules, some lignite pieces and occasionally the trace fossil Scoyenia. Between these finegrained sediments, fine- to coarse-grained sandstones are intercalated. These exhibit large-scale trough cross-stratification, have an erosional base, fine upwards and change in thickness laterally. They are arranged in several intervals with a broad coarsening-upward trend, topped by medium- to coarse-grained, trough-cross-bedded sandstones. A gradual return to marine conditions is heralded by several brief incursions in the uppermost Gralha Member and becomes evident with the onset of the Salgado Member (559-604 m). From $570 \mathrm{~m}$ onwards, fine-grained sandstones, silt, sandy bioclastic grainstones, bioclastic wackestones and nodular bioclastic marlstone alternate. Oncoidal floatstones to rudstones occur at several levels and are characteristic of the member. A trough cross-bedded sandstone bed at $604 \mathrm{~m}$ at the top of the $\log$ marks the return to dominantly siliciclastic sedimentation.

Fig. 6 Ostracods from the Alcobaça Formation. a Theriosynoecum sp.; São Martinho Mbr; São Martinho do Porto section, 73 m (A 1/20); $L=$ $1.28 \mathrm{~mm}$. b Timiriasevia guimarotensis Schudack; Gralha Mbr; São Martinho do Porto section, $140 \mathrm{~m} \mathrm{(A} \mathrm{1/65);} L=0.46 \mathrm{~mm}$. c Theriosynoecum wyomingense (Branson); Gralha Mbr, São Martinho do Porto section; $140 \mathrm{~m}$ (A 1/65); $L=1.17 \mathrm{~mm}$. d Mantelliana cf. perlata Wienholz; Gralha Mbr; São Martinho do Porto section, 140 m (A 1/65); $L=0.89 \mathrm{~mm}$. e Theriosynoecum wyomingense (Branson); Vestiaria Mbr; Fonte Santa section, $50 \mathrm{~m}(\mathrm{~A} 8 / 1) ; L=0.97 \mathrm{~mm}$. f Cetacella striata (Helmdach); Vestiaria Mbr; Fonte Santa section, 50 m (A 8/1); $L=$ $0.74 \mathrm{~mm}$. g Cytherelloidea aff. weberi Steghaus; Vestiaria Mbr; Vestiaria section, $59 \mathrm{~m}$ (A 15/64); L=0.6 mm. h Poisia bicostata Helmdach; Vestiaria Mbr; Vestiaria section, $69 \mathrm{~m}$ (A 15/78); $L=$ $0.54 \mathrm{~mm}$. i, j Klentnicella rodewaldensis (Klingler); Vestiaria Mbr; Vestiaria section. i $73 \mathrm{~m}$; (A 15/84); $L=0.61 \mathrm{~mm}$. j $73 \mathrm{~m}$; (A 15/84); $L=0.66 \mathrm{~mm}$. k, I Bisulcocypris aff. pahasapensis (Roth); Vestiaria Mbr; Vestiaria section, $393 \mathrm{~m}$ (A 15/168). k $L=1.14 \mathrm{~mm}$. I $L=1.11 \mathrm{~mm}$. m Cetacella inermis Martin; Vestiaria Mbr; Vestiaria section, 393 m (A 15/ 168); $L=0.68$ mm. n Schuleridea cf. minuta Donze; Consolação Mbr; Consolação section, $2 \mathrm{~m}$ (C-1-5); L=0.53 mm. o Cytherella suprajurassica Oertli; Consolação Mbr; Consolação section, $40 \mathrm{~m}$ (C-2-8); L = $0.66 \mathrm{~mm}$. p Paranotocythere sp.; Consolação Mbr; Consolação section, $180 \mathrm{~m}(\mathrm{C}-4-8) ; L=0.4 \mathrm{~mm}$. q Poisia clivosa Helmdach; Consolação Mbr; Consolação section, 180 m (C-4-8); $L=$ $0.5 \mathrm{~mm}$. r Dicrorygma (Orthorygma) aff. reticulata Christensen; Consolação Mbr; Consolação section, $178 \mathrm{~m}$ (C-4-6); $L=0.5 \mathrm{~mm}$ 
Interpretation: Over most of its extent, the São Martinho Member $(0-142 \mathrm{~m})$ records a shallowing-upward succession, initially dominated by shallow-marine sandstones, but switching to a carbonate environment at $19.5 \mathrm{~m}$. The algal laminites in the top part of this interval document intertidal conditions, transitioning into brackish
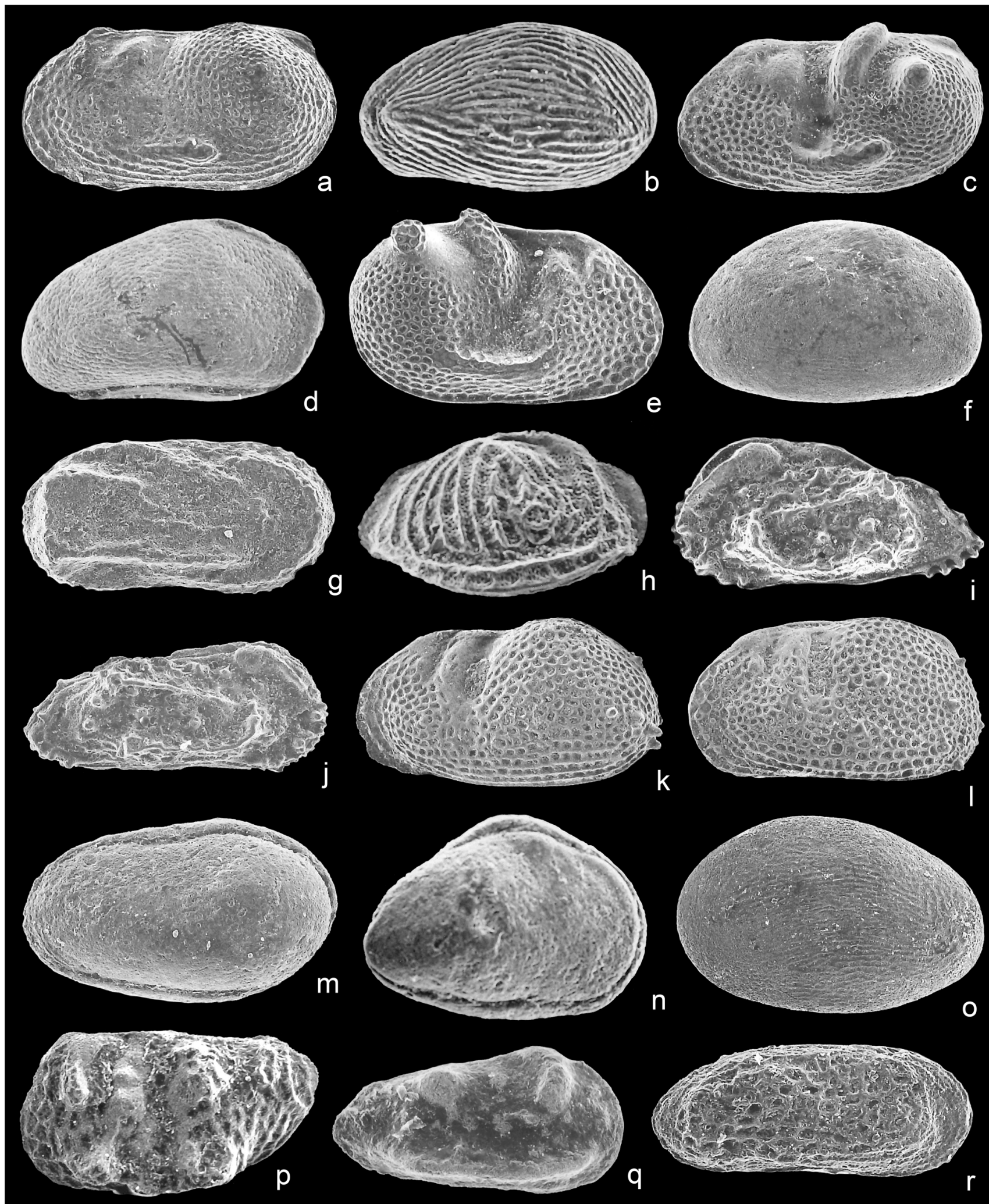
lagoonal $(72-90 \mathrm{~m})$ and floodplain environments $(90-$ $124 \mathrm{~m}$ ) up-section, before briefly switching back to carbonate-dominated, very shallow-marine to brackish conditions (124-142 m). The fine-grained sediments of the overlying Gralha Member $(142-559 \mathrm{~m})$ are typical floodplain deposits, whereas the intercalated sandstones are the fills of fluvial channels. Comparatively thin coarsening-upward units correspond to crevasse splays or indicate phases of increased sediment input, triggered either by pulses of diapirism or climatic fluctuations. Sporadic, metre-thick grey argillaceous silt intercalations with freshwater gastropods are interpreted as deposits of freshwater lakes or lagoons. Equally thin intercalations containing brackish-water gastropods support the general setting of the succession as an extensive coastal plain. This assumption is also corroborated by $1-2-\mathrm{m}$-thick beds with marine bivalves and gastropods, as well as trace fossils such as Psilonichnus, Thalassinoides and Rhizocorallium (particularly in the intervals $418-453 \mathrm{~m}$ and $412-570 \mathrm{~m}$ ). The frequent change between non-marine, brackish and fully marine conditions points to environments at the interface between land and sea. From 457 to $526 \mathrm{~m}$, a thick succession of grey finesandy marly silt with rare freshwater bivalves, lignite pieces and wood fragments is interpreted as representing a shallow coastal lake. Two intercalated siltstone-sandstone packages most likely correspond to lake shore environments. At $565 \mathrm{~m}$, dinosaur tracks (Megalosauripus and Brontopus; Neto de Carvalho 2016) are seen on the tops of two successive clearly marine sandy limestone layers, an obvious evidence of very shallow conditions. The trace fossils Thalassinoides, Teichichnus and Rhizocorallium, and stenohaline bivalves, echinoids, corals and gastropods in the overlying mixed carbonate and siliciclastic succession point to fully marine conditions. However, the presence of some brackish bivalves, caliche nodules and a thin intercalation of red beds with Scoyenia demonstrate that the shoreline was never very far.

\section{Salir do Porto (SAL; Fig. 10)}

Exposure and contacts: The approximately 620 -m-thick coastal section of Salir do Porto, extending southward from the bay of São Martinho do Porto, is the thickest exposure of the Alcobaça Formation documented. The basal contact of the Alcobaça Formation with the underlying Dagorda Formation is tectonic. The lowest part of the Alcobaça Formation, including the first carbonate unit of the São Martinho Member, forms a steep sea cliff and was not logged. The following part of the succession is dissected by a number of faults, which made it impossible to log a continuous section. The log is thus composed of two parts, with a 60-90-m-thick faulted interval missing. The logged succession has near-continuous exposure (98\%) and covers the São Martinho, Gralha, Salgado and Arrinhada members. The latter has its type locality in the section (see Appendix). The Arrinhada
Member is overlain by coarse-grained fluvial sandstones of the Lourinhã Formation.

Interpretation: Except for the marine to brackish interval of the upper São Martinho Member near the base, the first $400 \mathrm{~m}$ of the section represent continental environments of the Gralha Member, for the most part floodplains with scattered ephemeral lakes and small fluvial channels. Most likely, they were part of a coastal plain. This is corroborated by thin intercalations of brackish to marine facies upsection, which are interpreted as lagoonal deposits. As at São Martinho, the sediments are arranged partly in finingupward packages, partly coarsening-upward packages, documenting either shifting crevasse splays, recurrent pulses of diapirism or freshwater run-off. Small-scale, high-frequency oscillations between marine shoal, lagoonal and mudflat environments are recorded in the top part of the Gralha Member. Marine influence culminates in a relatively short transgressional interval at 496-532 m (Salgado Member). However, birdseyes, a rootlet horizon and desiccation cracks indicate very shallow to supratidal conditions, and for the most part sheltered conditions such as protected bays. In the uppermost $90 \mathrm{~m}$ of the succession, which represents the type section of the Arrinhada Member, there is a return to predominantly coastal plain environments with brackish lagoons, small lakes, floodplains, tidal flats and fluvial channels.

\section{Consolação (CON; Fig. 11)}

Exposure and contacts: The coastal section at Consolação, close to $200 \mathrm{~m}$ in thickness, is well exposed (100\%) in low sea cliffs (Fig. 7b, c) and is the type locality of the Consolação Member (see Appendix). The base of the Alcobaça Formation is not exposed. At the top of the unit, the contact with the overlying fluvial sandstones of the Lourinhã Formation is conformable.

Characteristics: Almost the entire succession consists of siliciclastic strata, whereby marly siltstones and fine-grained sandstones commonly form metre-scale coarsening-upward cycles (Fig. 11). Medium-grained sandstones, cross-bedded and

Fig. 7 Examples of logged sections of the Alcobaça Formation. a View from south on the lower part of the São Martinho do Porto section, exposing the São Martinho Mbr and the lower part of the Gralha Mbr; member boundary at $137 \mathrm{~m}$, indicated by yellow stippled line. Approximate position of tectonic contact of the Dagorda and Alcobaça formations is indicated by red stippled line. b View from south on the middle and upper parts of the Consolação section; foreground: silty sediments characterised by brackish water faunas; background: Peniche peninsula. $\mathbf{c}$ View from north on the lower part of the Consolação section (ca. 40-70 m). d Quarry face exposing the basal carbonate-dominated part of the Sobral da Lagoa section; note dinosaur tracks on the layer top to the right (yellow arrow) 

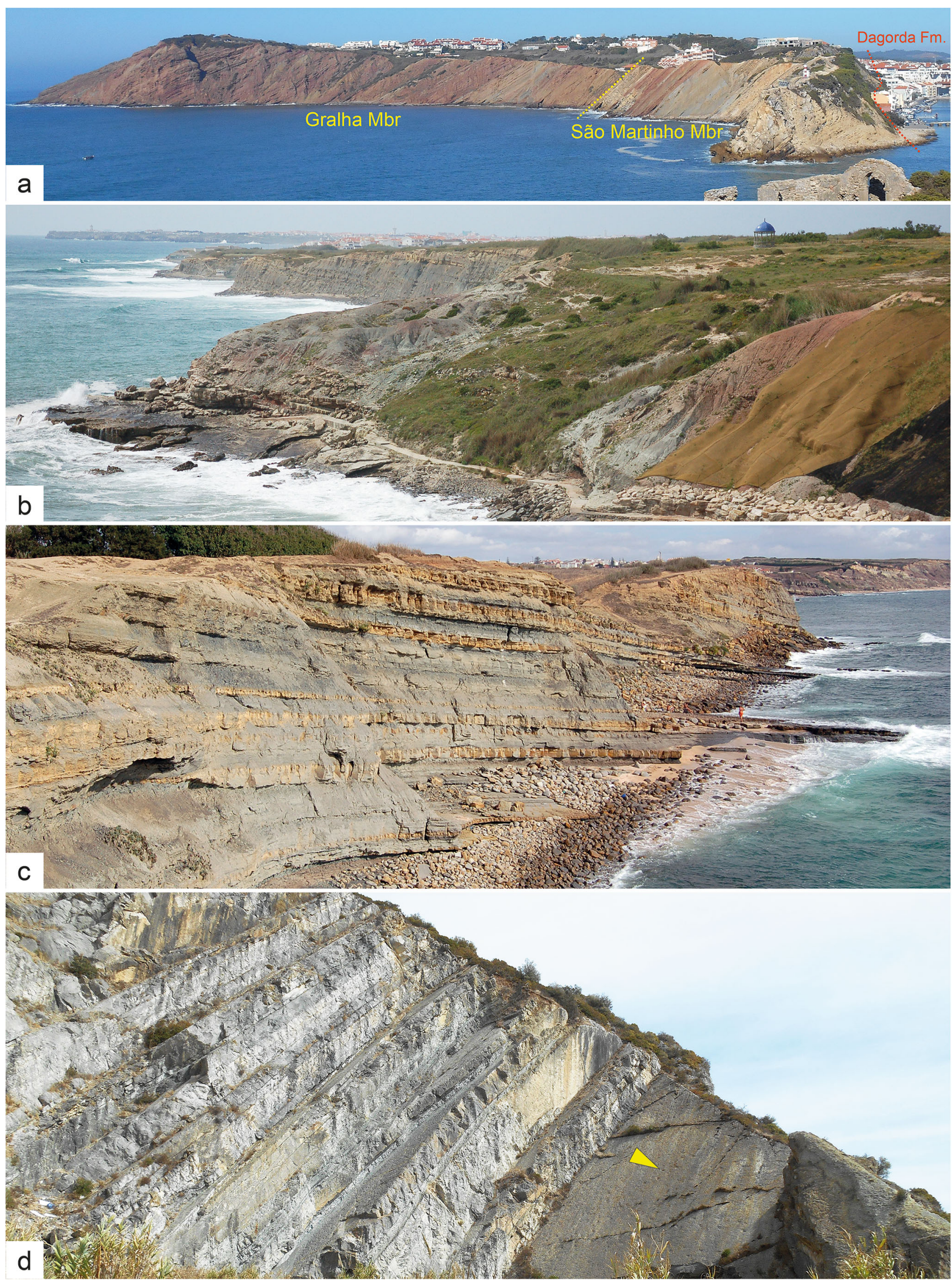


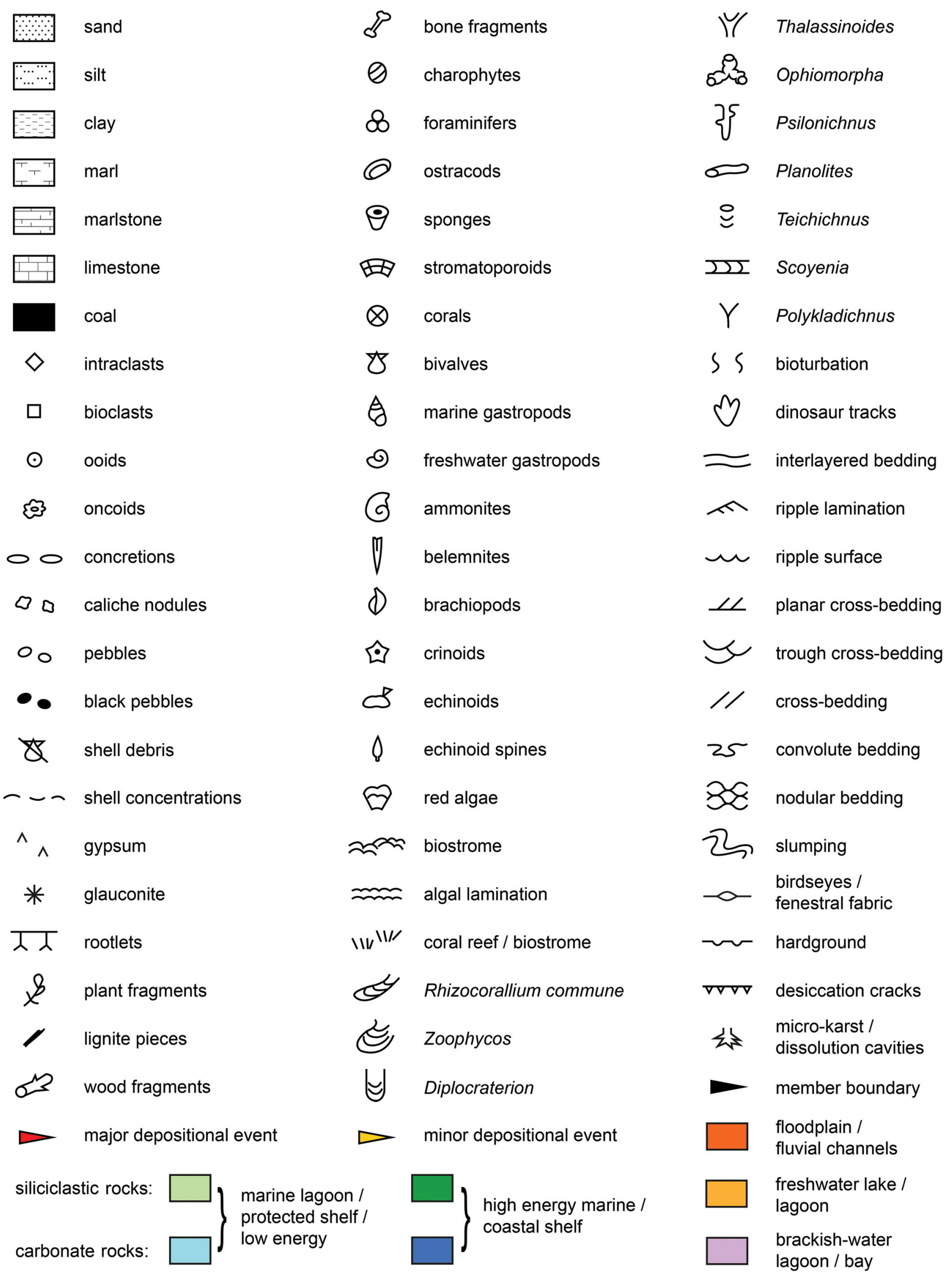

Fig. 8 Key of symbols for logs in Figs. 9, 10, 11, 12, 13, 14, 15, 16 and 17

Springer 

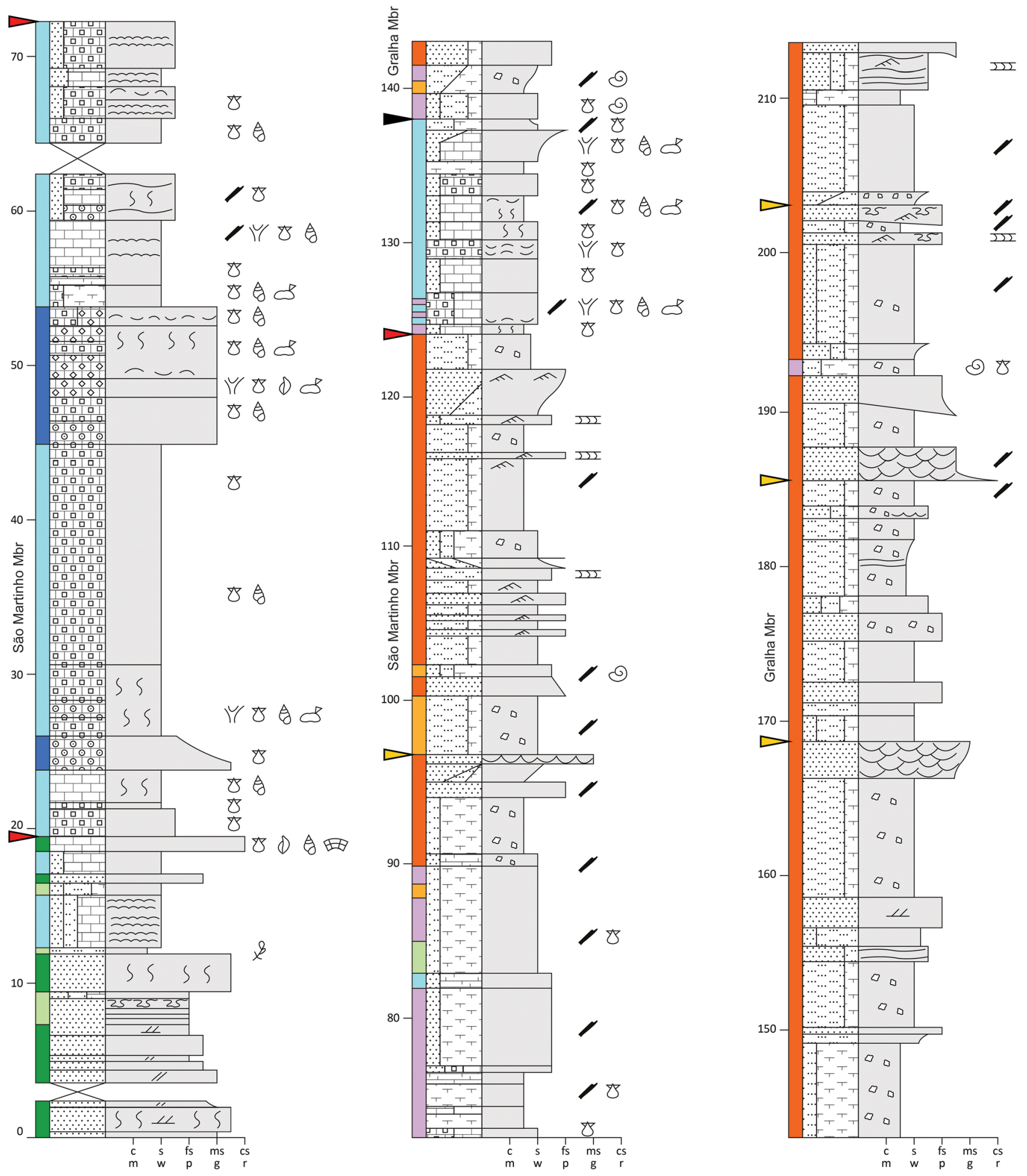

Fig. 9 Schematic log of the São Martinho do Porto section (SAO). See Fig. 8 for the key of symbols 

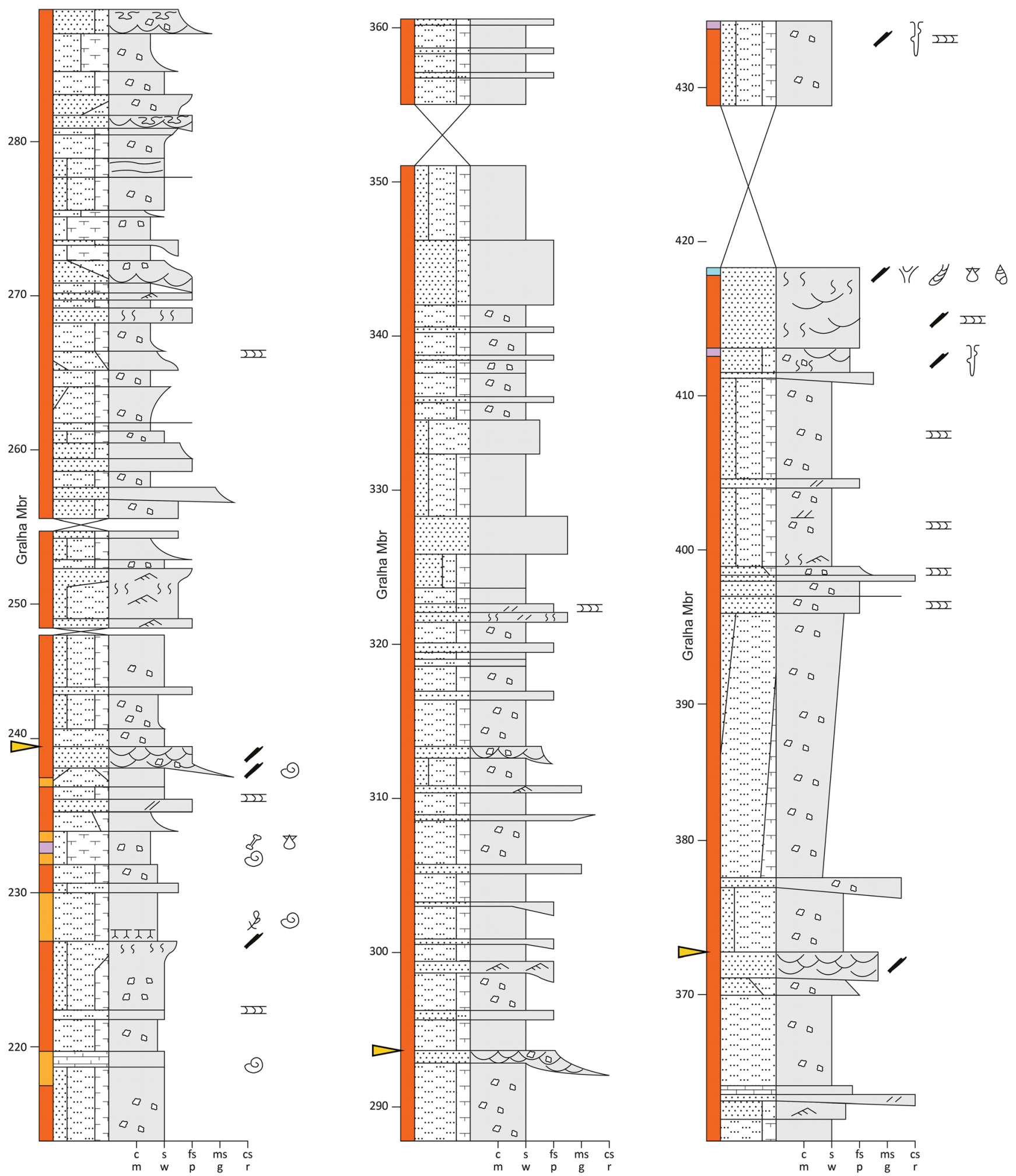

Fig. 9 (continued) 

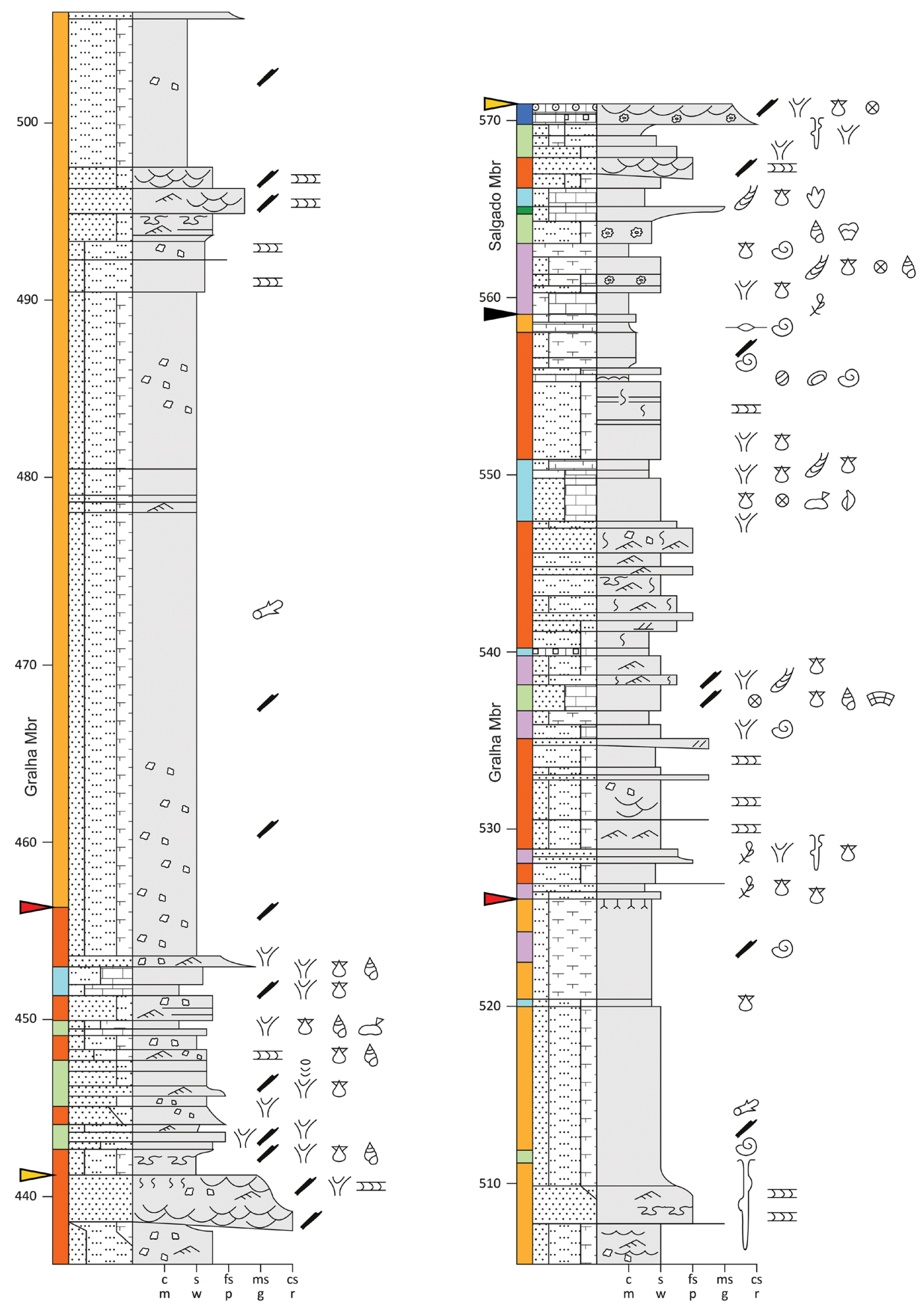

Fig. 9 (continued) 


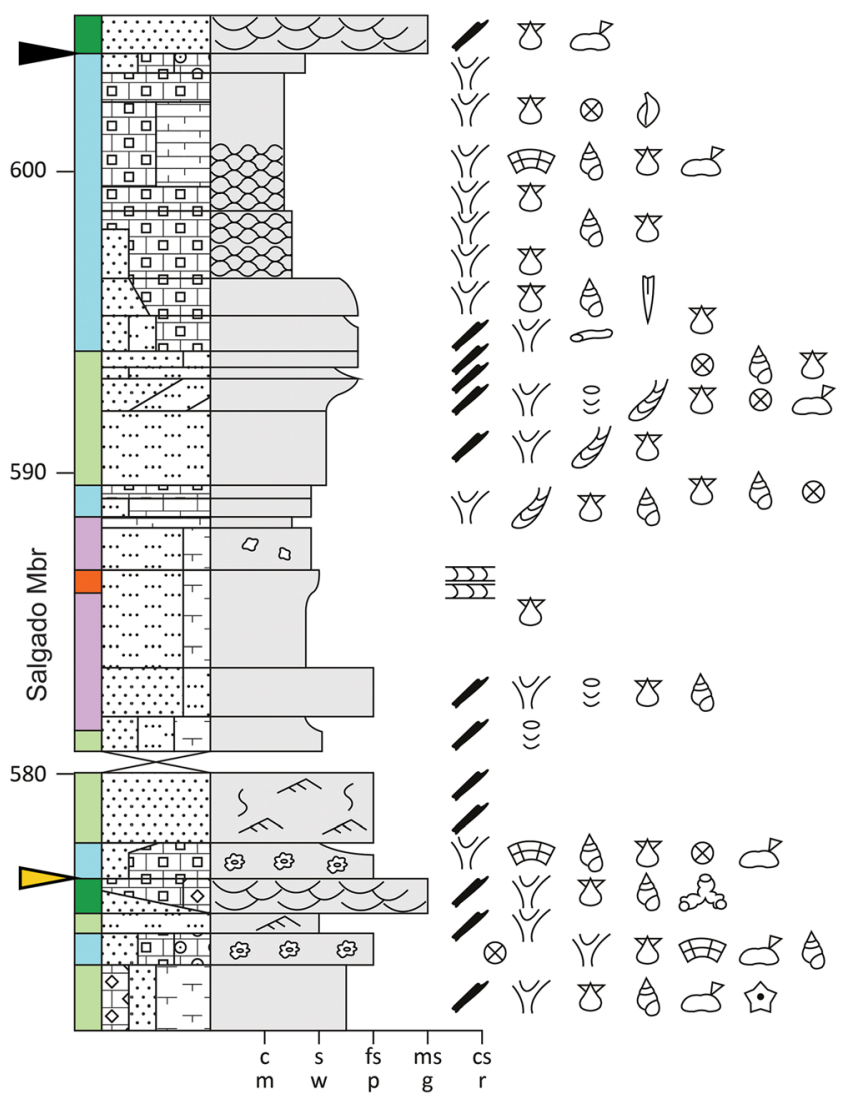

Fig. 9 (continued)

with channelised bases punctuate the section, particularly in the upper part of the succession. The lower $119 \mathrm{~m}$ are strongly bioturbated and contain a diverse, fully marine benthic macrofauna with coral meadows, bivalves, gastropods and rare echinoids. Plant debris and the trace fossils Thalassinoides and Rhizocorallium commune are common. Towards the top of this part of the section, thin packages containing brackish biota become increasingly abundant and dominate from 119 m onwards. Among the benthic macrofauna, gastropods and bivalves prevail, including small patch reefs composed of the oyster Praeexogyra (at $134 \mathrm{~m}$ ). In the marine lower and middle parts of the section, lituolid foraminifera (e.g. Alveosepta jaccardi, Everticyclammina virguliana, Rectocyclammina chouberti, Pseudocyclammina parvula) dominate the microfauna with regard to the number of species and specimens. In the more brackish upper part, assemblages are significantly impoverished in species, often containing only Pseudocyclammina parvula, or foraminifera are absent. Ostracod assemblages exhibit a similar development from generally more fully marine taxa (e.g. Macrodentina tenuistriata, Cytherella suprajurassica, Schuleridea minuta) towards more salinity-tolerant or freshwater species in the uppermost part (e.g. Dicrorygma (Orthorygma) aff. reticulata, Poisia clivosa) (Helmdach and Werner, unpublished data). Trace fossils include Thalassinoides, Diplocraterion and Polycladichnus. Towards the top, the species diversity decreases drastically and caliche nodules occur in some layers, partly scattered (e.g. at 172 $180 \mathrm{~m}$ ), partly concentrated in thin conglomerate layers (e.g. at $150 \mathrm{~m}, 157 \mathrm{~m}$ and $167 \mathrm{~m}$ ).

Interpretation: In general, the Consolação section corresponds to a low- to moderate-energy shallow shelf setting in the lower part (up to $119 \mathrm{~m}$ ), and a protected nearshore environment with increasing freshwater influence in the upper part. Channel sandstones point to deltaic and tidal influence, and a well-sorted low-angle cross-laminated sandstone has been interpreted as a beach deposit (Werner 1986). Numerous small-scale coarsening-upward cycles document minor fluctuations in sea level, probably relating to pulses of diapirism.

Vestiaria (VES; Fig. 12)

Exposure and contacts: The inland road section of Vestiaria is $403 \mathrm{~m}$ thick, but only $47 \%$ of its thickness, particularly in the lower $125 \mathrm{~m}$, was exposed when the section was logged; the upper two-thirds have extensive gaps. Acknowledging that Choffat (1885) established the Alcobaça Beds for outcrops in close vicinity, the Vestiaria section is designated as the stratotype of the Alcobaça Formation and of the Vestiaria Member herein (see Appendix). The basal contact of the unit with the underlying Dagorda Formation is tectonic. The contact with the overlying fluvial sandstones of the Lourinhã Formation is conformable.

Characteristics: A 30-m-thick carbonate unit, composed of bioclastic and ooidal wackestones, packstones, and grainstones, containing an abundant marine fauna of corals, sponges, stromatoporoids, echinoids, brachiopods, bivalves and gastropods, occurs at the base of the section. It is followed by several metres of a transitional, but still fully marine facies (fine-sandy marl), which then turns into red non-marine fluvial channel sandstones. From 52 to $70 \mathrm{~m}$, fine-sandy silty marl and marly fine-grained sandstones partly contain freshwater gastropods or brackish-water bivalves. Up-section finegrained marine siliciclastic sediments with a rich benthic macrofauna including corals, stromatoporoids and echinoids dominate. The benthic microfauna is mainly represented by lituolid foraminifera. Coral meadows occur at two levels (75-79 $\mathrm{m}$ and $95 \mathrm{~m}$ ), as do calcareous sponge meadows (103-105 m). From $107 \mathrm{~m}$ onwards, fine-grained greenish siliciclastic rocks, characteristic of brackish environments, prevail. A return to marine carbonate sedimentation is seen from 149 to $154 \mathrm{~m}$. For the remaining succession, outcrops are sporadic (Fig. 12). They show a range of mainly marine siliciclastic and carbonate facies, among them coralline sponge-coral meadows (231-240 m) extending laterally for 

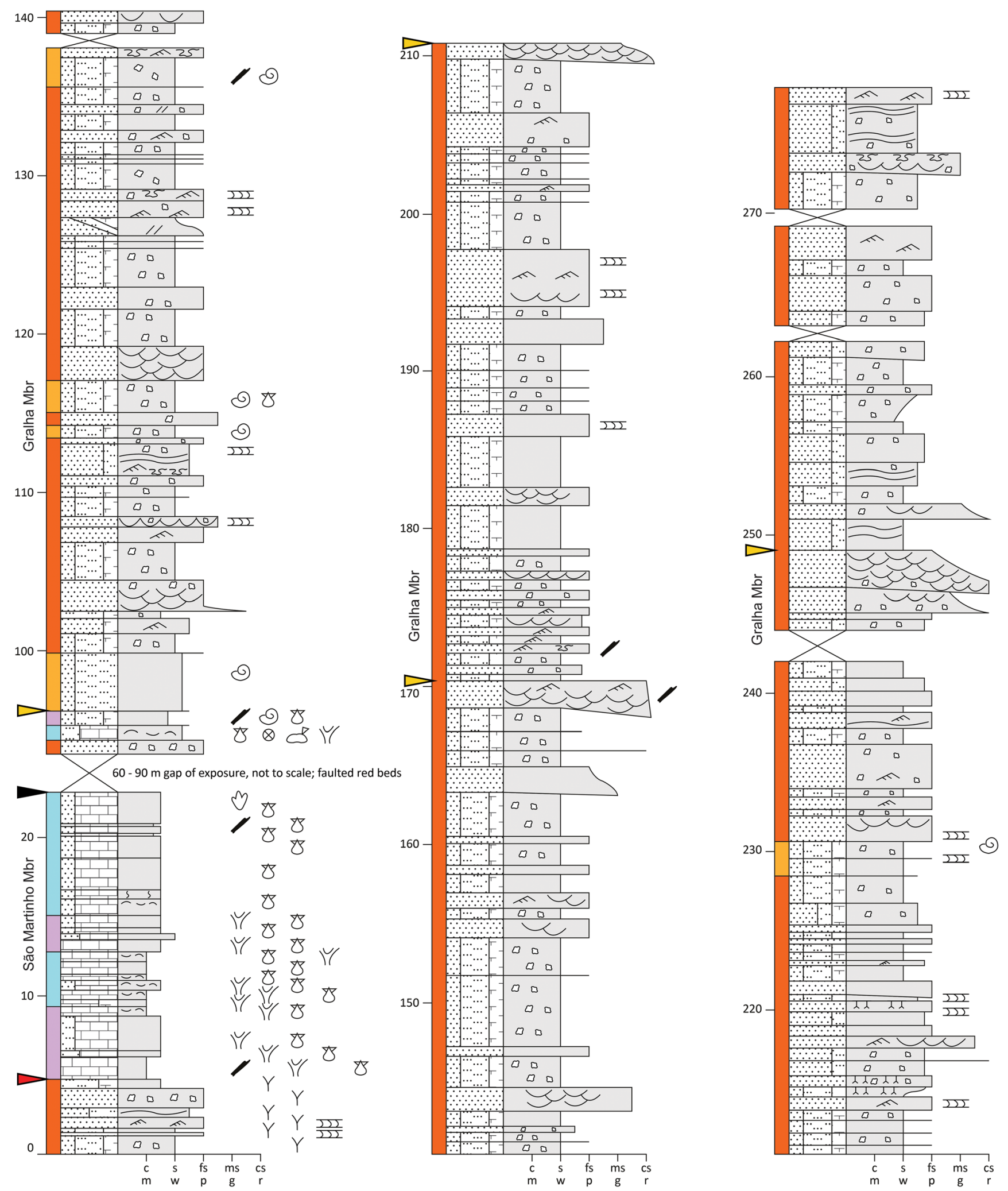

Fig. 10 Schematic log of the Salir do Porto section (SAL). See Fig. 8 for the key of symbols 

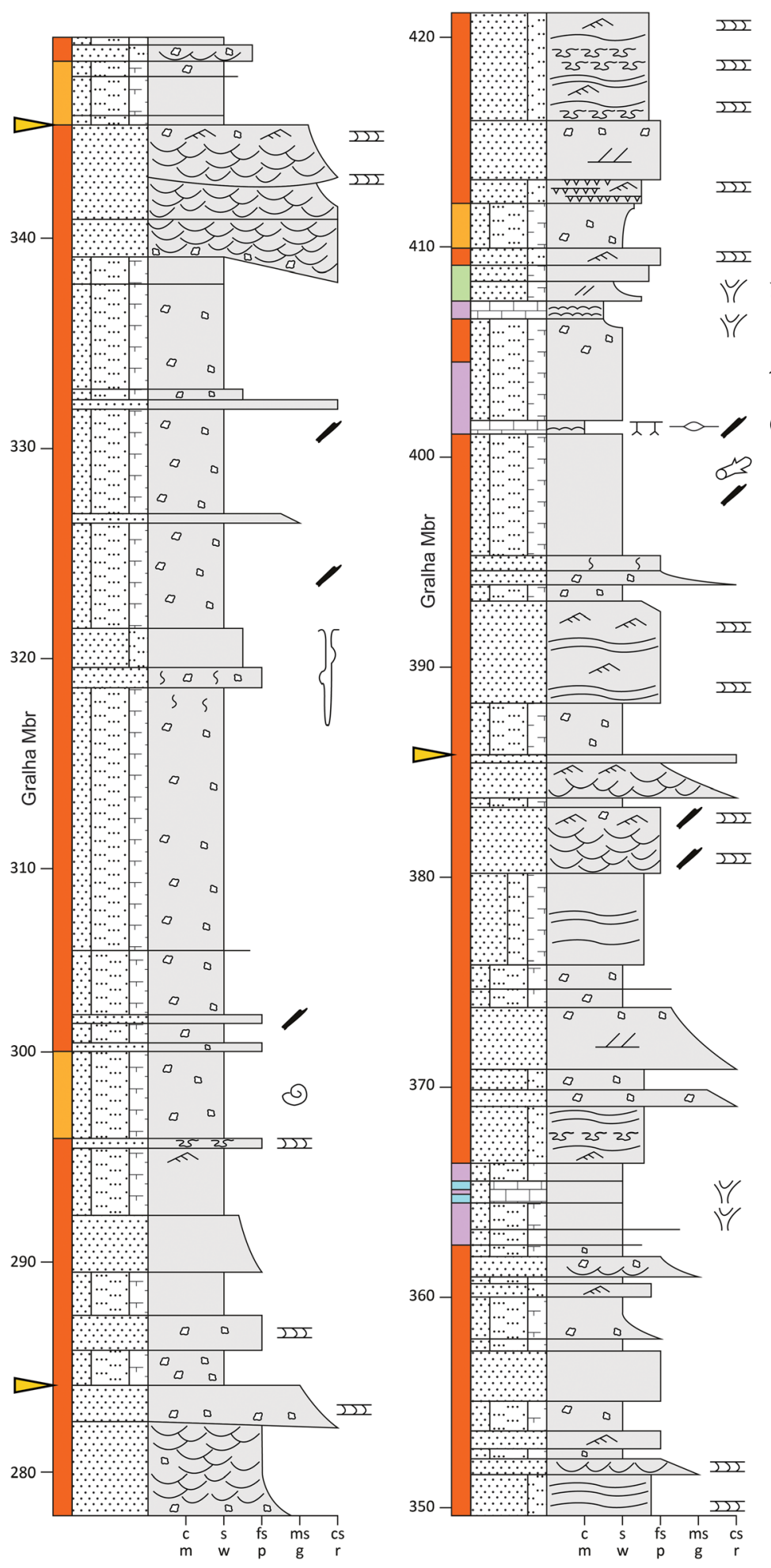

$\because \because \because \cdots) \curvearrowright$

$\theta_{\theta}^{\theta}$

एक

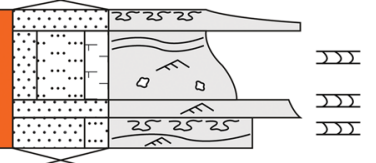

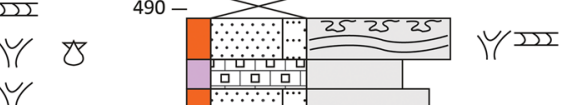

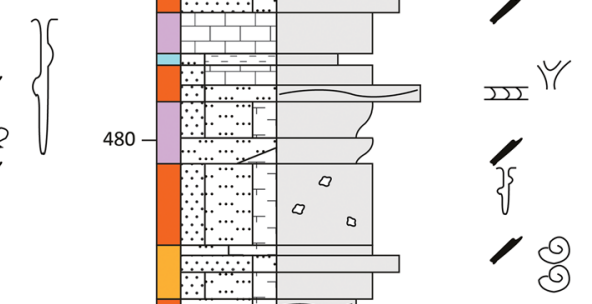
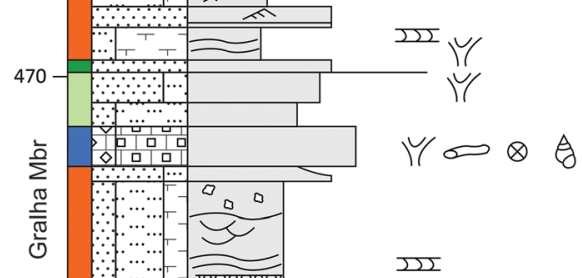

$\sigma \otimes \theta$

西

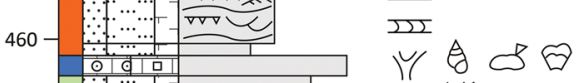

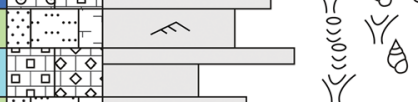

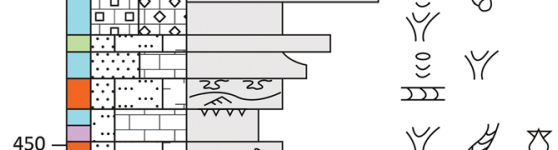

450

Y $\forall \nabla$

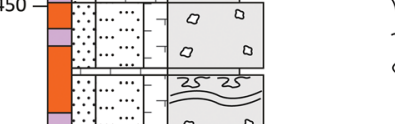

\{\}
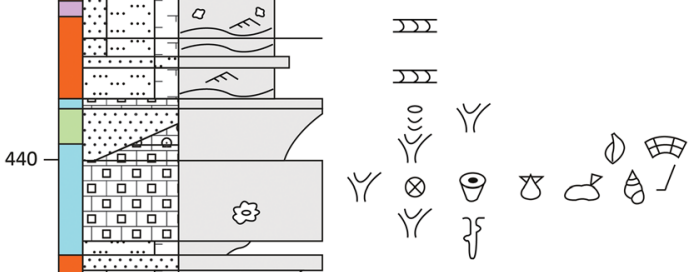

Fig. 10 (continued)

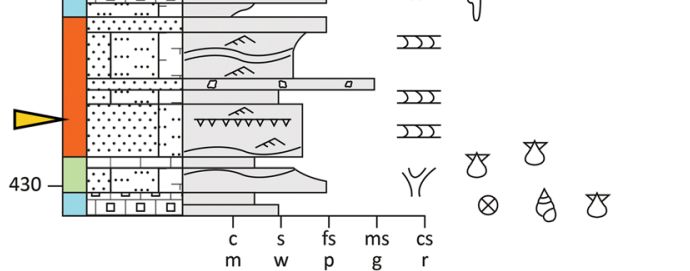



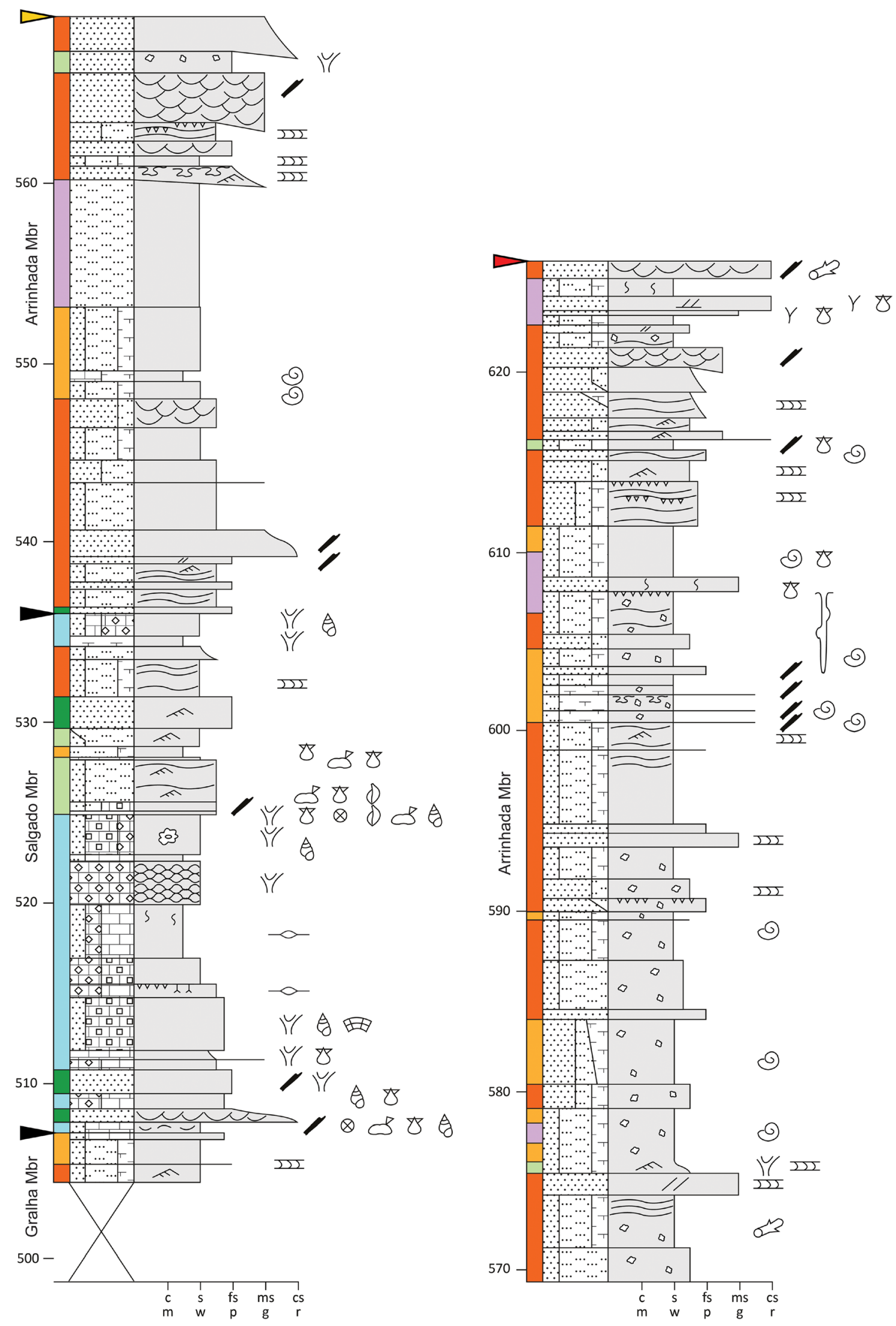

Fig. 10 (continued) 

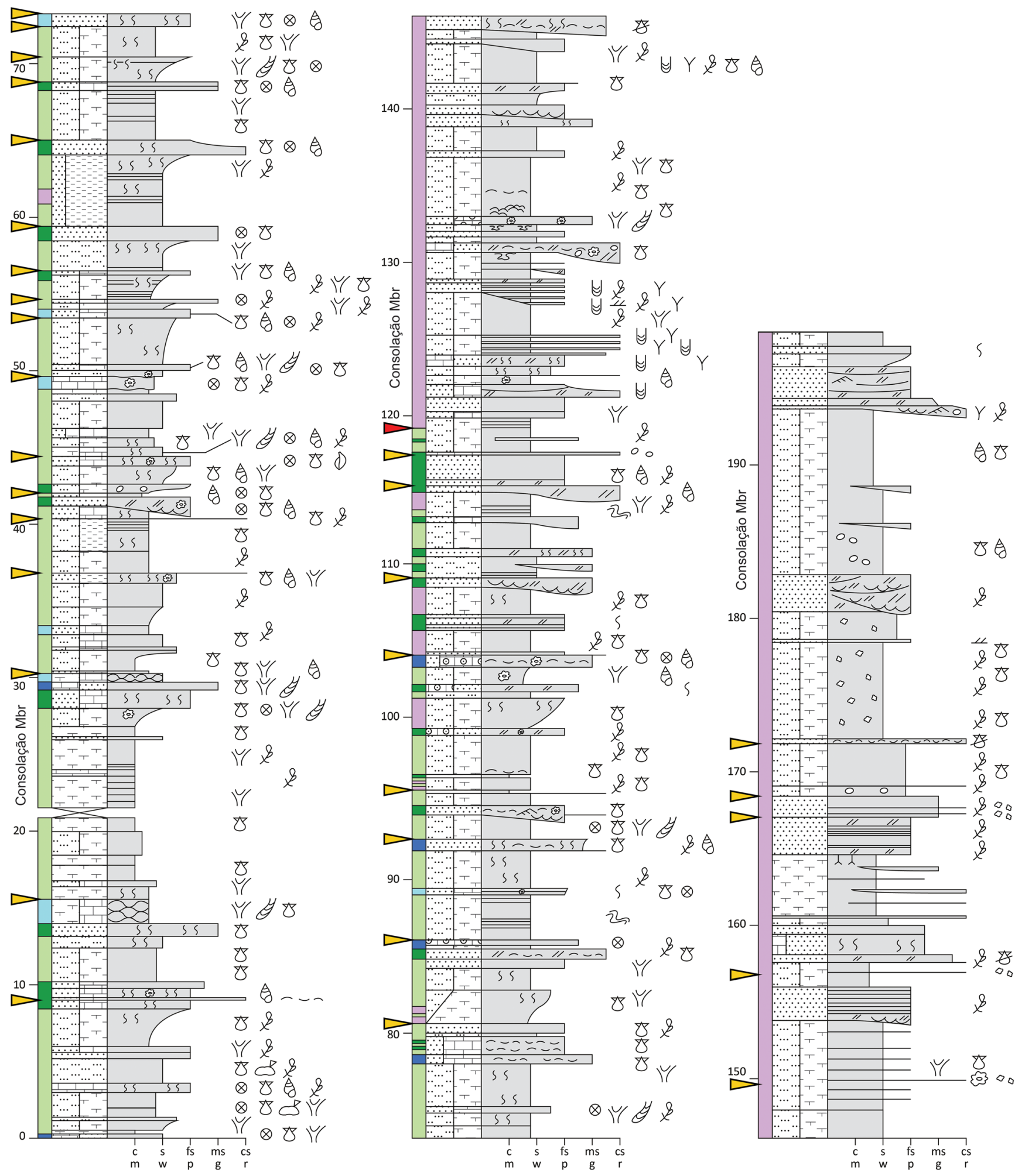

Fig. 11 Schematic log of the Consolação section (CON). See Fig. 8 for the key of symbols

several kilometres (Fürsich and Werner 1991), some brackish silty fine-sandy marl (319-322 m) and a few metres (334$336 \mathrm{~m}$ ) of silty marl containing remains of freshwater organisms (e.g. gastropods [Amplovalvata], ostracods
[Cetacella, Bisulcocypris] and abundant charophyte gyrogonites). The section concludes with marl containing thin layers of coal and a rootlet horizon, followed by a several-metres-thick trough cross-bedded coarse-grained 

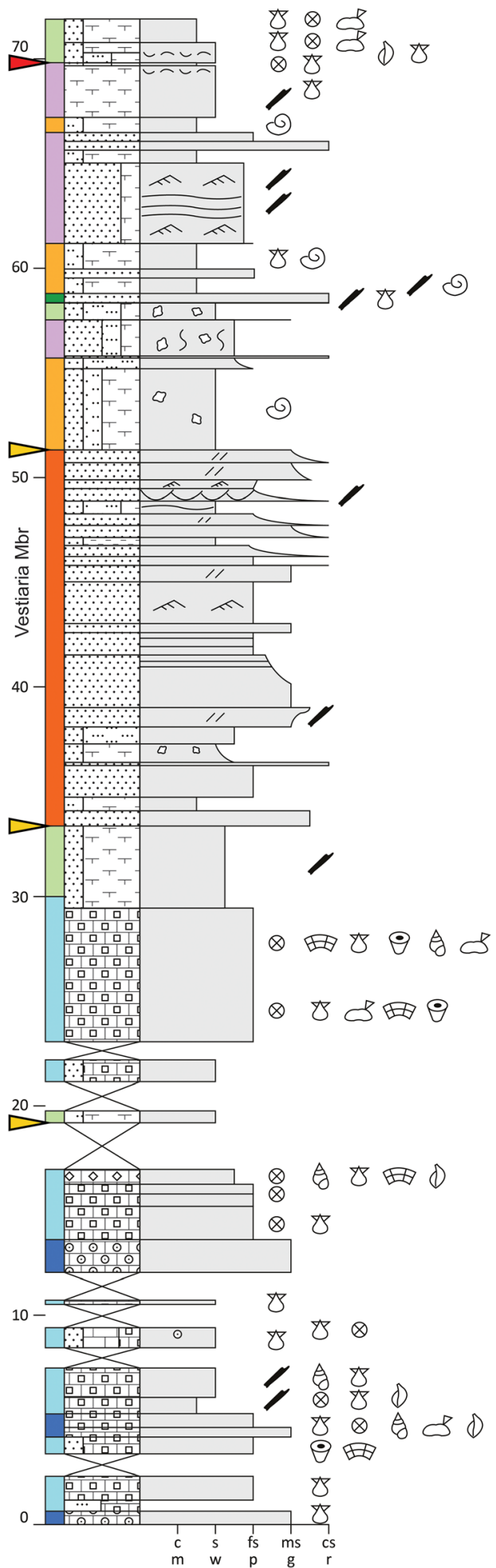

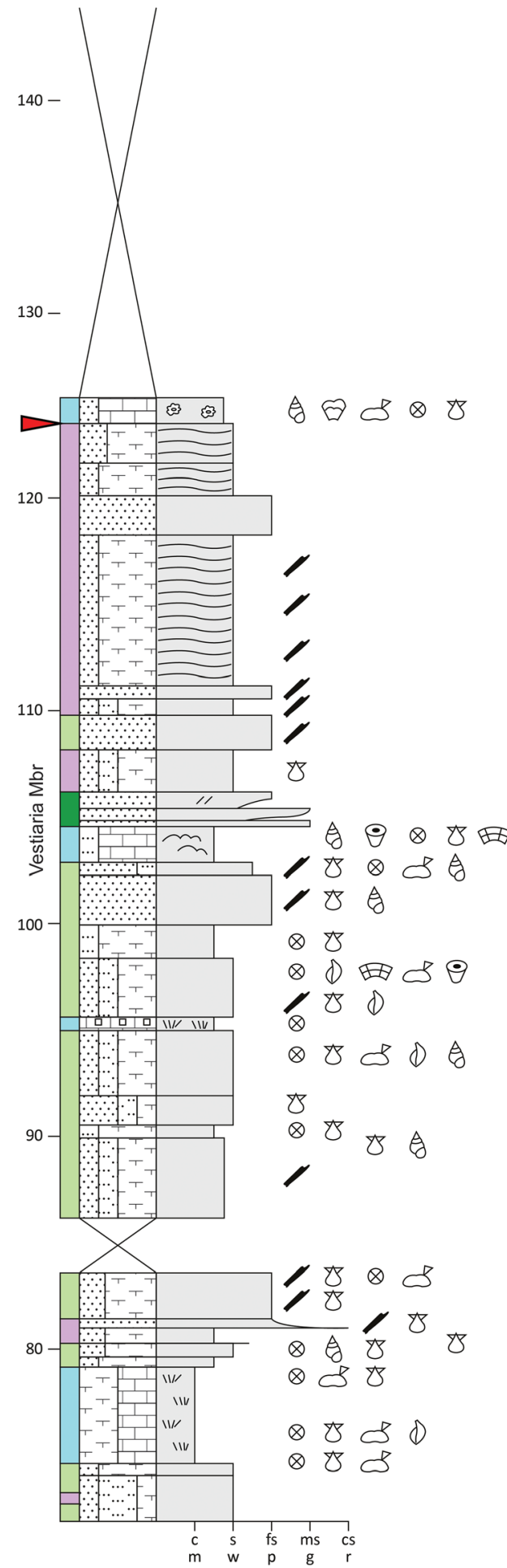

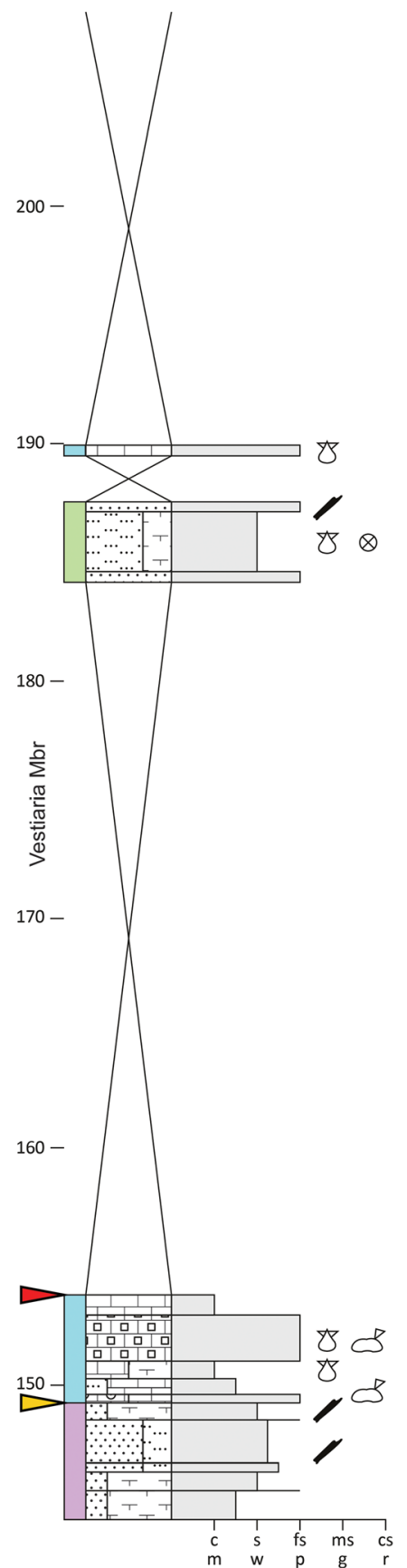

Fig. 12 Schematic log of the Vestiaria section (VES). See Fig. 8 for the key of symbols

sandstone with an erosional base, which is regarded as the basal bed of the Lourinhã Formation.

Interpretation: Similar to other sections, the Vestiaria section shows interbedded shallow shelf, brackish lagoon, freshwater lagoon and floodplain deposits. The coastal plain must have been very flat and low-lying so that even small-scale sea-level fluctuations, probably mostly driven by diapirism, could produce marked changes in facies. 

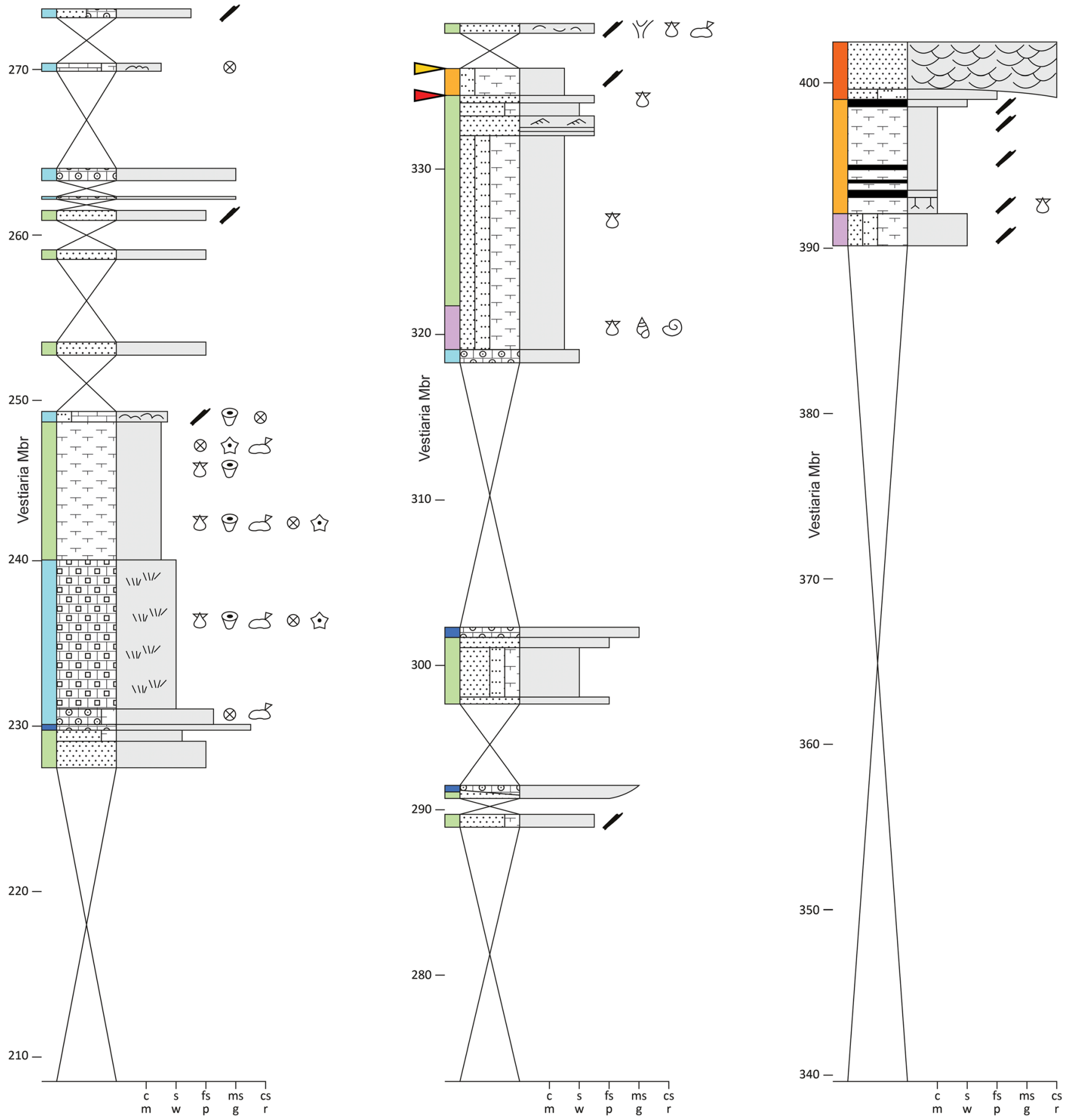

Fig. 12 (continued)

Fonte Santa (FON; Fig. 13)

Exposure and contacts: The Fonte Santa section is an only 106-m-thick road section and has several gaps (66\% exposure), which most likely represent fine-grained siliciclastic strata. The succession is assigned to the Vestiaria Member (see Appendix). The basal contact of the Alcobaça Formation with the underlying Montejunto Formation is sharp and potentially represents a paraconformity. The top of the Alcobaça Formation is not exposed.

Characteristics: While the lower third of the section is composed of carbonate rocks (mainly bioclastic wackestones, more rarely bioclastic-intraclastic grainstones and bioclastic packstones), the middle part is dominated by fine-grained 


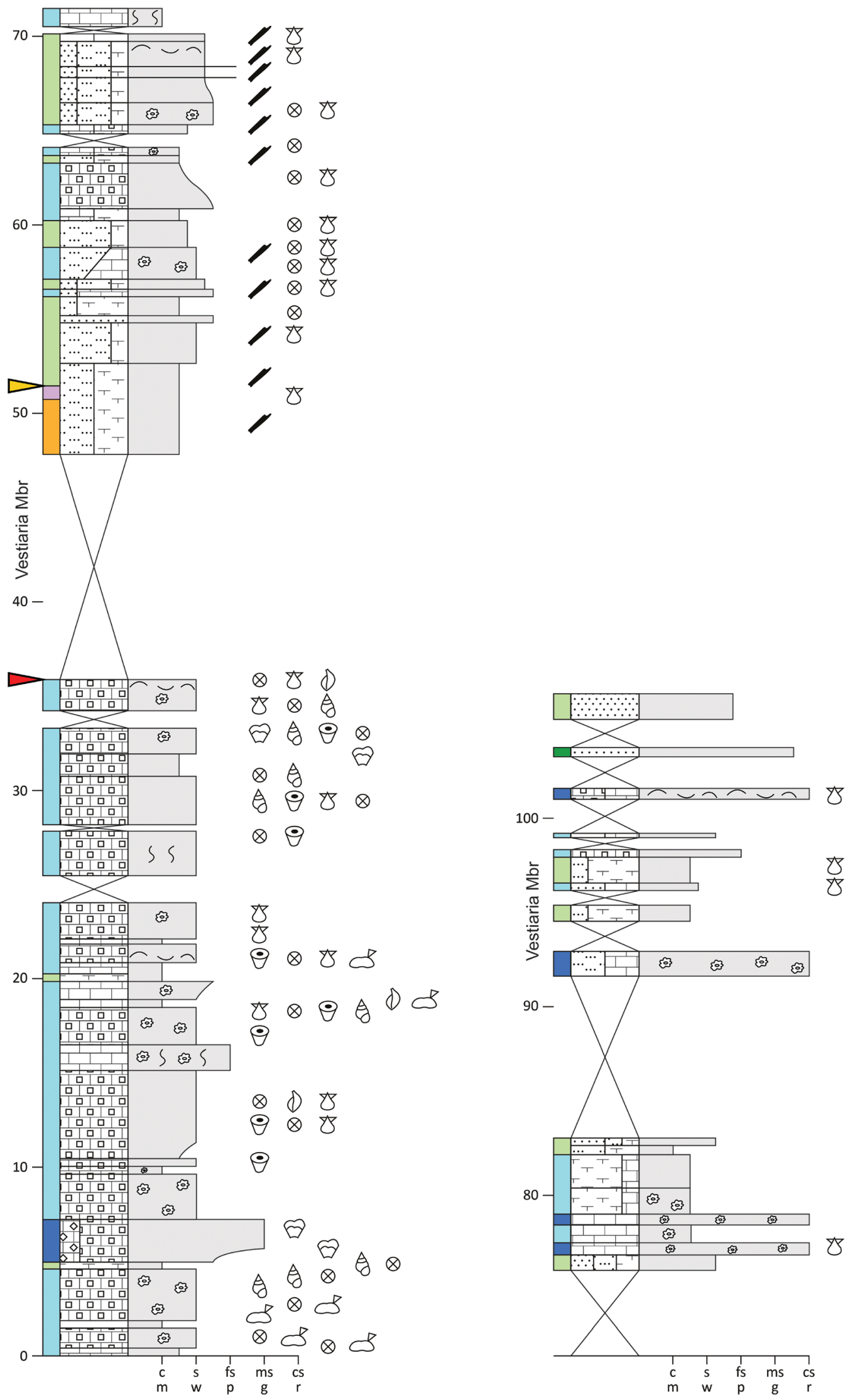

Fig. 13 Schematic log of the Fonte Santa section (FON). See Fig. 8 for the key of symbols 

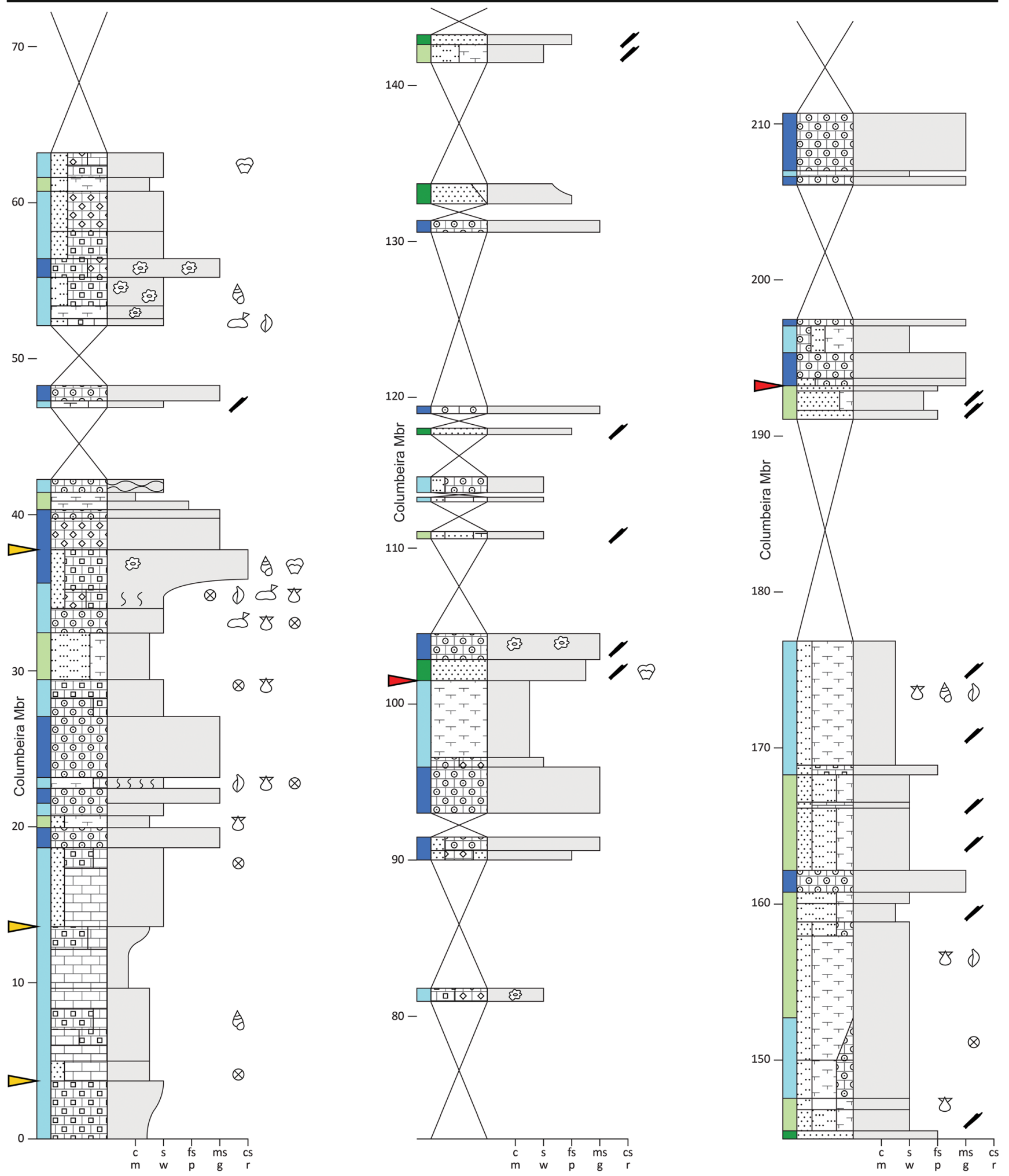

Fig. 14 Schematic log of the Columbeira section (COL). See Fig. 8 for the key of symbols

siliciclastic sediments (marly silt and marly fine-sandy silt with lignite pieces), and the upper third is an alternation of carbonate deposits (oncoidal and bioclastic rudstones, bioclastic packstones and calcareous marlstones) and finegrained sandstones (Fig. 13). Oncoids are very common, as are corals, bivalves, sponges, echinoids, brachiopods and red algae. Primary sedimentary structures are absent.

Interpretation: Sediments and benthic macrofauna point to fully marine environments characterised by low to moderate 


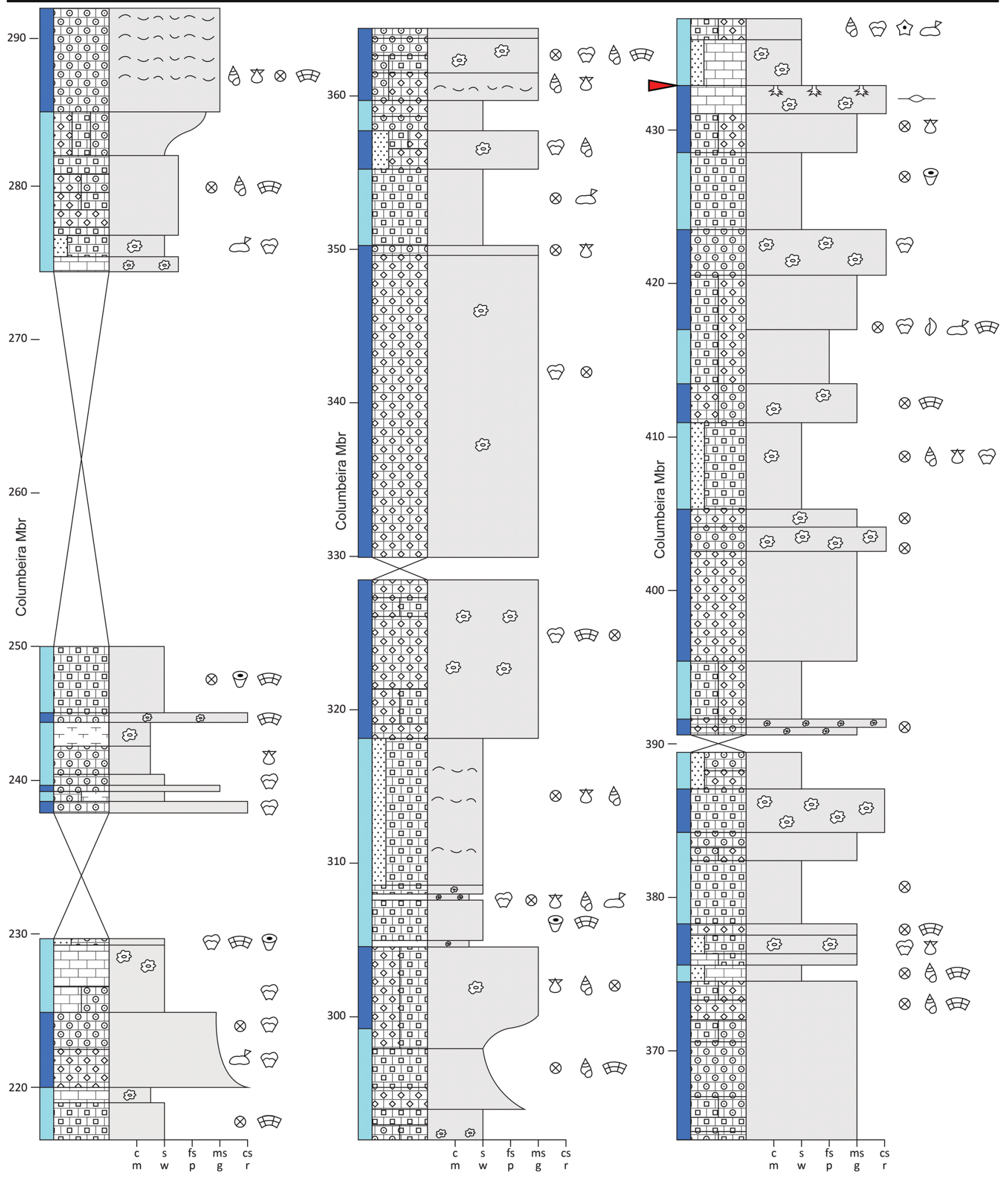

Fig. 14 (continued)

water energy. The few oncoidal rudstone layers most likely represent reworked lagoonal deposits. Environmental fluctuations are mainly expressed in the varying amounts of siliciclastic input, which may be climate related or moderated by diapiric activity.
Columbeira (COL; Fig. 14)

Exposure and contacts: The Columbeira section is a $577-\mathrm{m}-$ thick road section with a total exposure of $68 \%$. The carbonate-dominated succession forms the type locality of 

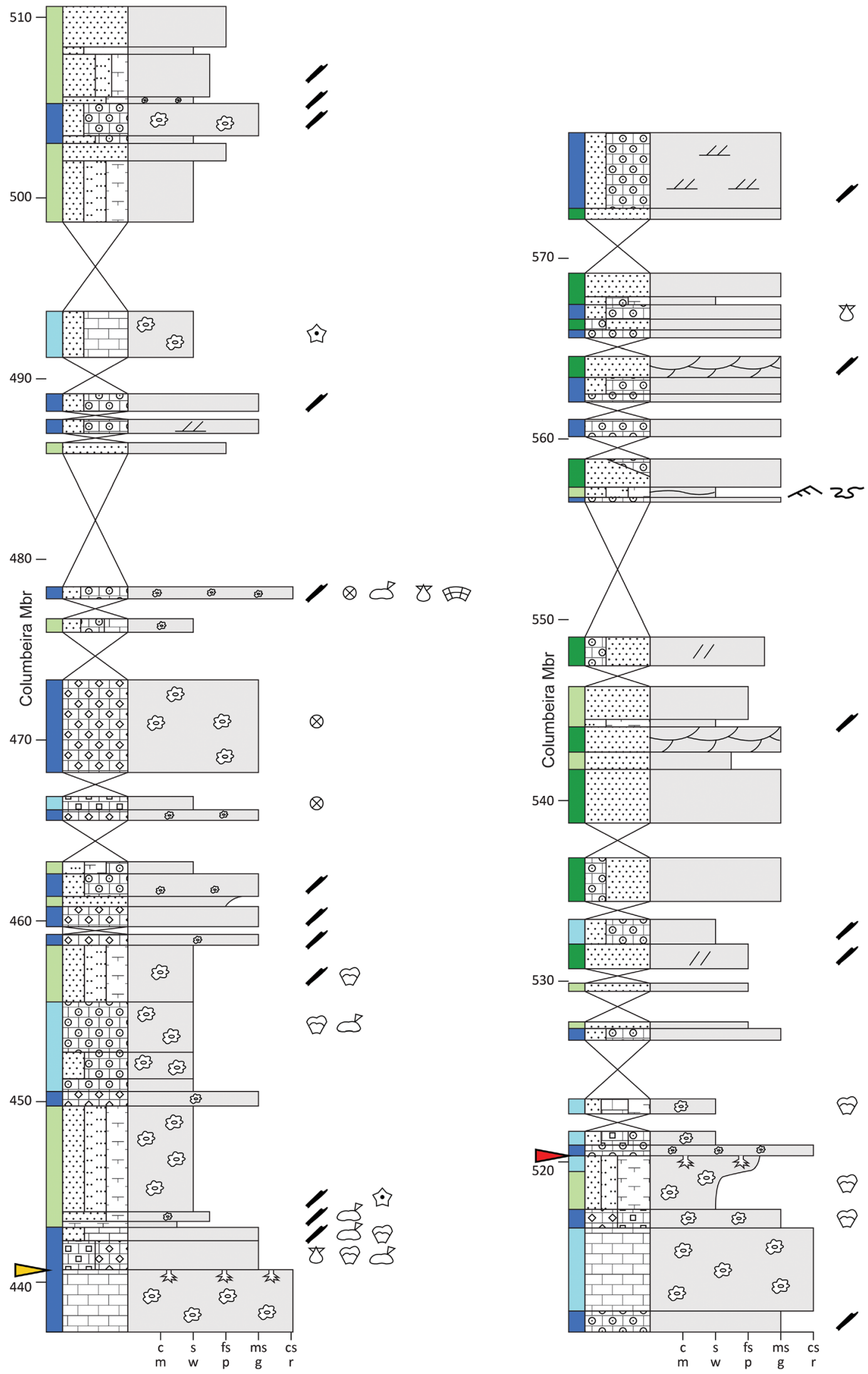

Fig. 14 (continued) 
the Columbeira Member (see Appendix). Base and top of the Alcobaça Formation are not exposed.

Characteristics: Although the Columbeira section is generally carbonate dominated, siliciclastic input is evident in two intervals at the base (0-193 m) and the top (442-577 m). In the first $200 \mathrm{~m}$, siliciclastic sediments are mainly fine grained (silty marl to marly silt, oncoid-bearing sandy marly silt), but in the uppermost $40 \mathrm{~m}$ (from $529 \mathrm{~m}$ upward), fine- to mediumgrained sandstones, partly trough or planar cross-stratified, dominate (Fig. 14). Low-energy carbonate strata consist of mudstones, intraclastic or bioclastic wackestones and oncoidal floatstones; high-energy carbonate strata are represented by ooidal, bioclastic and intraclastic grainstones and oncoidal rudstones. Large covered intervals, some of them more than $20 \mathrm{~m}$ in thickness, probably correspond to soft, fine-grained mixed carbonate-siliciclastic rocks. In the carbonate beds, benthic macrofossils include corals, gastropods, bivalves, cidaroid spines, brachiopods, red algae, sponges and stromatoporoids. In the siliciclastic sediments, the macrobenthic abundance and diversity are lower and the assemblages are composed mainly of bivalves, gastropods, brachiopods, rare crinoid ossicles and echinoid spines. Lignite pieces are restricted to beds with a sizable fraction of siliciclastic components. Polyspecific shell concentrations occur at several levels within the carbonate deposits. Three levels (at $433 \mathrm{~m}, 441 \mathrm{~m}$ and $520 \mathrm{~m}$ ) show small dissolution cavities, indicative of brief subaerial phases.

Interpretation: The Columbeira section represents shallowwater environments recording numerous short-term alternations between high-energy and low-energy settings. The grainstones and rudstones can be interpreted as shoals and bars, the latter forming barriers, behind which low-energy lagoonal environments existed, in which oncoids flourished. Within the section, there is a distinct change in the input of siliciclastic material. In the lower part of the section, the siliciclastic input is largely restricted to clay- to silt-sized components. In the middle part, where high-energy platform carbonate strata predominate, it is negligible. In the top $130 \mathrm{~m}$, high-energy siliciclastic strata are common and point to increased input from a close-by source area, driven either by higher freshwater run-off or by increased diapiric activity. The microkarst levels at $433 \mathrm{~m}, 441 \mathrm{~m}$ and $520 \mathrm{~m}$ document repeated forced regressions, probably also related to salt tectonics.

Dagorda (DAG; Fig. 15)

Exposure and contacts: Only the lower $96 \mathrm{~m}$ of this 364$\mathrm{m}$-thick section are well exposed, whereas in the remaining part, only half of the strata are exposed $(60 \%$ total exposure). The covered intervals are probably soft and, to a large extent, may represent fine-grained mixed carbonate-siliciclastic rocks. The entire succession is assigned to the Columbeira Member. The basal contact of the Alcobaça Formation with the underlying dolomitic marls of the Dagorda Formation is tectonic. The contact to the overlying Lourinhã Formation is obscured.

Characteristics: Except for the interval from 57.5 to $90 \mathrm{~m}$ and the uppermost $8 \mathrm{~m}$, where fine- to medium-grained sandstones are fairly common, the succession is dominated by high-energy, partly large-scale trough cross-bedded carbonate strata such as ooidal, bioclastic and intraclastic grainstones (Fig. 15). Several of these beds also contain a certain percentage of sand and scattered oncoids, in addition to a diverse benthic macrobiota of stromatoporoids, red algae, gastropods, bivalves, corals and echinoids. Lignite pieces are comparatively rare. Low-energy carbonate deposits are developed as oncoidal and bioclastic floatstones and bioclastic and intraclastic wackestones, which may contain variable percentages of sand. A coral biostrome occurs at $235 \mathrm{~m}$. The benthic macrofauna is less diverse than that in the high-energy carbonate beds. Low-energy siliciclastic sediments are represented by fine-grained sandstones, in several cases thinly interbedded with silty marl. Lignite pieces are common. Highenergy siliciclastic sediments consist of medium- to coarse-grained sandstones, several of which exhibit large-scale cross-stratification. They occur in relatively widely spaced intervals, often contain a small percentage of ooids and are overlain by ooidal grainstones. The most prominent example is a 5-m-thick cross-bedded ooidbearing coarse-grained sandstone at $84.5 \mathrm{~m}$.

Interpretation: The Dagorda section, dominated by highenergy carbonate strata, depicts fully marine, very shallow environments that were, to a large extent, situated above the fair-weather wave-base. Micritic beds, in turn, were deposited in marine lagoons behind ooidal, intraclastic or bioclastic bars. The intermittently introduced siliciclastic material commonly became subsequently mixed with the carbonate matrix. This points to a close source area. Input of sand is short lived and periodic, marking events of high surface run-off and/or diapiric activity.

Sobral da Lagoa (SOB; Fig. 16)

Exposure and contacts: The Sobral da Lagoa section comprises $242 \mathrm{~m}$ of sediments, which are assigned to the Columbeira Member. Only the lower $100 \mathrm{~m}$ are well exposed (Fig. 7d); in the remaining part, exposed beds and covered intervals are equi-proportional (60\% total exposure). The basal contact of the Alcobaça Formation with 

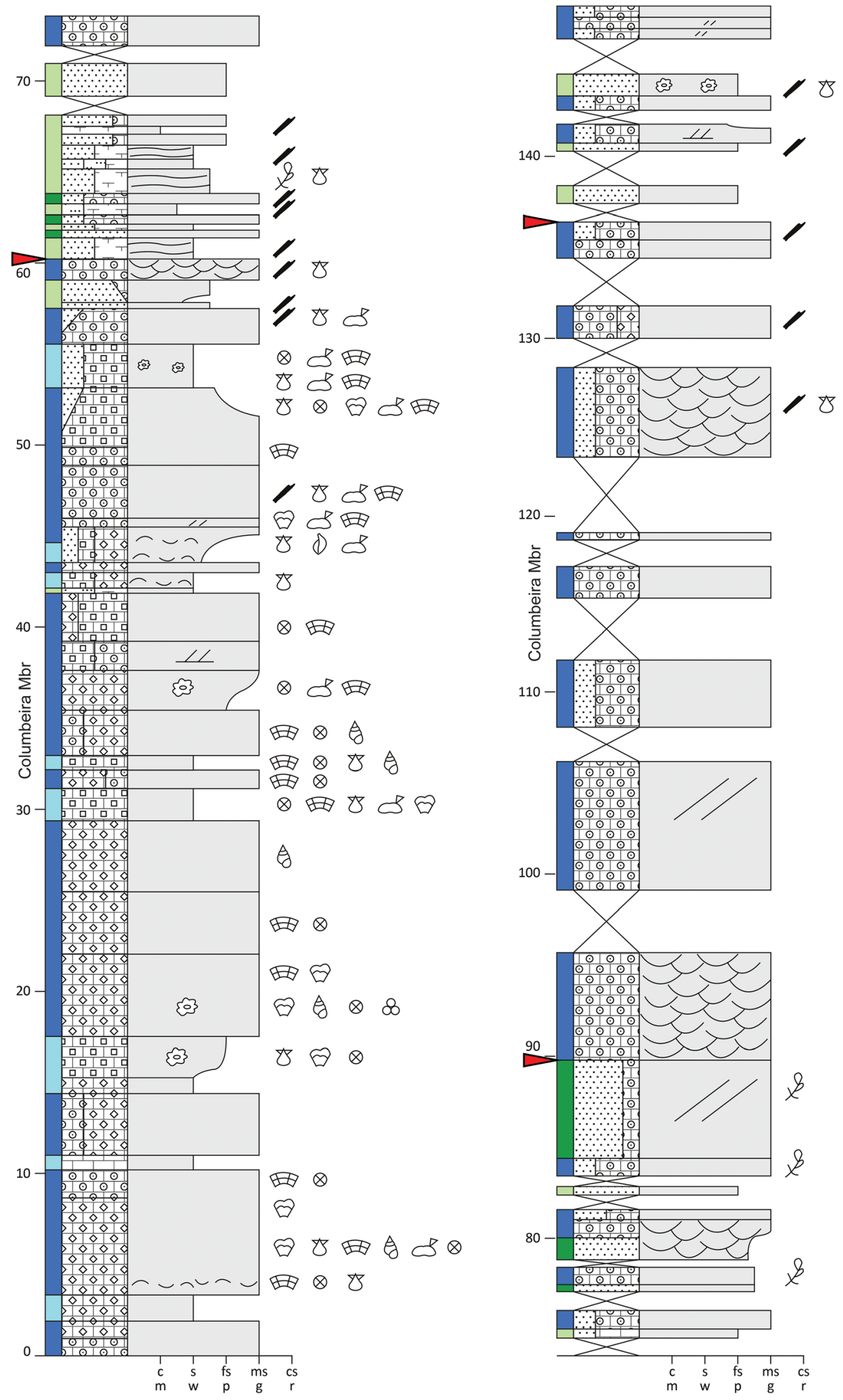

Fig. 15 Schematic log of the Dagorda section (DAG). See Fig. 8 for the key of symbols 

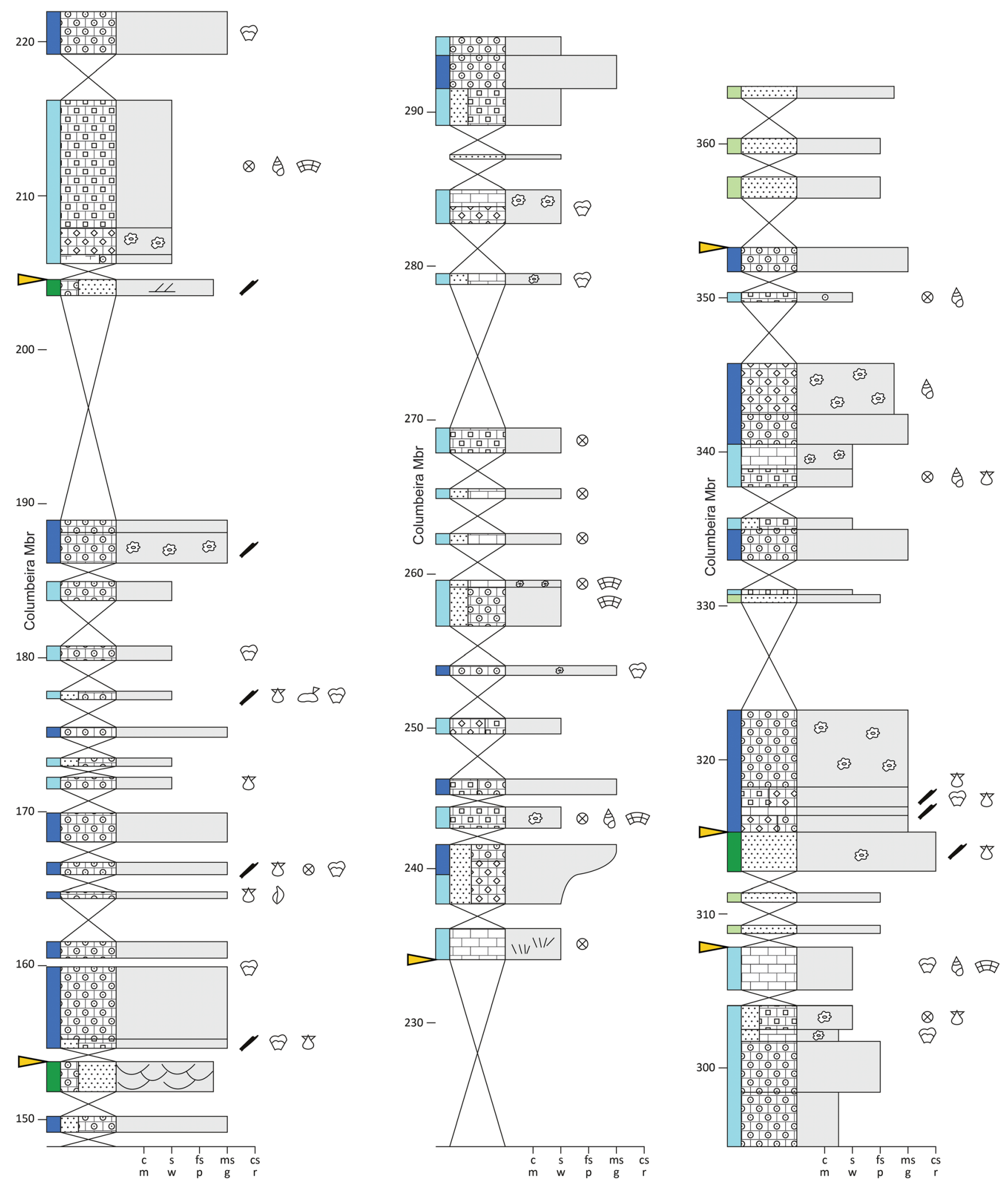

Fig. 15 (continued) 
the underlying Middle Jurassic carbonate beds is tectonic, but not exposed. The contact to the overlying Lourinhã Formation is also obscured.

Characteristics: The lower $100 \mathrm{~m}$ of the succession consist of carbonate deposits with very minor sand-prone carbonate intervals. Low-energy carbonate rocks dominate (intraclastic and bioclastic wackestones, occasionally also carbonate mudstones, intraclastic or ooidal grainstones and rarely oncoidal rudstones). Scattered lignite pieces occur, as do oncoids. Black pebbles are encountered at six levels (at $3 \mathrm{~m}, 11 \mathrm{~m}, 34 \mathrm{~m}, 36 \mathrm{~m}$, $48 \mathrm{~m}$ and $80 \mathrm{~m}$ ), usually associated with microkarst features. Benthic macrofauna is represented by gastropods, bivalves, stromatoporoids, corals and echinoids. The trace fossil Thalassinoides is comparatively rare. Four metres above the base, a sandy carbonate mudstone exhibits dinosaur footprints (Fig. 7d). From 110 to $152 \mathrm{~m}$, fine-sandy siltstones and sandy ooidal packstones are the dominant exposed lithologies. The remaining section consists mainly of high-energy carbonate strata (sandy to silty ooidal grainstones), but some marl and fine-sandy marl intercalations also occur. Plant debris are common in the uppermost $60 \mathrm{~m}$, and another level with black pebbles is found at $227 \mathrm{~m}$.

Interpretation: The section records marine deposition throughout, as demonstrated by the fauna. However, the environments appear to have been mostly very shallow and nearshore, as is indicated by the dinosaur tracks, numerous levels with dissolution cavities indicating emergence and black pebbles that have been eroded from close-by subaerially exposed areas (e.g. Leinfelder 1987). These beds document forced regressions, likely related to salt tectonics or climatic fluctuations.

\section{Amoreira (AMO; Fig. 17)}

Exposure and contacts: The 206-m-thick Amoreira section is an only intermittently exposed (36\% of total thickness) road section, assigned to the Columbeira Member. The covered intervals most likely correspond to soft marly/silty horizons. The basal contact of the Alcobaça Formation with the underlying dolomitic marls of the Dagorda Formation is tectonic, but not exposed. The contact to the overlying Lourinhã Formation is also obscured.

Characteristics: The exposed section starts with high-energy (oncoidal-intraclastic grainstones, oncoidal-ooidal grainstones) and low-energy (mudstones, bioclastic or ooidal wackestones, intraclastic packstones) carbonate deposits, occasionally with an admixture of fine quartz grains. Towards the top, the proportion of siliciclastic rocks increases. These are represented by fine- to coarse-grained sandstones and, at the top, by several metres of sandy marly siltstones (Fig. 17). The high-energy carbonate and siliciclastic strata commonly exhibit large-scale trough or planar cross-stratification. In the carbonate beds, stromatoporoids, red algae, corals and gastropods are the dominant fossils, whereas in the siliciclastic sediments, bivalves prevail.

Interpretation: The section represents fully marine, shallowwater, nearshore environments, situated partly above and partly below the fair-weather wave-base. Dissolution cavities in the basal biograinstones are evidence of a brief subaerial phase. Several beds with black pebbles and common lignite pieces indicate the proximity to land areas and, together with short-lived events of increased input of sand, document environmental fluctuations driven by dynamic diapirism and/or climate.

\section{Biofacies associations and palaeoenvironments}

A schematic overview of the biofacies of the Alcobaça Formation and their characteristics is provided in Table 1.

Floodplain with overbank deposits (BA1)

Features: This biofacies association dominates in the coastal cliffs north and south of São Martinho do Porto (SAO and SAL sections; Figs. 9, 10 and 18h). The prevalent rock colour is red, but purplish, turquoise and violet colours are also present. The generally finegrained sediments are poorly sorted, consisting mainly of a mixture of clay and silt with varying admixtures of micaceous fine sand and carbonate. Scattered, cm-sized caliche nodules are very widespread. Thin, laterally continuous calcrete layers are rare (Fig. 19g). The finegrained sediments are punctuated by thin siltstone and sandstone intercalations that exhibit ripple lamination, rarely parallel lamination and, in some cases, convolute bedding, likely related to dewatering. Caliche nodules are commonly concentrated at the usually sharp bases of such intercalations. Rarely, rootlet traces are preserved in the sandstone intercalations. In addition, desiccation cracks occur in several beds. Interlayered bedding is occasionally present. Scoyenia is the only trace fossil present; body fossils are absent.

Interpretation: The fine-grained sediments represent floodplain deposits; the red colour and the abundant pedogenic carbonate facies point to a semi-arid climate (e.g. McPherson 1979; Rao 1990). The coarser 

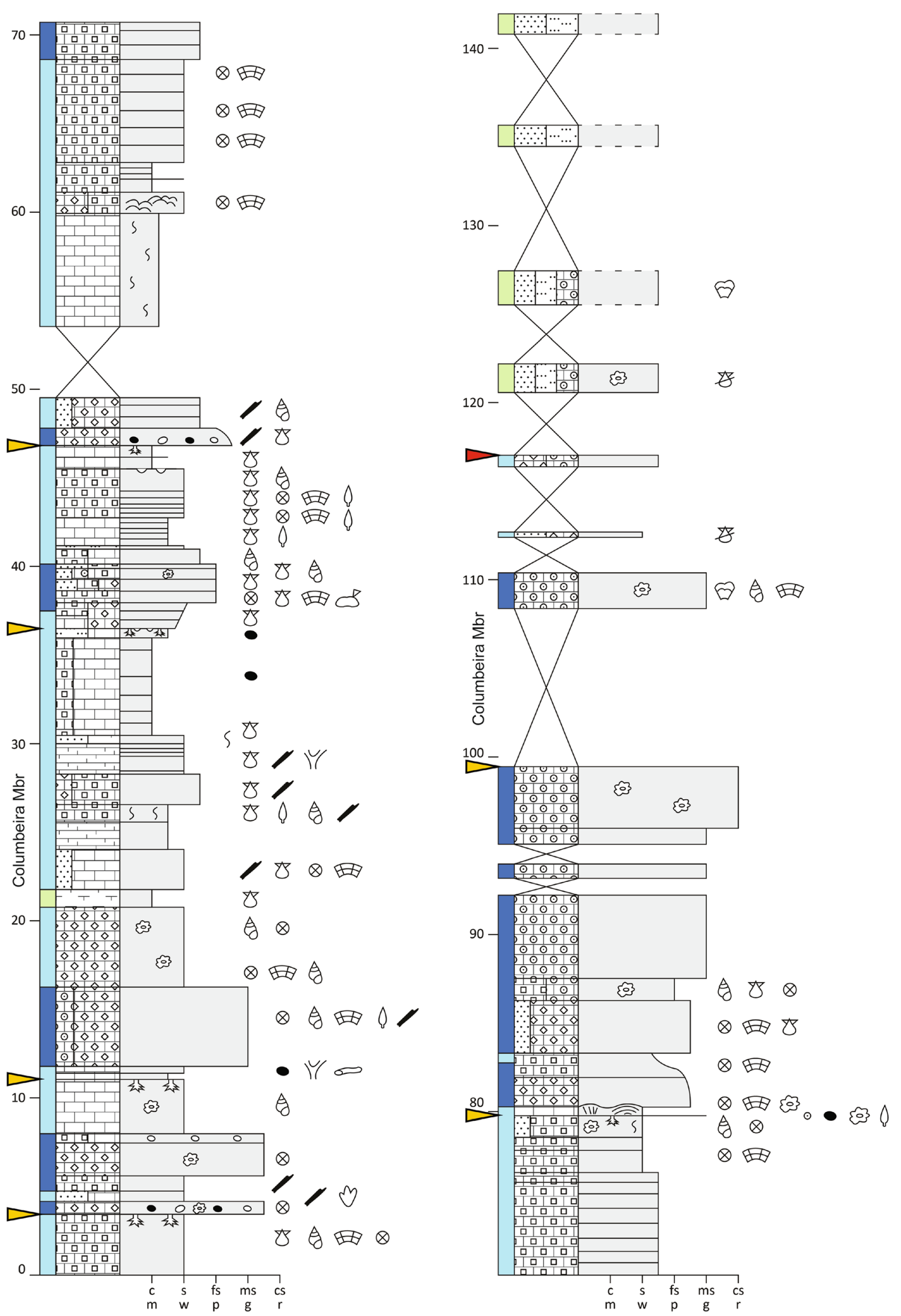

Fig. 16 Schematic log of the Sobral da Lagoa section (SOB). See Fig. 8 for the key of symbols 

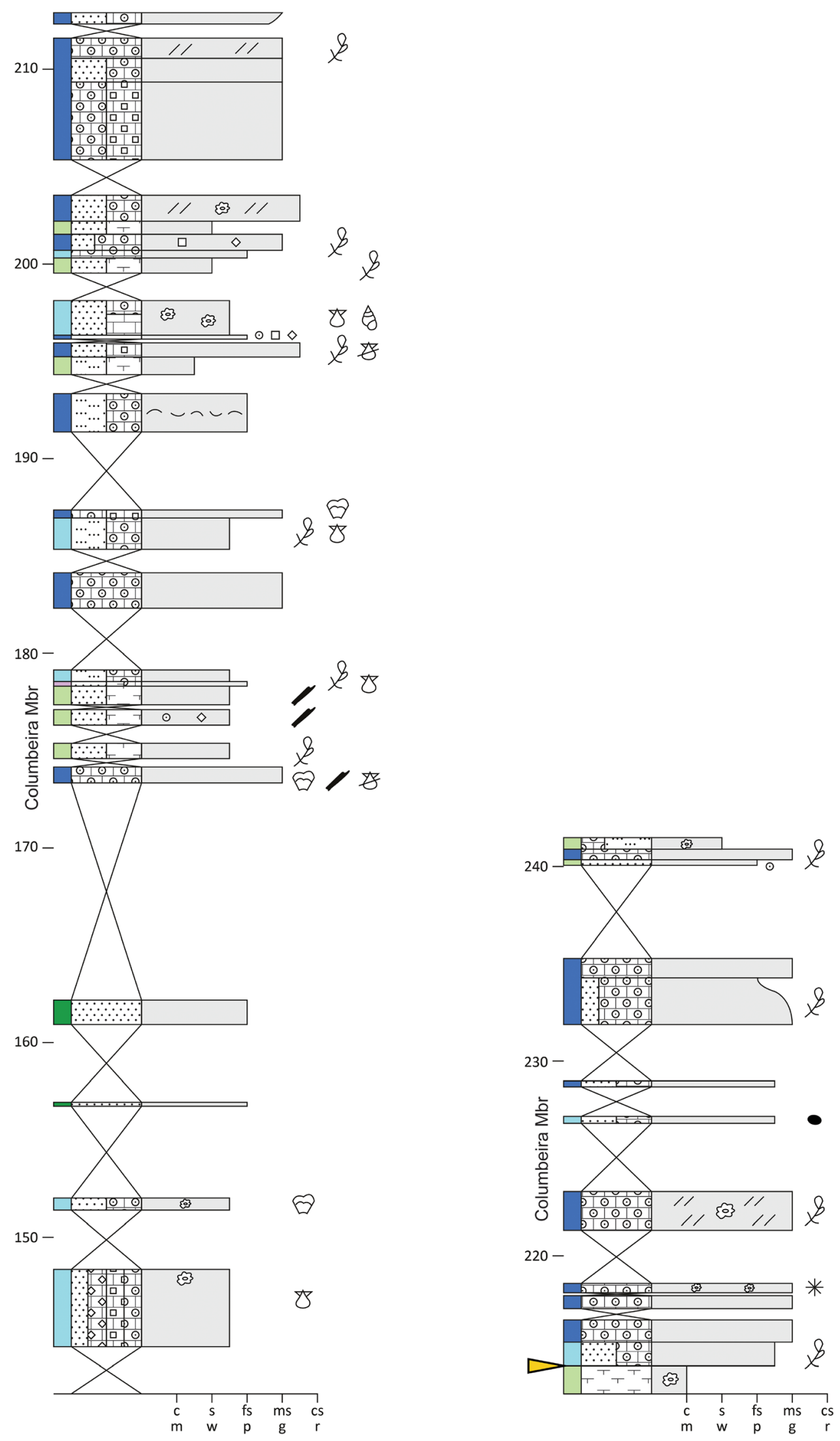

Fig. 16 continued. 


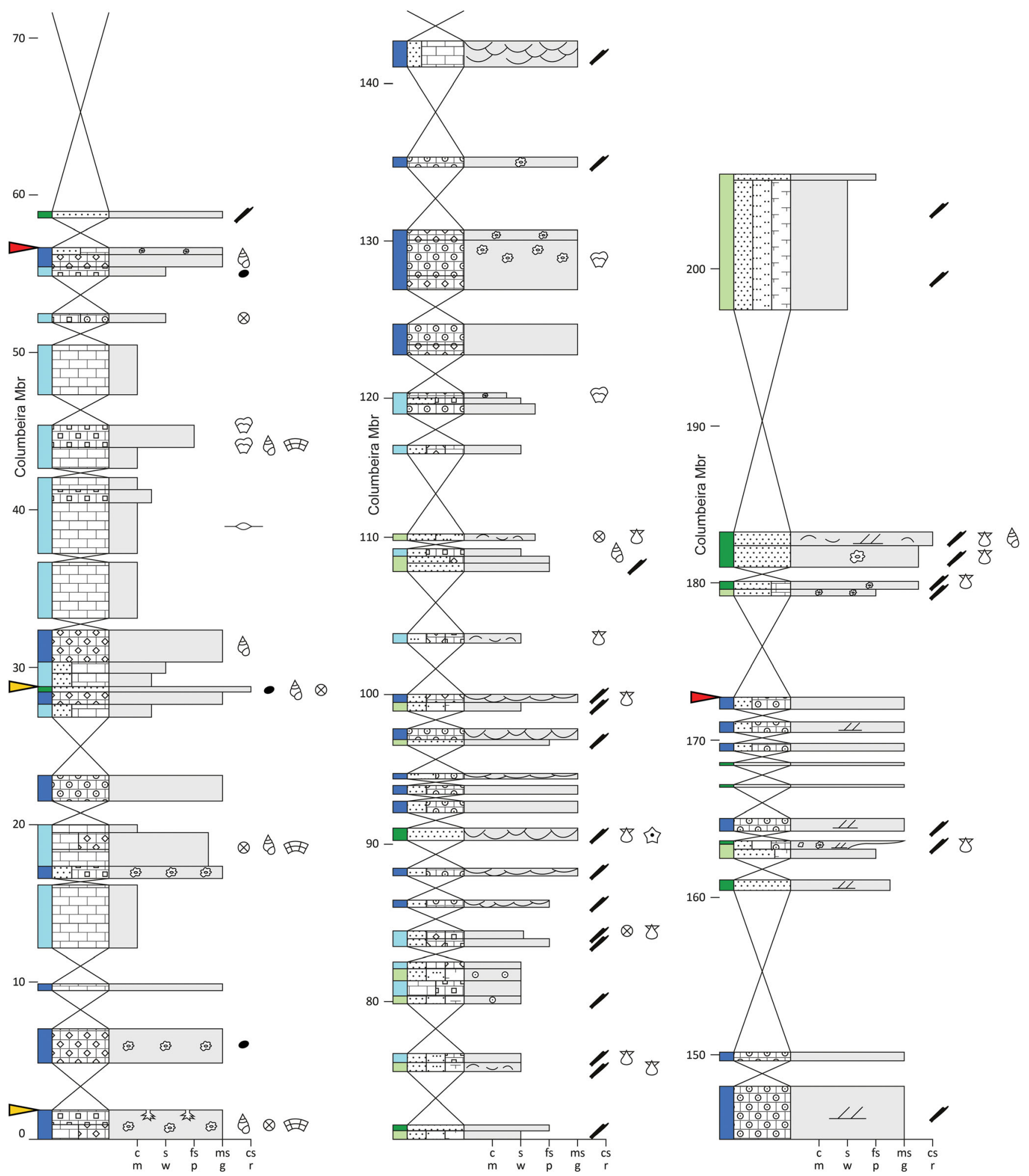

Fig. 17 Schematic log of the Amoreira section (AMO). See Fig. 8 for the key of symbols 


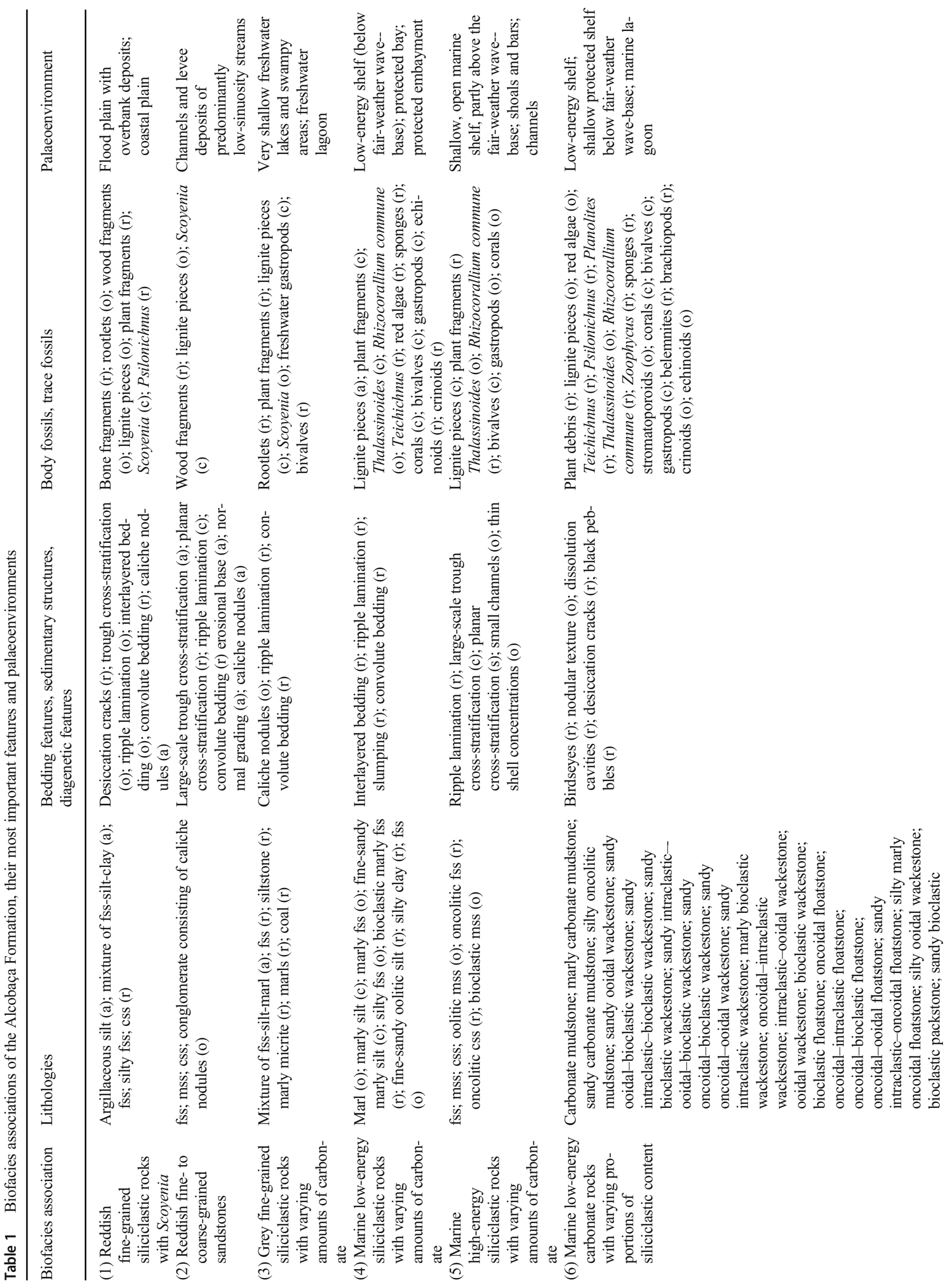




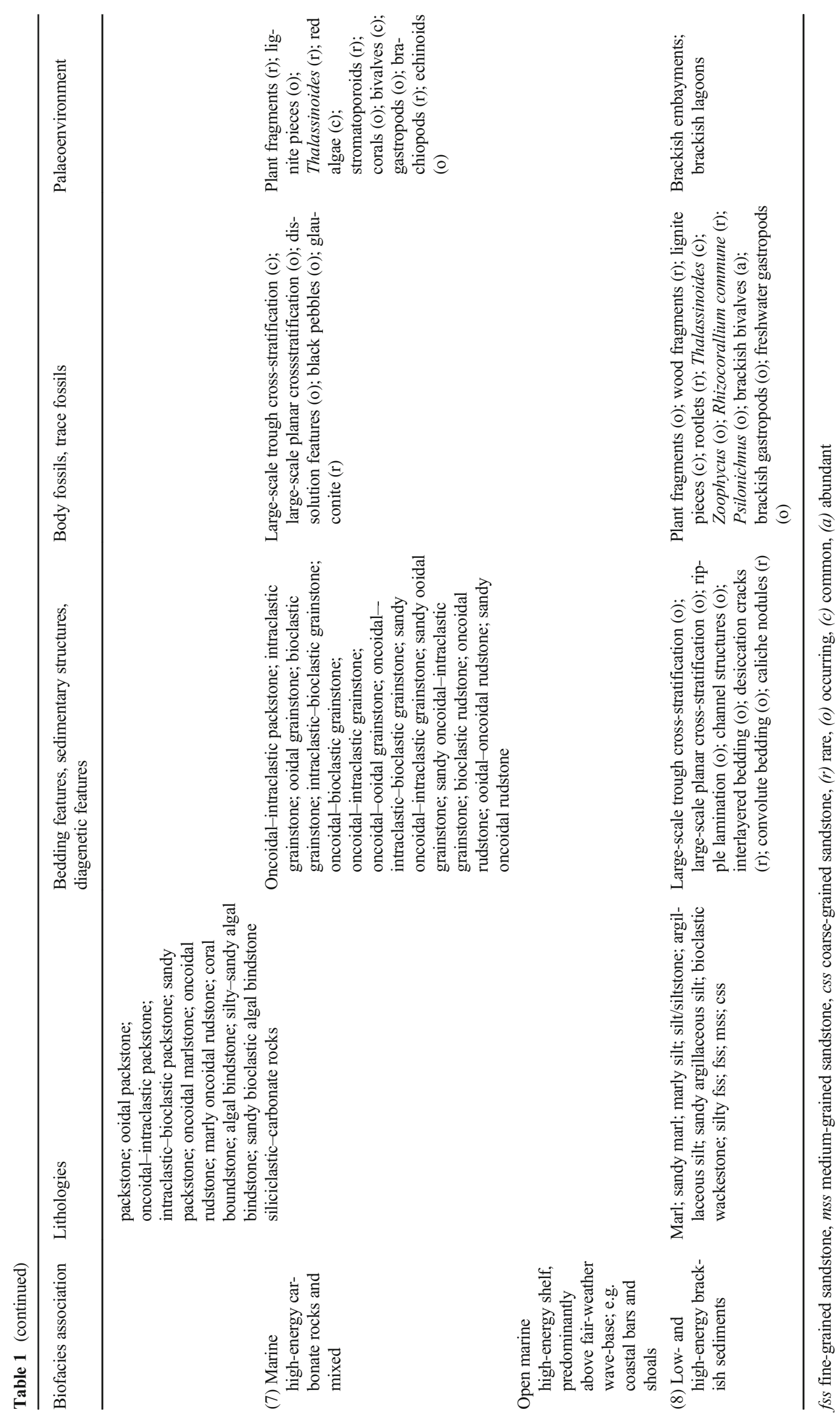



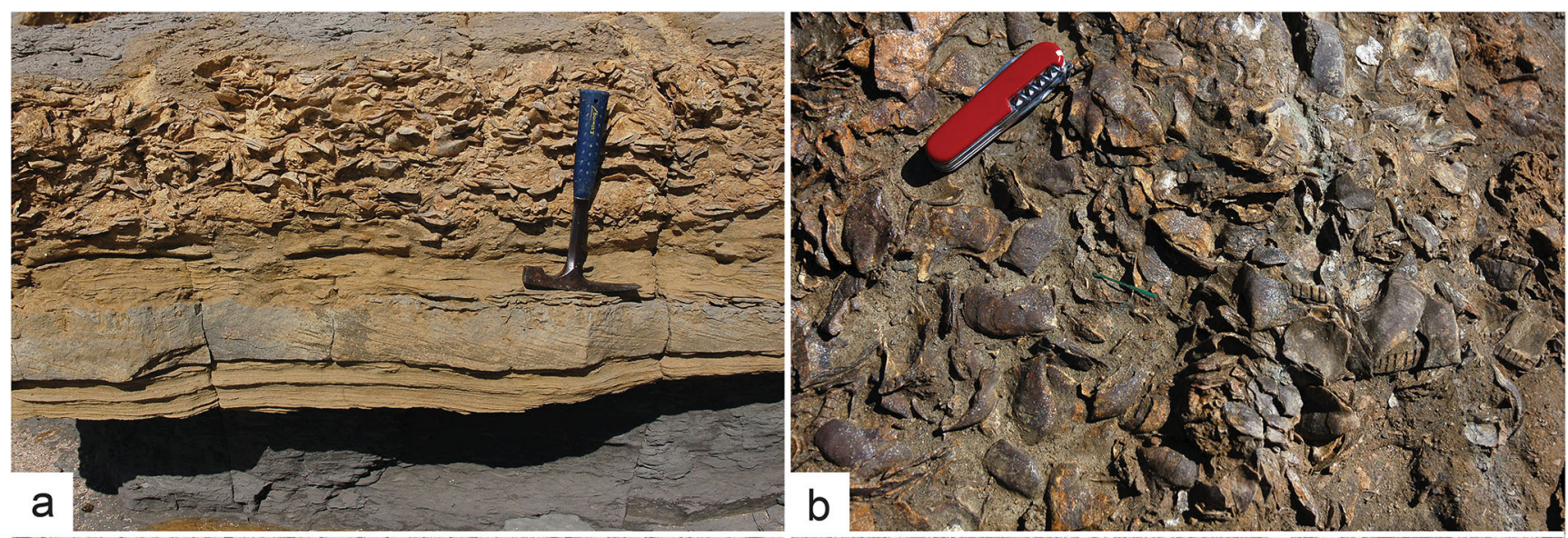

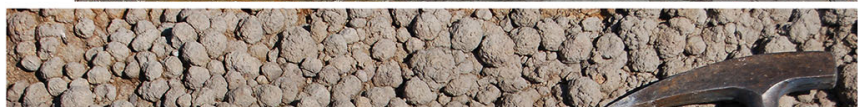

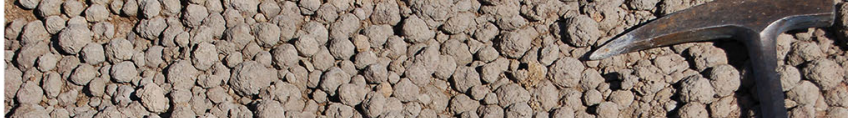

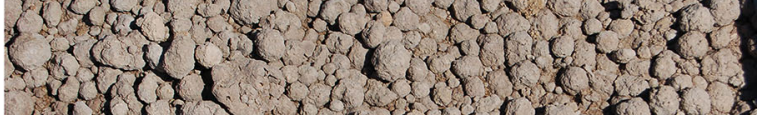

If सf E -

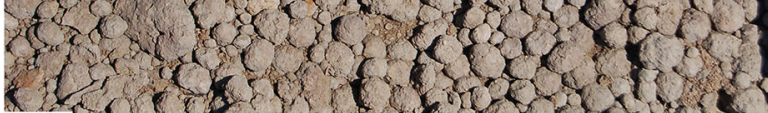

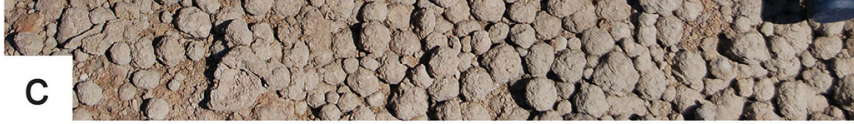

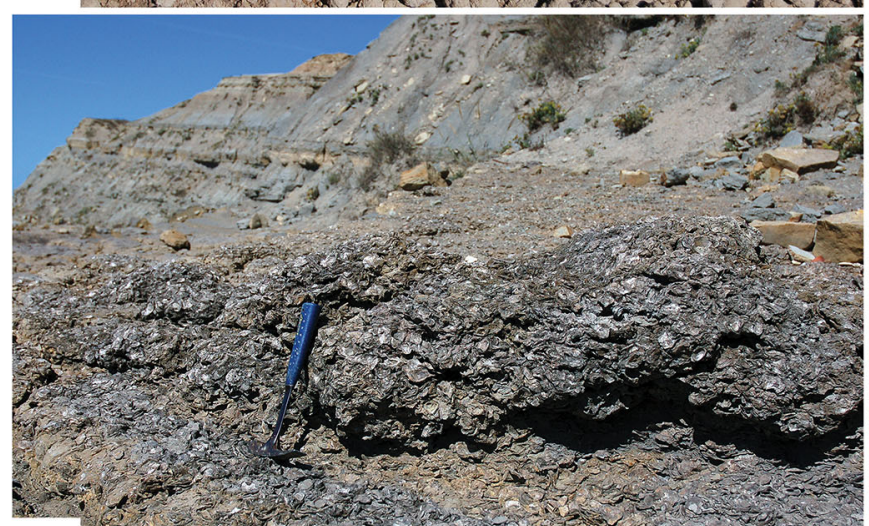

e

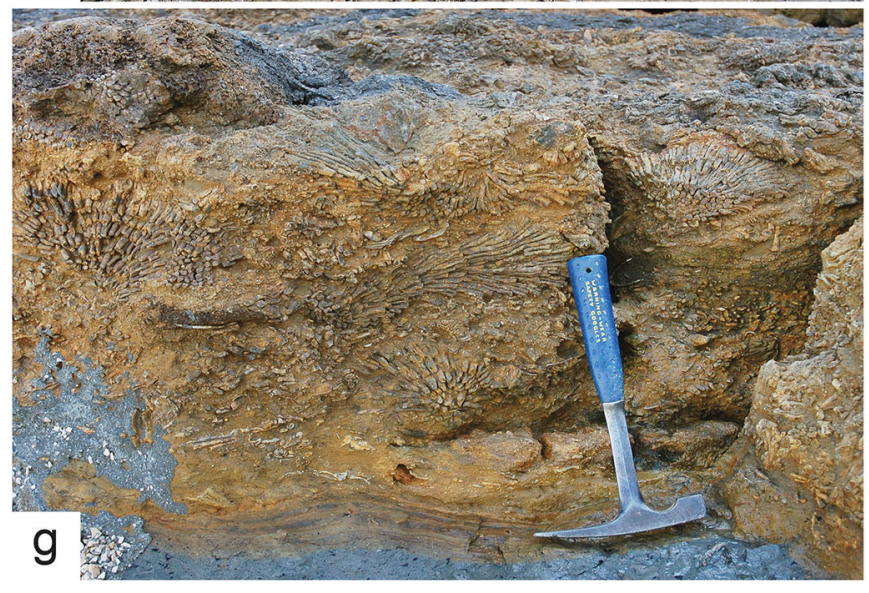

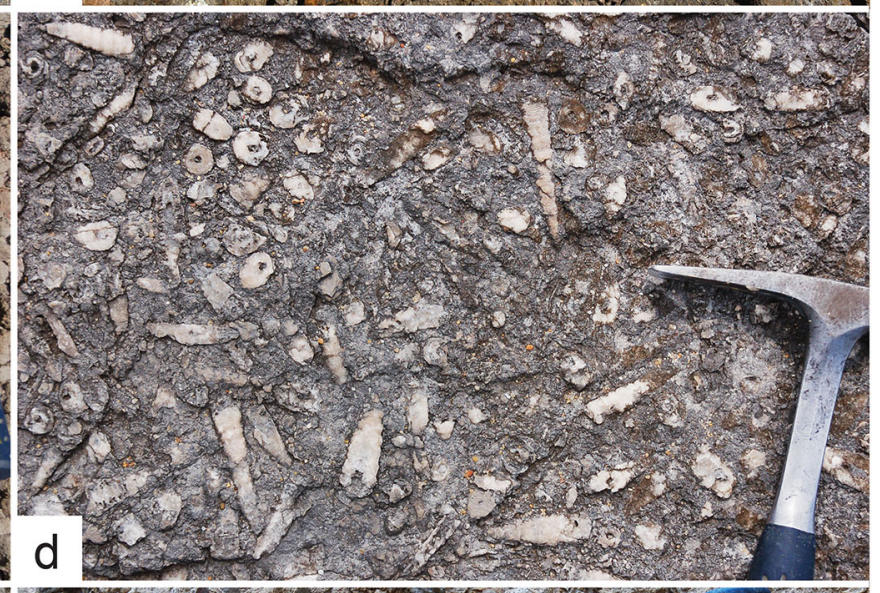
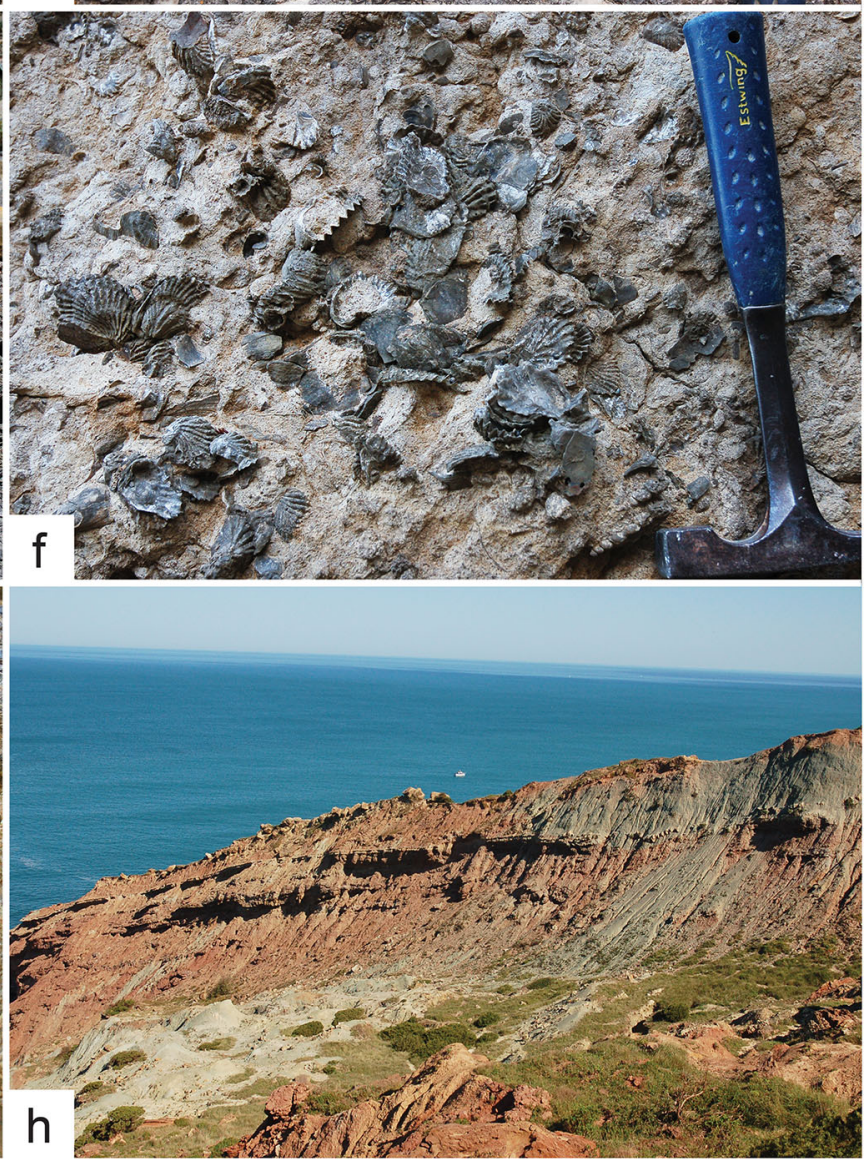
Fig. 18 Outcrop features of the Alcobaça Formation. a Alaperna polita-Pteria credneriana shell bed resting on cross-bedded sandstone; Consolação Mbr; Consolação section, 94 m. b Alaperna polita shell bed, bedding plane view; Consolação Mbr; Consolação section, $74 \mathrm{~m}$. c Oncoid rudstone, bedding plane view; Salgado Mbr; São Martinho do Porto section, $578 \mathrm{~m}$. d Nerineoidea-rich bioclast floatstone, bedding plane view; Salgado Mbr; São Martinho do Porto section, $576 \mathrm{~m}$. e Low-diversity oyster patch reef dominated by Praeexogyra pustulosa; Consolação Mbr; Consolação section, $133 \mathrm{~m}$. f Loosely packed Actinostreon gregareum shell bed, bedding plane view; São Martinho Mbr; São Martinho do Porto section, $52 \mathrm{~m}$. g Coral meadow dominated by Calamophylliopsis partly preserved in growth position; Consolação Mbr; Consolação section, $6 \mathrm{~m}$. h Reddish silty floodplain deposits grade upwards into offset lateral accretion packages, truncated by a thin overbank/ channel margin sheet sandstone; Gralha Mbr; São Martinho do Porto section, Facho promontory

intercalations are crevasse splay deposits, an interpretation supported by their sharp bases and normal grading. The rare rootlet horizons may correspond to vegetated areas of the floodplain during brief time intervals of higher humidity. Such red beds also occur, albeit not as extensive, in other parts of the Lusitanian Basin, for example in the Sobral member of the Farta Pao Formation (sensu Schneider et al. 2009) at Santa Cruz (Fürsich 1981a). Occasional marine or brackish intercalations suggest that the sediments formed on an extensive coastal plain bordered by lagoons and brackish bays.

\section{Fluvial channel fills (BA2)}

Features: Varicoloured, but mainly reddish fine- to coarsegrained, occasionally conglomeratic, arkosic sandstones, ranging from a few decimetres to approximately $3 \mathrm{~m}$ in thickness, occur intercalated between the floodplain biofacies (BA1; Fig. 18h). Their base is invariably sharp and often erosional, cutting into the underlying finegrained sediments. Some of the sandstones are lenticular, others are laterally continuous. The base is commonly conglomeratic and consists of reworked caliche nodules. In several cases, intraformational sandstone or siltstone pebbles and, in a single case, quartz pebbles are present. Sandstones often fine upward. Sedimentary structures include large-scale trough cross-stratification, rarely planar cross-stratification, ripple cross-lamination and, in the upper part, convolute bedding and, more rarely, finely interlayered bedding. In a single case (SAL section at 250 m; Fig. 10), several channels form an amalgamated unit. Small lignite pieces are occasionally concentrated at the base, and fine plant debris covers some foresets. Scoyenia is a common trace fossil in the finer-grained upper levels. The only body fossils are rare bone fragments.
Interpretation: Given that gravel bars as well as point bars are absent, the sandstone bodies represent the fills of small, presumably mainly straight-headed to slightly meandering streams, which crossed the floodplain. Conglomeratic channel lags with caliche nodules are indicative of meandering or sweeping low-gradient settings, which cannibalised pedogenic overbank floodplain facies. Rare planar cross-bedded sandstones are interpreted as small sand bars. Levee deposits are represented by the finer-grained top parts of many of the packages, which occasionally exhibit interlayered bedding (cf. Miall 1996).

\section{Lake deposits (BA3)}

Features: Lake deposits are mainly grey to greenish grey and are dominated by fine-sandy, marly silt. Rarely they consist of calcareous marl and occur intercalated between floodplain deposits of the coastal sections. Generally, they are only a few metres thick but may extend for more than $60 \mathrm{~m}$ in the São Martinho do Porto section (from 456 to 520 m; Fig. 9). They commonly contain scattered caliche nodules, plant fragments, lignite pieces and, in one case, wood fragments up to $1 \mathrm{~m}$ in length. Rootlet horizons are rare. A several-metres-thick succession of cross-bedded fine- and medium-grained sandstones with Scoyenia occurs within the thick lacustrine succession mentioned above. Decimetre-thick coal layers, associated with rootlet horizons, have been encountered only at the top of the Vestiaria section (Fig. 12 at 393-398 m).

Poorly preserved unionid bivalves and gastropods (e.g. Ptychostylus, Amplovalvata, Planorbis), fish scales, ostracods (e.g. Theriosynoecum, Bisulcocypris) and charophyte gyrogonites occur and locally are common (Fig. 20d, e).

Interpretation: The fine-grained sediments differ from floodplain deposits by their grey colour and fossil content. The freshwater molluscan and ostracod fauna indicates lacustrine environments of deposition. Their limited vertical extent suggests deposition in small, shallow lakes and, in some cases, also in freshwater lagoons. Rootlets, as well as the coal layers associated with lignite-rich marl at Vestiaria, denote swampy areas at the lake margins, or gradual drying of the lakes. The thick lake sediment interval in the São Martinho do Porto section most likely represents a larger lake. The coarseningupward siltstone-sandstone package occurring in this succession corresponds to a small delta complex with delta-front sediments and a distributary channel.

Low-energy siliciclastic to mixed carbonate-siliciclastic open shelf deposits (BA4)

Features: As is commonly the case in the geological record (e.g. Lomando and Harris 1991), many of the lithologies in 

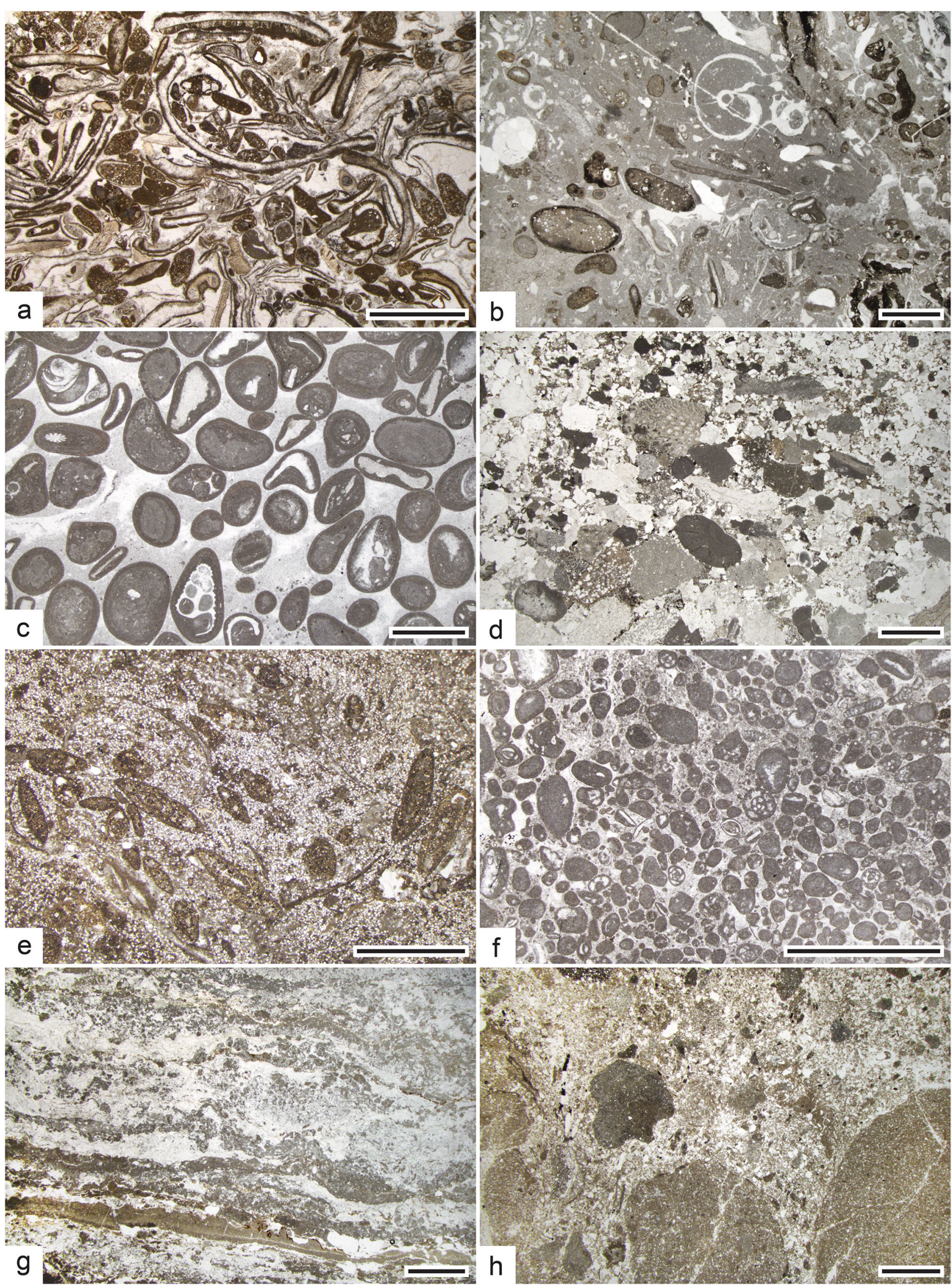

$10 \mathrm{k}$ )

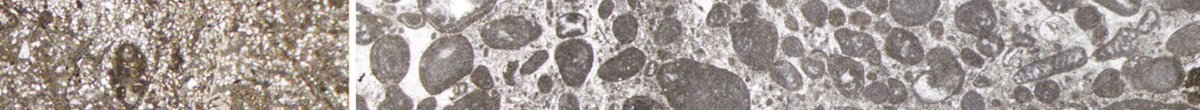

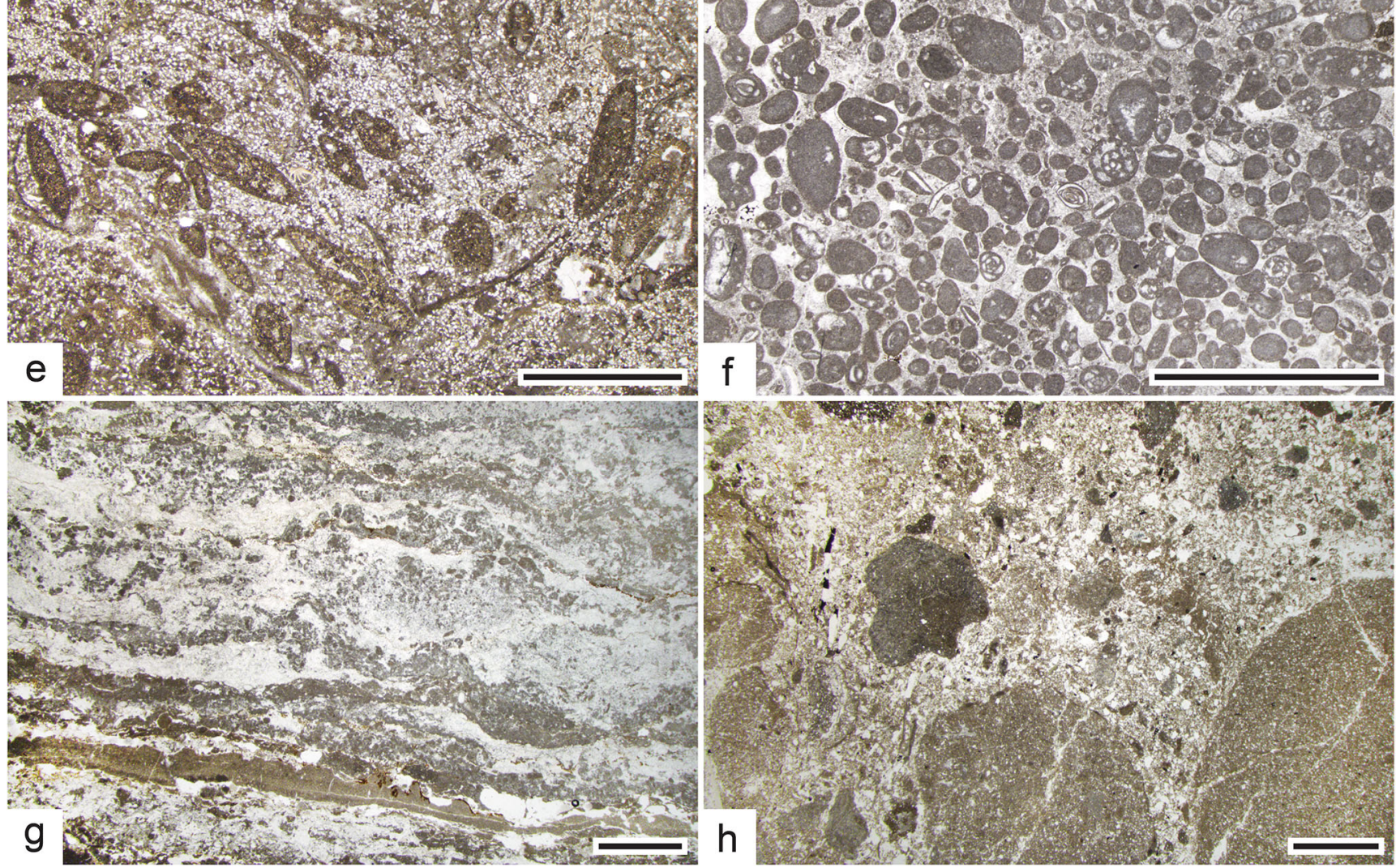


Fig. 19 Typical microfacies of the Alcobaça Formation. a Intraclasticbioclastic rudstone with coated grains, lituolid foraminifera, gastropods and quartz; Salgado Mbr; São Martinho do Porto section, 578 m (A-4-8). b Bioclastic wackestone to floatstone; Vestiaria Mbr; Vestiaria section, $5 \mathrm{~m}$ (A-15-5). c Poorly winnowed oncoidal grainstone; predominant nuclei of oncoids are the red alga Marinella, echinoid spines and gastropods; Columbeira Mbr; Columbeira section, 239 m (A-28-87). d Medium- to coarse-grained sandstone with pebbles and bioclasts (e.g. Marinella, calcareous sponge); Vestiaria Mbr; Vestiaria section, $56 \mathrm{~m}$ (A-15-59). e Sandy siltstone with lituolids; Gralha Mbr; São Martinho do Porto section, $418 \mathrm{~m}$ (A-3-18). fOoidal-oncoidal grainstone with abundant lituolid and miliolid foraminifera; Columbeira Mbr; Amoreira section, $6 \mathrm{~m}$ (A-21-2). g Caliche with fenestral fabric; Gralha Mbr; São Martinho do Porto section, 555 m (A-3-97). h Polymict conglomeratic sandstone with algal debris and lignite; Gralha Mbr; São Martinho do Porto section, $452 \mathrm{~m}$ (A-3-44). Scale bars $=2 \mathrm{~mm}$

the marine part of the Alcobaça Formation are not purely siliciclastic but contain variable amounts of carbonate material, either components (ooids, bioclasts, intraclasts) or micrite. At the scale of the facies association, compositional mixing dominates (Chiarella et al. 2017), although stratal mixing is also widespread. Lithologies range from marly silt and mica-rich silt to fine-sandy siltstone, marly fine-grained sandstone and bioturbated fine-grained sandstone, the latter partly containing intraclasts or bioclasts (Fig. 19e). Plant fragments and lignite pieces are common; occasionally, convolute bedding is present, as is rare thinly interlayered bedding. Most of these sediments are bioturbated. Trace fossils include Thalassinoides, Rhizocorallium commune and Teichichnus.

Benthic organisms include lituolid foraminifera (e.g. Alveosepta jaccardi, Everticyclammina virguliana), burrowing bivalves (e.g. Mesosaccella, Corbulomima), oysters, occasional gastropods, brachiopods, echinoids (spines) and rare corals.

Interpretation: The various lithologies mentioned above represent low-energy environments of the shallow open shelf below the fair-weather wave-base, but within the reach of weak storms and/or episodic longshore currents that now and then introduced sediment by bed-load transport, which subsequently became bioturbated. Occasionally occurring interlayered bedding possibly points to a certain tidal influence or else records the influence of distal storm flows. Overall, the sedimentation rate was fairly low, so that siliciclastic material commonly became mixed with finegrained carbonate components.

High-energy siliciclastic to mixed carbonate-siliciclastic open shelf deposits (BA5)

Features: High-energy siliciclastic sediments are represented by fine- to coarse-grained arkosic to quartzose sandstones, which exhibit large-scale planar or trough cross-stratification and ripple cross-lamination. Sorting ranges from poor to well sorted. Occasionally, the sandstones are gravelly or conglomeratic and lenticular in nature. Pebbles are intraformational and consist of siltstone or sandstone (Fig. 19h), but gravel consists of well-rounded quartz grains. Lignite flakes and plant debris are common. Carbonate clasts (intraclasts, ooids, bioclasts, rarely oncoids or other coated grains) are commonly associated with the siliciclastic material, and the cement is sparite (Fig. 19d).

Although many of the sandstones are unfossiliferous, others contain fossils, which, in some cases, have been reworked from underlying strata or else are parautochthonous. The latter include nerineid gastropods, which may form layers, Isognomon, oysters, various species of bakevelliid and pteriid bivalves (Fig. 18a, b), red algae and also corals. Thin shell concentrations are occasionally present.

Interpretation: The large-scale sedimentary structures, including wave and current ripples, clearly indicate that the sandstones were deposited in open marine, shallow water above the fair-weather wave-base. Constant reworking prevented the sediment from becoming bioturbated. Such sandstones probably represent small sand waves, dunes and megaripple fields, which are moved across the shallow nearshore shelf by currents. Lenticular sandstone bodies are across and downslope channel fills, cutting down into underlying beds. Their faunal content is clearly allochthonous and commonly reflects several adjacent environments. This is supported by the carbonate components that are common constituents of the sandstones. The channels might represent subtidal tidal channels or channels connecting lagoons with the open sea. Channel sandstones with a basal lag of quartz gravel more likely are the submarine extension of distributory channels and reflect phases of elevated river discharge. Marine channel sandstones are particularly common in the upper, sand-prone part of the Consolação section (Fig. 11, from $108 \mathrm{~m}$ onwards) in a nearshore setting characterised by brackish-water biota. In that section, a several-metresthick fine-grained, well-sorted sandstone with horizontal to very low-angle cross-stratification, at $155 \mathrm{~m}$, has been interpreted as a beach deposit by Werner (1986).

Low-energy carbonate and mixed carbonate-siliciclastic shallow-water deposits (BA6)

This biofacies association includes deposits of the open shelf and of marine lagoons. Carbonate deposits dominate but are commonly blended with a subordinate siliciclastic component, in variable proportions and grain sizes (clay to fine sand).

Features: The carbonate beds are characterised by a micritic matrix and a fabric that ranges from mudstones (rare) to wackestones and floatstones (abundant) (Fig. 19b), pack- 

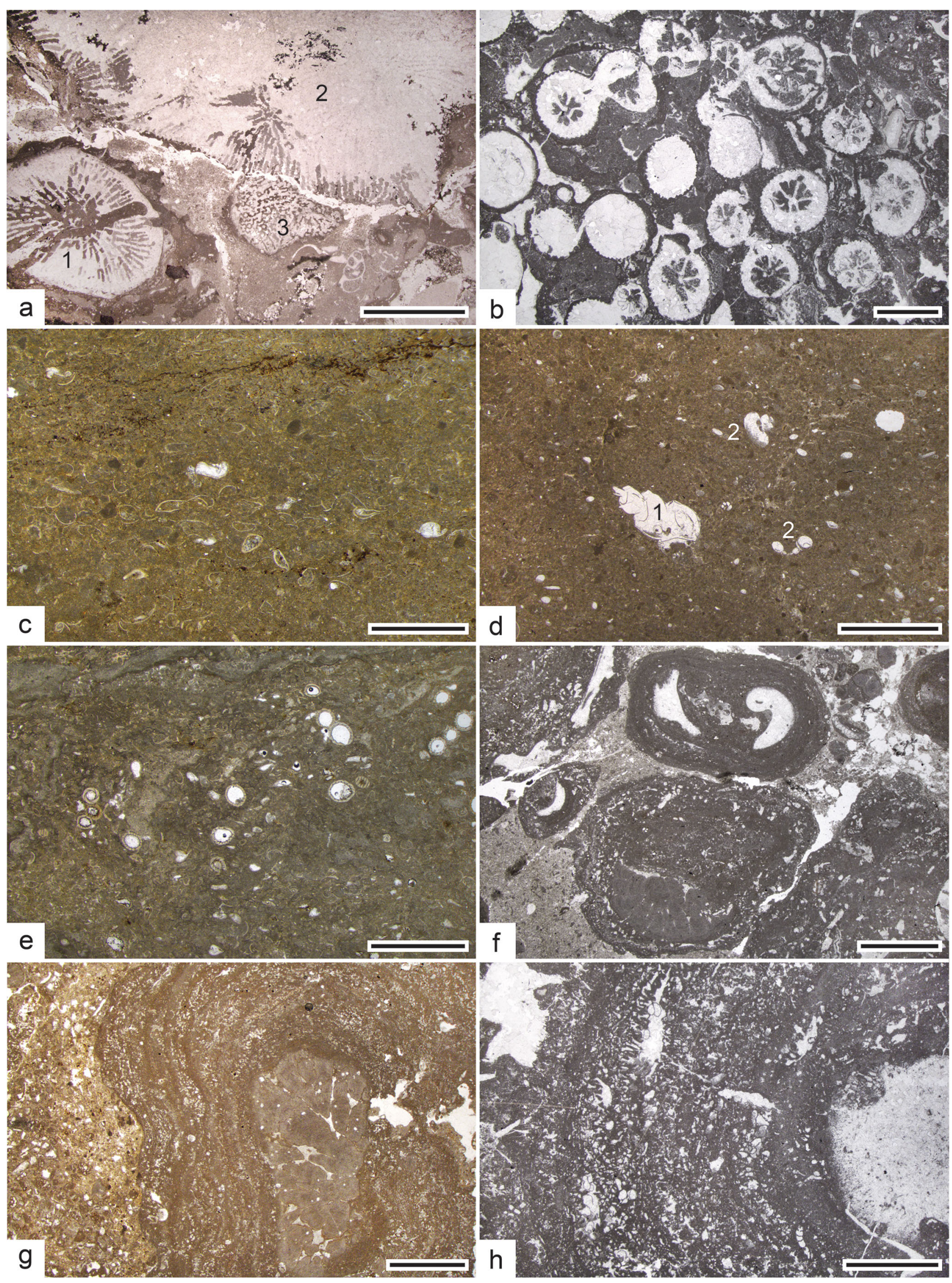
Fig. 20 Typical microfacies of the Alcobaça Formation. a Coral bindstone; (1) Thecosmilia sp. with microbial envelope; (2) ceriod coral; (3) calcareous sponge; Vestiaria Mbr; Vestiaria section, $104 \mathrm{~m}$ (A-15107). b Colony of the phaceloid coral Stylosmilia with dense microbial crusts and spar-filled cavities; Columbeira Mbr; Columbeira section, 285 m (A-28-97). c Ostracod packstone; São Martinho Mbr; São Martinho do Porto section, $61 \mathrm{~m}$ (A-1-11). d Mudstone with freshwater gastropods; (1) cf. Ptychostylus; (2) cf. Valvata; note the geopetal fabric within the gastropod shells and the meiofaunal bioturbation; Gralha Mbr; São Martinho do Porto section, 556 m (A-3-101). e Packstone with ostracods and gyrogonites; São Martinho Mbr; São Martinho do Porto section, $71 \mathrm{~m}$ (A-1-18). f Oncoid rudstone with single and composite Girvanella oncoids; cortex with Lithocodium; Columbeira Mbr; Columbeira section, 285 m (A-28-181). g Girvanella oncoid with cryptalgal fabric and red alga Marinella lugeoni Pfender as a nucleus; Gralha Mbr; São Martinho do Porto section, 563 m (A-3-112). h Oncoid cortex with Lithocodium aggregatum Elliott and Bacinella irregularis Radoičić; Columbeira Mbr; Columbeira section; 387 m (A-28-123). Scale bars: $\mathbf{a}=5 \mathrm{~mm} ; \mathbf{b}, \mathbf{d}-\mathbf{h}=2 \mathrm{~mm} ; \mathbf{c}=1 \mathrm{~mm}$

stones (common) (Fig. 20c, e) and rudstones (occurring) (Fig. 20f). Components include peloids (rare), intraclasts (abundant), bioclasts (abundant), oncoids (abundant) and other coated grains (common) (Table 1). Primary sedimentary structures are absent due to intense bioturbation. Recognisable trace fossils include Thalassinoides (two size classes), Rhizocorallium commune, Teichichnus, Planolites and Zoophycus. Algal lamination occurs at several levels in the São Martinho do Porto section (Fig. 9, at 13-16 m, 66$72 \mathrm{~m}$ ); coral meadows are common in the lower part of the Consolação section (Figs. 11 and $18 \mathrm{~g}$ ). Small coral patch reefs occur, e.g. in the Sobral da Lagoa section (Fig. 16, at 60$62 \mathrm{~m}$ ), commonly associated with microbial crusts (e.g. Figs. 12 and 20a, Vestiaria section at $104 \mathrm{~m}$ ). In the latter section (at 231-240 m), corals, sponges and microbialites form meadows and small patch reefs that can be traced laterally for several kilometres (Fürsich and Werner 1991). Birdseyes occur, for example, in mudstones (Amoreira section, Fig. 17 at $37 \mathrm{~m}$ ). Larger sparite-filled dissolution cavities occur at three levels in the Sobral de Lagoa section (Fig. 16, at $4 \mathrm{~m}, 12 \mathrm{~m}$ and $80 \mathrm{~m}$ ). Black pebbles are rare. Desiccation cracks occur, for example in the Salir do Porto section (Fig. 10, at $414 \mathrm{~m}$ ), associated with birdseyes and a rootlet horizon. Lignite pieces and plant fragments are rare.

The macrofauna is represented by a range of taxa, in particular bivalves (e.g. Actinostreon, Isognomon, Trichites, Arcomytilus, Corbulomima), gastropods (especially nerineids; Fig. 18d), serpulids, echinoids (spines), rare crinoids (ossicles), colonial and solitary corals, stromatoporoids and calcareous sponges. Occasionally, the molluscs form shell concentrations, but more commonly are scattered. The microfauna contains both ostracods and foraminifera (lituolids, miliolids), and the microflora includes Dasycladaceae. Red algae (Marinella) are common. In several horizons, the benthic macrofauna is the autochthonous relict of former communities (Fig. 21).

Interpretation: Some of the marine carbonate rocks are lagoonal in origin. This is supported, apart from their lowenergy features (i.e. the abundance of micrite and oncoids), by their close association with beds indicating brackish conditions. Apparently, during the time interval represented by the Alcobaça Formation, some areas were covered by a large lagoonal system, in which fully marine conditions (indicated by their faunal elements) alternated with brackish ones, depending on climatic conditions and on the degree, to which the lagoons were connected to the open sea.

The common clay- to sand-sized components in the carbonate beds point to nearby siliciclastic sources, most likely small deltas. This is also true of the carbonate deposits that accumulated on the shallow shelf, but generally in protected settings in embayments, or behind barriers, formed, e.g. by ooidal or intraclastic shoals (see below). In these settings, moderately diverse coral meadows flourished and small patch reefs became established. That the water depth was, at least locally, extremely shallow is shown by algal mats, birdseyes and signs of emersion such as desiccation cracks, all typical features of peritidal conditions (e.g. Flügel 2010: 746). Several horizons in the Sobral da Lagoa area exhibit small dissolution cavities, which are commonly linked to pebble lags. These features are interpreted to indicate more extensive periods of emergence and a certain degree of karstification and may signal abrupt local to regional adjustments in sea level.

High-energy, fully marine carbonate and mixed carbonatesiliciclastic shelf deposits (BA7)

Features: These carbonate deposits are mainly characterised by sparite cement and a well-washed fabric (grainstones and rudstones), occasionally also by packstones. Allochems are intraclasts, ooids, bioclasts, cortoids and oncoids (Figs. 18a, c and 19a, c, f). Some of the oncoids have a cortex of Lithocodium and Bacinella (Fig. 20h), others a nucleus of the red alga Marinella (Fig. 20g). Black pebbles occur occasionally, as do lignite pieces and plant debris, the latter concentrated on large foresets. The plant remains are more common in beds that also contain quartz grains. Primary sedimentary structures are widespread and include large-scale trough and planar cross-stratification. Densely to loosely packed shell concentrations occur repeatedly. Some of the carbonate beds contain a high percentage of quartz grains. In a single case (SOB section, Fig. 16 at $218 \mathrm{~m}$ ), glauconite grains are a common constituent of an ooidal grainstone. Rarely, layers with intraformational sandstone or siltstone pebbles occur. Sparite-filled dissolution cavities occur at the top of an oncoidal-ooidal grainstone in the Columbeira section (Fig. 14 at $433 \mathrm{~m}$ ). 

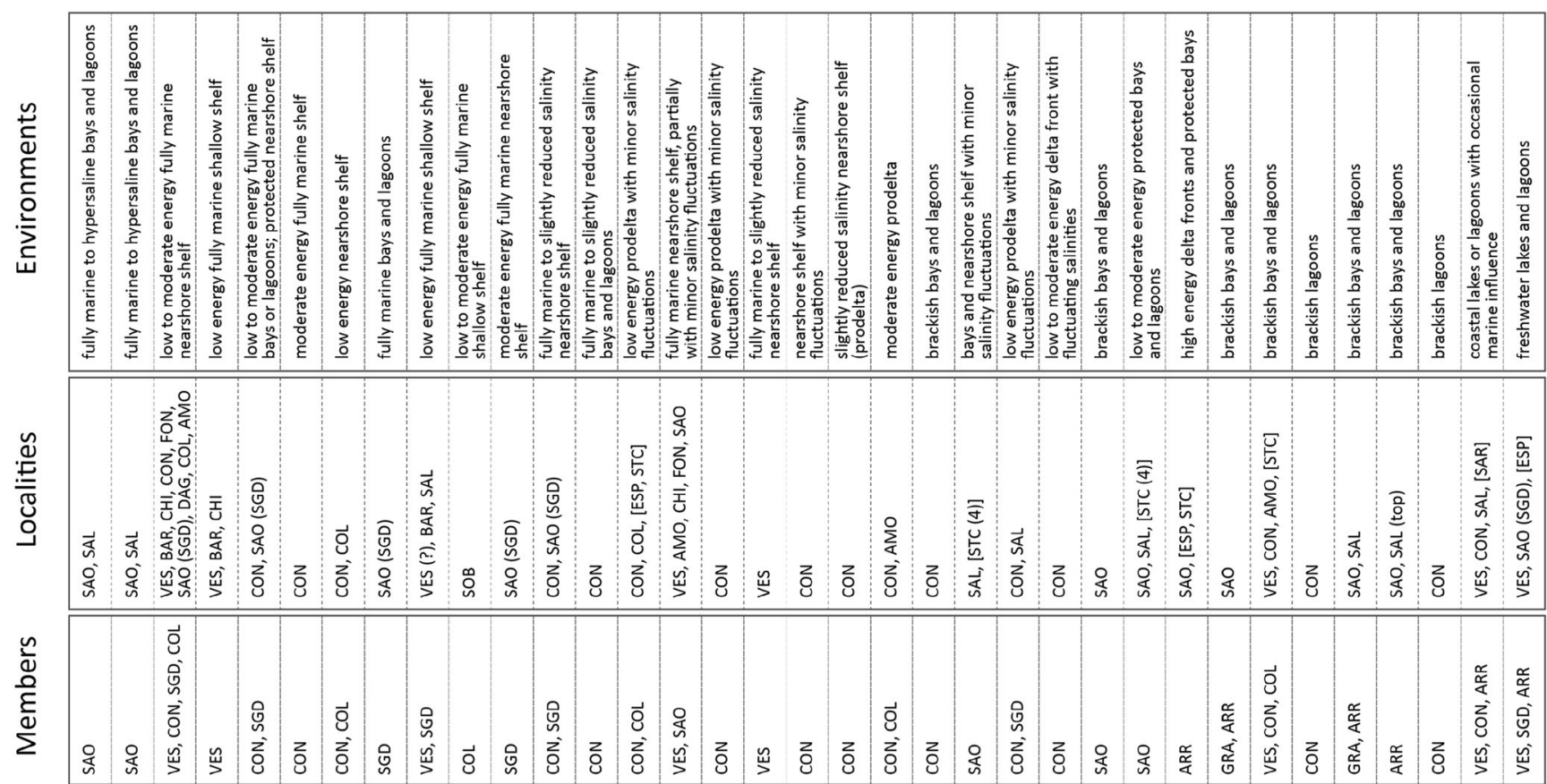
部:
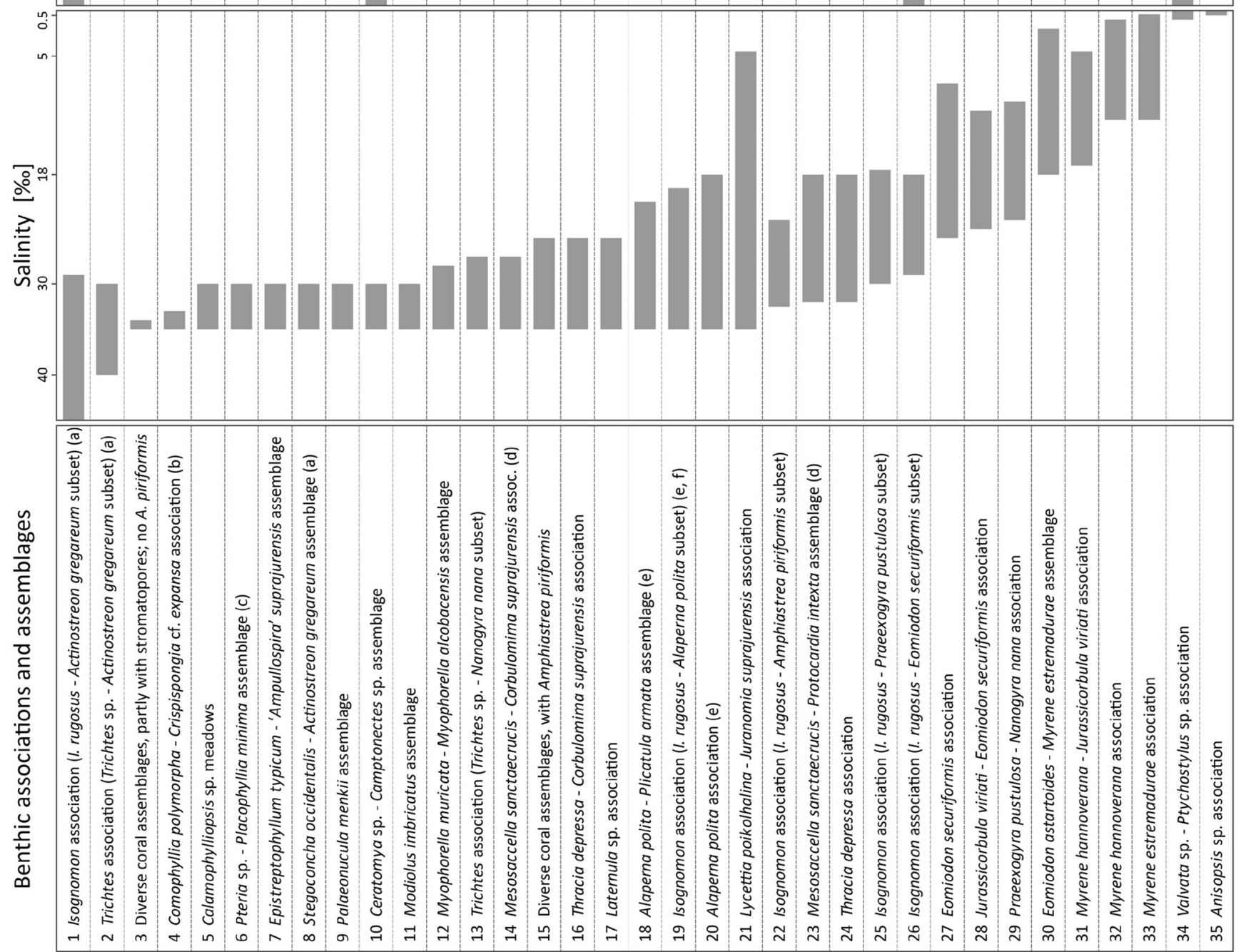
4Fig. 21 Benthic associations and assemblages of the Alcobaça Formation, their salinity range (in \%o), their facies range (c, carbonate, $\mathrm{s}$, siliciclastic, $\mathrm{m}$, mixed), their distribution within members of the Alcobaça Formation, their distribution in logged sections and additional outcrops of the Alcobaça Formation (and elsewhere in the Lusitanian Basin) and their environmental preference. The following letters refer to the terminology used by Fürsich and Werner (1986) (F \& W): (a) Actinostreon gregareum = Lopha solitaria of F \& W; (b) Elasmostoma sp.-Comophyllia corrugata ass. of F \& W; (c) Pteria sp. = Pteroperna $\mathrm{sp}$. of F \& W; (d) Mesosaccella sanctaecrucis $=$ M. dammariensis of $\mathrm{F} \& \mathrm{~W}$. (e) Alaperna polita $=$ Bakevelliid sp. A of F \& W. (f) Isognomon rugosus is succeeded by $I$. lusitanicus in younger strata. AMO Amoreira, ARR Arrinhada, BAR Barrio, $C H I$ Chiqueda, $C O L$ Columbeira, $C O N$ Consolação, DAG Dagorda, ESP Cabo Espichel, FON Fonte Santa, GRA Gralha, SAL Salir do Porto, SAO São Martinho do Porto, SAR Serra d'Arrábida, $S G D$ Salgado, $S O B$ Sobral da Lagoa, STC Santa Cruz, VES Vestiaria

Faunal components include corals, bivalves (in particular oysters; Fig. 18f), gastropods (mainly nerineids; Fig. 18d), brachiopods and stromatoporoids. In addition, red algae of the genus Marinella are common, while Cayeuxia cyanobacteria are rare. Dinosaur tracks cover a large bedding plane of a sandy bioclast rudstone south of Salgado (SAO section, Fig. 9 at $555 \mathrm{~m}$, Fig. 23a). Similar tracks are present near the base of the Sobral da Lagoa section (Fig. 16 at 4 m; Fig. 7d), where they occur on top of a pebbly bioclast grainstone.

Interpretation: The primary sedimentary structures, fauna and lack of micrite indicate that the sediments formed in highenergy shallow waters above the fair-weather wave-base. There they formed shoals and barriers, the tops of which were constantly reworked. Occasional dinosaur tracks point to extremely shallow water or temporary emergence, and dissolution cavities indicate a longer phase of subaerial exposure and karstification. In some sections (e.g. SOB, DAG, COL), oncoids are common in intraclastic and ooidal grainstones and occasionally form rudstones (Fig. 18c). As oncoids grow under low-energy conditions, only intermittently disturbed by high-energy events (e.g. Flügel 2010: 136), their inclusion in grainstones and rudstones indicates that, apart from the ooids, many of the components of these carbonate beds are allochthonous and were transported from their respective place of origin. This is also true of many of the fossil components, especially those of shell concentrations, which did not live in these turbulent environments. Transport and mixing is also indicated by the siliciclastic components.

Brackish-water deposits of lagoons and protected bays (BA8)

Features: This type of biofacies comprises a wide range of lithologies characterised by microfauna and/or macrofauna, which lived in salinity regimes deviating from fully marine (euhaline) conditions. Various lithologies are included. Low-energy carbonate facies comprise micritic algal laminites, marl and marly wackestone. Mixed carbonate-siliciclastic rocks are represented by silty mudstone with birdseyes, rootlets and the trace fossils Psilonichnus and by silty marl with typical brackishwater bivalves (Isognomon, Eomiodon, Neomiodon, Jurassicorbula, Praeexogyra), ostracods and, more rarely, lituolids. Low-energy siliciclastic rocks include silt, finesandy silt, argillaceous silt and fine-grained sandstone, with a similar benthic fauna. High-energy siliciclastic beds (medium- to coarse-grained sandstones, occasionally pebbly and large-scale trough or planar cross-bedded) with the trace fossils Polycladichnus and Diplocraterion are comparatively rare. Finely to coarsely interlayered bedding is usually associated with abundant plant debris. In rare cases, desiccation cracks occur.

Lignite flakes are generally abundant, and rootlets are occasionally present; fragments of vertebrates (teeth, bones) are rare. Freshwater gastropods, such as Amplovalvata, and unionid bivalves are occasionally associated with the typical brackish-water faunal elements. Small patch reefs composed of the oyster Praeexogyra occur in the Consolação section (Fig. 11 at 134 m; Fig. 18e).

Interpretation: The predominantly subaqueous lithologies and their benthic microfauna and macrofauna characterise mainly very shallow, low-energy coastal environments such as protected embayments and lagoons, more rarely high-energy environments such as tidal and lagoonal inlets. In these environments, salinities not only were generally lower than in the open sea but also commonly fluctuated. This is indicated in some cases by the presence of freshwater elements, which might have been introduced by rivers, but also could have populated the same area during times when lagoons were temporarily completely cut off from the open sea. The opposite case is demonstrated by fully marine faunal elements in brackish biota, which document occasional influx of fully marine waters. In several horizons (e.g. SAO section between 44 and $53 \mathrm{~m}$; Fig. 9), the benthic macrofauna, dominated by Isognomon rugosus, Trichites and Actinostreon gregareum, suggests slightly elevated rather than lowered salinity values, i.e. in the lower hypersaline regime (Fürsich and Werner 1986). The various salinity regimes indicated by the benthic fauna are discussed below in more detail.

\section{Benthic macrofauna}

While nektobenthic ammonites and nektonic belemnites are extremely scarce in the Alcobaça Formation, benthic macroinvertebrates are very common. They are either recurring autochthonous to parautochthonous relicts of former communities (associations) or are allochthonous elements that 


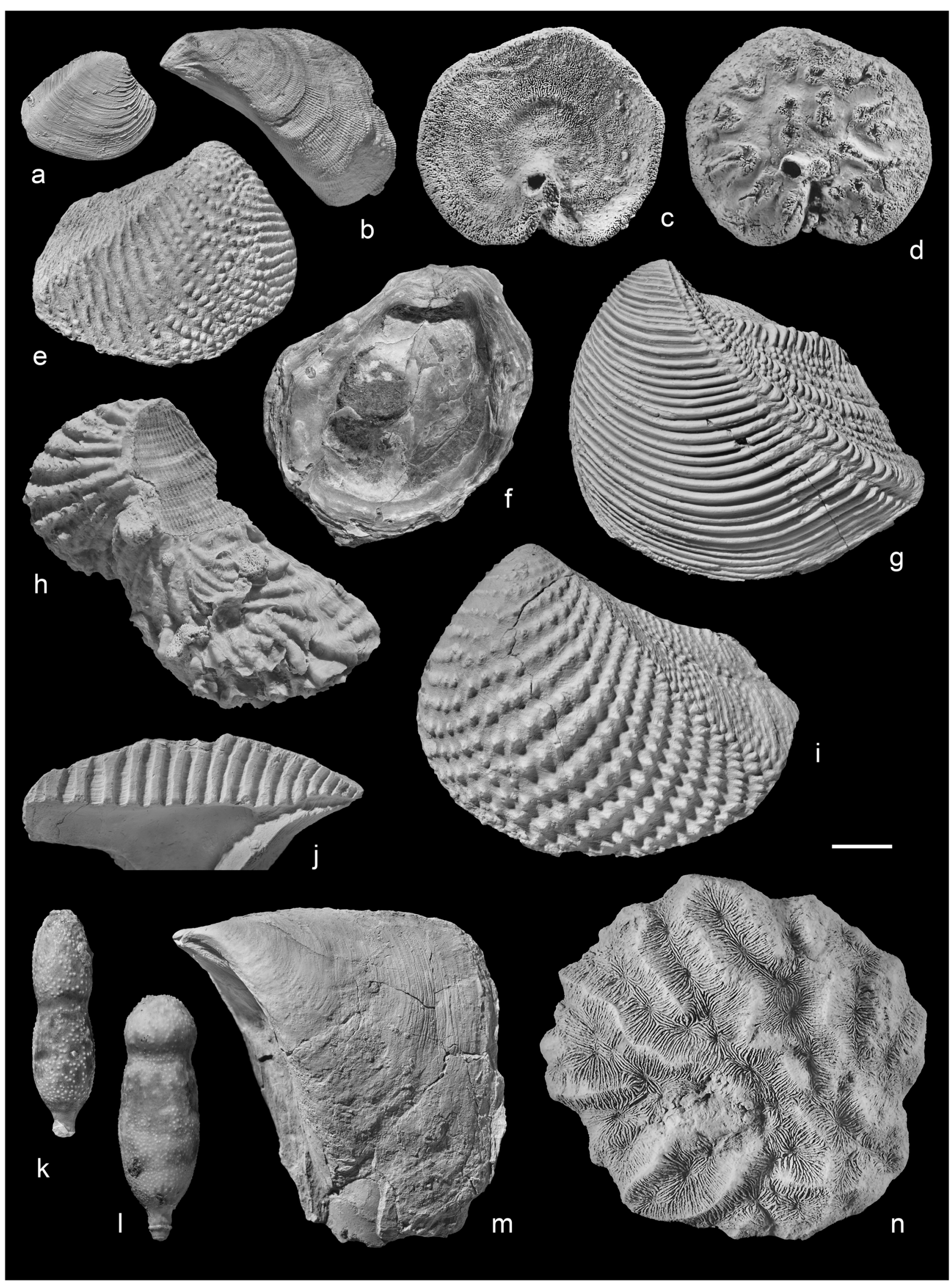


4 Fig. 22 Typical macrofauna of the Alcobaça Formation. a Eomiodon securiformis (Sharpe); Vestiaria Mbr, Vestiaria; GML 25919. b Arcomytilus morrisii (Sharpe); Consolação Mbr, Consolação section; GML 25901. c, d Crispispongia cf. expansa (Quenstedt); Vestiaria Mbr, Vestiaria; SNSB-BSPG 1984 XXII 20. e Myophorella alcobacensis (Choffat); Vestiaria Mbr; Chiqueda; GML 31985. f Praeexogyra pustulosa (Sharpe); Columbeira Mbr; Sobral da Lagoa; SNSB-BSPG 2005 V 29. g Trigonia pseudomeriani Choffat; 'Environs de Alcobaça'; GML 2027. h Actinostreon gregareum; Salgado Mbr; Salgado; SNSBBSPG 2005 V 28. i Myophorella muricata (Goldfuss); 'Environs de Alcobaça'; GML 1997. j, m Isognomon rugosus (Münster); Vestiaria Mbr; Fonte Santa; J: GML 25923; M: GML 25906. k, I Club-shaped spines of Pseudocidaris lusitanica de Loriol; note the remnants of colour pattern. k Vestiaria Mbr; Vestiaria; GML 4115. I Columbeira Mbr; Sobral da Lagoa; SNSB-BSPG 1984 XXII 353. n Comophyllia polymorpha Koby; Vestiaria Mbr; Barrio; SNSB-BSPG 1984 XXII 32. Scale bar = $10 \mathrm{~mm}$

underwent transport and often occur concentrated in shell beds and shell lenses (transported assemblages). Autochthonous to parautochthonous faunas, if occurring only once but not repeatedly, are also termed assemblages. Bivalves are the most abundant macrofossils, followed by corals, gastropods, brachiopods, echinoids (mainly represented by spines), stromatoporoids and serpulids. Bryozoans, crustacean fragments, asteroid ossicles and crinoid skeletal elements are comparatively rare. Some characteristic elements of this fauna are shown in Fig. 22.

A number of papers have been published on the Late Jurassic benthic macrofauna of the Lusitanian Basin during the last few decades (e.g. Fürsich 1981b; Fürsich and Werner 1984, 1985, 1986, 1988, 1989a, b, 1991; Werner 1986; Leinfelder et al. 1996; Nose and Leinfelder 1997; Leinfelder 2001; Fürsich et al. 2009; Schneider et al. 2010a, b, 2011). They concentrated on the taxonomy of bivalves and on the palaeosynecology of the macrobenthos, but a substantial part of that information had been gained from other parts of the Lusitanian Basin. Here, we provide a brief overview on the 35 benthic associations/assemblages identified in the Alcobaça Formation, many of which apparently lived in salinity regimes deviating from normal marine values. Most of the associations/assemblages listed in Fig. 21 were already briefly discussed by Fürsich and Werner (1986), but the present list contains additional data from both fully marine and brackish environments of the Alcobaça Formation. The salinity ranges of associations have been determined based on ecological indicators (species richness and evenness), taxonomy and comparison with modern relatives, species composition, the associated microfauna and microflora, morphological features such as shell thickness and shell size, as well as lithofacies and sedimentary structures. The results were corroborated to some extent by stable isotope data (Fürsich and Werner 1986; Yin et al. 1995). It should be kept in mind that the ranges given in Fig. 21 are approximations. Moreover, in cases where taxa that are characteristic of different salinity regimes co-occur in the same layers, we are most likely dealing with fluctuations in salinity and not simply with reduced, but stable values. After all, this is what one would expect in marginal marine environments, in particular lagoons. Also, along the salinity range of a particular association, the faunal composition and diversity usually changes, and these features have been used to define the range. The associations are discussed in numerical order and by decreasing salinity regime below.

Only two of the 35 associations in Fig. 21, i.e. the Isognomon rugosus-Actinostreon gregareum (1) and the Trichites sp.-Actinostreon gregareum subset (2), tolerated slightly hypersaline waters. This interpretation is supported by small authigenic euhedral quartz crystals occurring in the carbonate to mixed carbonate-siliciclastic rocks, which indicate saline pore waters (e.g. Friedman 1980; Chafetz and Zhang 1998), potentially derived from the underlying diapir. These associations are restricted to the São Martinho Member at São Martinho do Porto and Salir do Porto. Alongside abundant red-bed facies, they suggest a semi-arid climate with little freshwater influx.

Several associations appear to have been restricted to fully marine (euhaline) environments. They include diverse coral meadows, partly associated with stromatoporoids (3); meadows in which the coral Calamophylliopsis dominated (5); or assemblages, in which corals were accompanied by a diverse bivalve and gastropod fauna (Pteria-Placophyllia and Epistreptophyllum typicum-'Ampullospira' suprajurensis assemblages; 6, 7). Such coral meadows and other associations dominated by corals occasionally forming small patch reefs are particularly common in the lower part of the Consolação Member, but occur also in the other dominantly marine members (e.g. patch reefs or meadows dominated by the phaceloid coral Calamophylliopsis). A particularly diverse association is the Comophyllia polymorpha-Crispispongia cf. expansa association (4), which is represented by 131 taxa, of which half are corals and approximately $20 \%$ are small calcareous sponges (Fürsich and Werner 1991). Associated with them are bivalves, brachiopods, crinoids and gastropods and a rich encrusting and boring biota. In the Vestiaria Member, this association formed meadows and small patches on a mixed carbonate-siliciclastic sea floor. The respective horizon can be traced for more than $10 \mathrm{~km}$ west to east in the northern part of the study area, from Barrio via Vestiaria to Chiqueda (Fig. 3). Apart from this occurrence, calcareous sponges are rare in the benthic community relicts of the Alcobaça Formation. Several other marine assemblages are dominated by bivalves. These include the large semi-infaunal Stegoconcha, which provided the substrate for the encrusting oyster Actinostreon gregareum (8) or Modiolus imbricatus (11), both from the Salgado Member. Assemblages characterised by the deposit-feeding Palaeonucula menkii (9) occur in the Salgado and Vestiaria 
members. The deep infaunal Ceratomya and epibyssate Camptonectes (10) typify an association restricted to the Columbeira Member at Sobral da Lagoa.

Another group of essentially marine associations/ assemblages (12-17) appears to have been tolerant of slightly reduced/fluctuating salinity values and is mainly known from the Consolação and Vestiaria members. Assemblage (15) is dominated by corals, including Amphiastrea piriformis, and occurs in most sections of the São Martinho and Vestiaria members. The remaining associations are characterised by bivalves. Two species of the shallow infaunal Myophorella are the main components of assemblage (12). Association (13) is characterised by the semi-infaunal Trichites forming secondary hard substrates for the small oyster Nanogyra nana. Three associations are dominated by infaunal taxa: the shallow infaunal deposit-feeding Mesosaccella and the suspension-feeding infaunal Corbulomima (14), the suspension-feeding infaunal Thracia and Corbulomina (16) or the deeply burrowing Laternula (17). All six groupings occur in fine-grained siliciclastic or mixed substrates and occupied marine lagoons or protected bays.

Three other bivalve-dominated groupings (18-20) apparently occupied not only euhaline but also brachyhaline settings. They lived in partly marly bioclastic fine sand and are characterised by the epibyssate bakevelliid Alaperna (20), which co-occurs in some beds with either the cementing Plicatula (18) or the endobyssate Isognomon (19). The Lycettia-Juranomia association (21) had the widest salinity tolerance of all Alcobaça Formation associations, ranging from the euhaline to the upper oligohaline regime. Along this range, the composition of the accompanying taxa, mainly shallow burrowing bivalves, and the species diversity change accordingly. Associations (22) to (26) have a greater tendency to the brachyhaline regime, and some $(25,26)$ are restricted to it. Again, they are dominated by bivalves. Three of them are dominated by Isognomon, which serves as a substrate for either the eurytopic coral Amphiastrea piriformis (22) or the oyster Praeexogyra pustulosa (25) or else co-occurs with the shallow burrowing suspension-feeding bivalve Eomiodon (26). The infaunal Mesosaccella-Protocardia assemblage (23) and the Thracia depressa association (24) occur in finegrained siliciclastic deposits of the low-energy nearshore shelf.

The bivalve-dominated associations (27-29) signify the brachyhaline to mesohaline regime. The low-diversity Eomiodon securiformis association (27) occurs in delta-front sandstone elsewhere in the Lusitanian Basin (e.g. at Santa Cruz; Fürsich 1981b), but in the Alcobaça Formation occupied protected bays and lagoons of the Arrinhada Member (São Martinho do Porto section). Together with a small corbulid, Eomiodon forms the infaunal Jurassicorbula viriatiEomiodon securiformis association, typical of low-energy bays and lagoons. The brackish-water oyster Praeexogyra pustulosa formed small patch reefs together with the small eurytopic oyster Nanogyra nana (28), again in lagoonal settings and protected embayments. Small-sized coral colonies occurring at some levels within the patch reefs point to strong salinity fluctuations. Similarly, Nanogyra might have replaced Praeexogyra as a reef constructor during times when salinity was at the upper brachyhaline end.

The mesohaline to oligohaline regime is represented by four associations (30-33), which are dominated by small, shallow-infaunal suspension-feeding bivalves and occur in fine-grained siliciclastic sediments (e.g. argillaceous silt), deposited in lagoons and protected bays. They all exhibit very low species diversities. The dominant species Eomiodon astartoides (30), Myrene estremadurae (30, 33), Myrene hannoverana (32) and Jurassicorbula viriati (31) belong to genera that have been well established as brackish endemic taxa elsewhere in the Jurassic (e.g. Hudson 1963a, b; Huckriede 1967; Mongin 1967; Fürsich 1994).

The freshwater regime is represented by two associations that consist of small gastropods: the Valvata-Ptychostylus association (34) and the Anisopsis association (35). They generally occur in fine-grained siliciclastic deposits but also in mixed sediments and in carbonate mudstones characterising freshwater lagoons and lakes of the coastal plain (CON, VES and ARR members). They have also been recorded from the Serra d'Arrábida and Cabo Espichel south of Lisbon. Unionid bivalves have not been found during our investigations but have been recorded by Choffat (1885-1888).

Additional associations and assemblages in the Alcobaça Formation certainly exist, but we lack statistical data on their composition. Worth mentioning are nerineid assemblages that occur in both high-energy carbonate and siliciclastic rocks (Fig. 18d). They represent transported and probably sorted relicts of one or several former gastropod-dominated communities. Some of the associations and assemblages listed above occur only in a single section. This may partly be an artefact, as statistically significant samples could not be obtained everywhere, but surely also reflects the great environmental heterogeneity represented by the Alcobaça Formation.

Palaeoecological analysis of benthic macrofauna, supported by an array of other palaeontological and sedimentological data, is a powerful tool to reconstruct palaeoenvironments. This is particularly well illustrated by the Alcobaça Formation, which records high-frequency changes between shallow-marine, nearshore and non-marine conditions in both time and space, and is here interpreted to document the salt tectonic evolution of the Lusitanian Basin during the Kimmeridgian time interval.

\section{Microfossils}

Foraminifera and ostracods are ubiquitous constituents of the Alcobaça Formation, occurring with assemblages of varying 
compositions in different biofacies. Despite their widespread occurrence, taxonomic studies of these groups are rather scant. Foraminifera have been mentioned in several articles (e.g. Fatela 1990; Werner 1986; Fürsich and Werner 1991), but a detailed taxonomic treatment of this group from the Alcobaça Formation is still lacking. In contrast, the ostracods of the Alcobaça Formation have been the subject of several studies, largely focussing on the biostratigraphy of the mammalianbearing Guimarota beds (e.g. Helmdach 1968, 1971a, b, 1974; Schudack 2000a, b). A more comprehensive study of the ostracods of this formation by the late F.-F. Helmdach remains unfinished (see above). Some legacy data from this study are incorporated here.

Among the foraminifera, lituolid taxa dominate in nearly all marine biofacies, where they are frequently abundant. They are represented by species that are globally characteristic of the Kimmeridgian at low to moderately high latitudes, but are generally not diagnostic at substage scale (e.g. Alveosepta jaccardi, Everticyclammina virguliana, Rectocyclammina chouberti, Pseudocyclammina parvula). Further common agglutinated foraminifera are Ammobaculites and Nautiloculina. As demonstrated in the Consolação section, lituolids decrease in diversity and abundance towards facies with strongly reduced salinity, where they are almost exclusively represented by Pseudocyclammina parvula (Werner 1986). Miliolids are also common constituents and generally occur in low-energy environments with reduced influx of siliciclastic material (e.g. wackestones), where they are often accompanied by Dasycladales (e.g. Acicularia). Apart from the free-living benthic foraminifera, fixo-sessile cementing foraminifera (e.g. Placopsilina, Bullopora, nubeculariids, Tolypammina) are common epibionts in euhaline to brachyhaline habitats, settling on various available surfaces, including corals, coralline sponges, molluscs or microbial crusts. Some of these taxa, e.g. Placopsilina, Bullopora and the questionable rotaliid foraminifer Koskinobullina socialis (e.g. Sánchez-Beristain and Reitner 2019), are also common epibionts on accretion layers of Girvanella oncoids in lagoonal settings.

Ostracods occur in a wide range of aquatic biofacies of the Alcobaça Formation. Apart from their stratigraphic value (see above), they are very useful as salinity indicators. The most common taxa of euhaline to brachyhaline bays and lagoons are Schuleridea (several different species, e.g. Fig. 6n), Cytherella suprajurassica (Fig. 6o) and Cytherelloidea aff. weberi (Fig. 6g). Additionally, Fürsich and Werner (1991) reported species of Lophocythere, Terquemula and Protocythere from the fully marine, widely distributed coralline sponge-coral meadows in the surroundings of Alcobaça. Several genera, such as Theriosynoecum (Fig. 6a, c, e), Bisulcocypris (Fig. 6k, l) and Timiriasevia (Fig. 6b), are considered indicative of freshwater environments. However, it should be noted that some of these taxa may also have coped with brackish conditions (Schudack 2000b). This is also true of the species Cetacella inermis (Fig. 6m), Cetacella striata (Fig. 6f), Poisia bicostata (Fig. 6h), Poisia clivosa (Fig. 6q) and Dicrorygma (Orthorygma) aff. reticulata (Fig. 6r), all of which occurred in brackish bays and lagoons within the Alcobaça Formation (e.g. in the Vestiaria and Consolação sections).

\section{Ichnofauna}

Bioturbation is ubiquitous in low-energy carbonate and siliciclastic facies within the Alcobaça Formation, because sufficient time was available for organisms to rework the substrate. The same is true of discrete trace fossils, whereby a few ichnogenera strongly dominate. Trace fossils from the Alcobaça Formation have been described and/or figured by Fürsich (1981a), Neto de Carvalho and Baucon (2010), Neto de Carvalho et al. (2010) and Neto de Carvalho (2016). In terrestrial red beds, particularly in fine-grained wet floodplain sediments, Scoyenia, a more or less horizontal burrow with scratch marks and a meniscate backfill, is very abundant (Fig. 23g). Psilonichnus tubiformis, several-cm-thick, mainly vertical shafts with short horizontal to oblique side branches, most likely produced by crabs, occur in lowenergy coastal environments and may extend downwards for at least $2 \mathrm{~m}$. They commonly start with a Y- or Ushaped tube (Fig. 23b) and may cross through layers representing alternations of non-marine and marginal marine (possibly tidal) conditions. From a similar environmental setting at Salgado, Neto de Carvalho et al. (2010) and Neto de Carvalho (2016) also recorded the banana-shaped crab burrow Macanopsis plataniformis, a curved lined burrow that starts as a subvertical shaft and turns horizontal, as well as other types of crab burrows (Fig. 23h). In deltaic coarsegrained to microconglomeratic sandstones of the Consolação section, Polycladichnus irregularis is common. This trace fossil is characterised by strongly lined shafts with Y-shaped bifurcations connecting to the bedding surface, and its maker may have been able to withstand salinity fluctuations. The vertical U-shaped spreiten burrow Diplocraterion parallelum is common in mediumto coarse-grained brackish-water tidal creek sandstones of the Consolação section. In low-energy carbonate and siliciclastic sediments of the shallow shelf, crustacean burrows, in particular the horizontal U-shaped spreiten burrow Rhizocorallium commune (Fig. 23d) and the network-forming Thalassinoides suevicus with Y-shaped branching burrows, are very common. The latter occurs in several size classes with the largest burrows reaching 4$5 \mathrm{~cm}$ in diameter (Fig. 23c). The former occurs associated with Thalassinoides or on its own. The fairly non-descript Planolites isp., a simple, unlined horizontal burrow, is widespread and occurs in a number of facies. A much rarer 

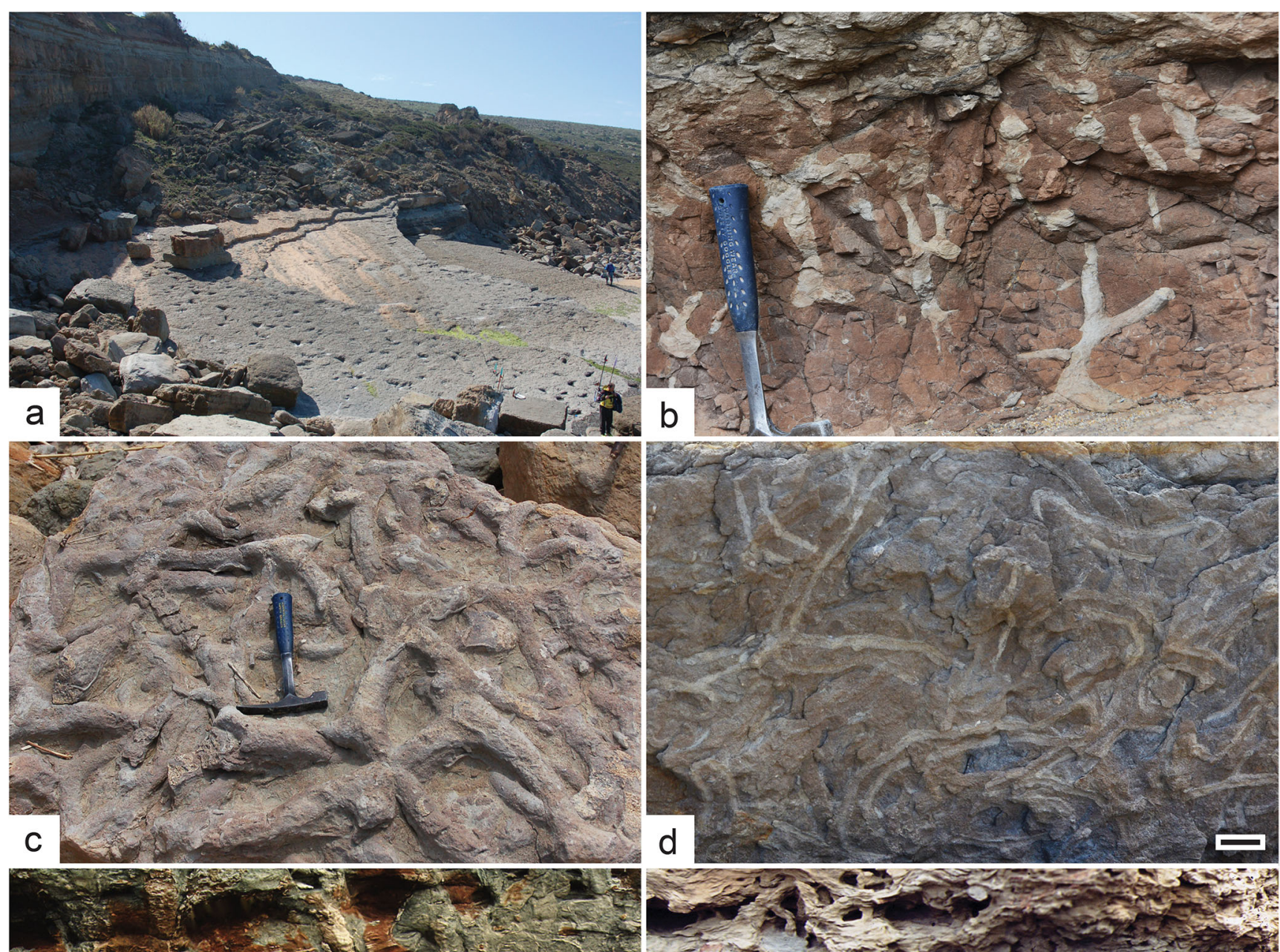

d

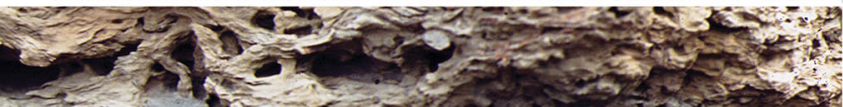

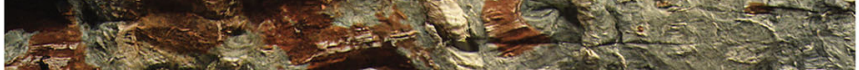

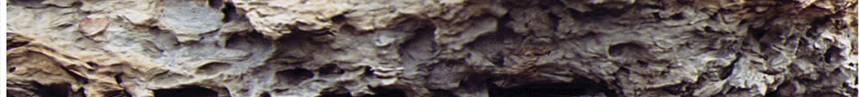

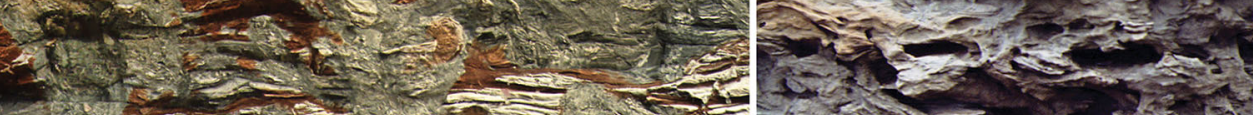
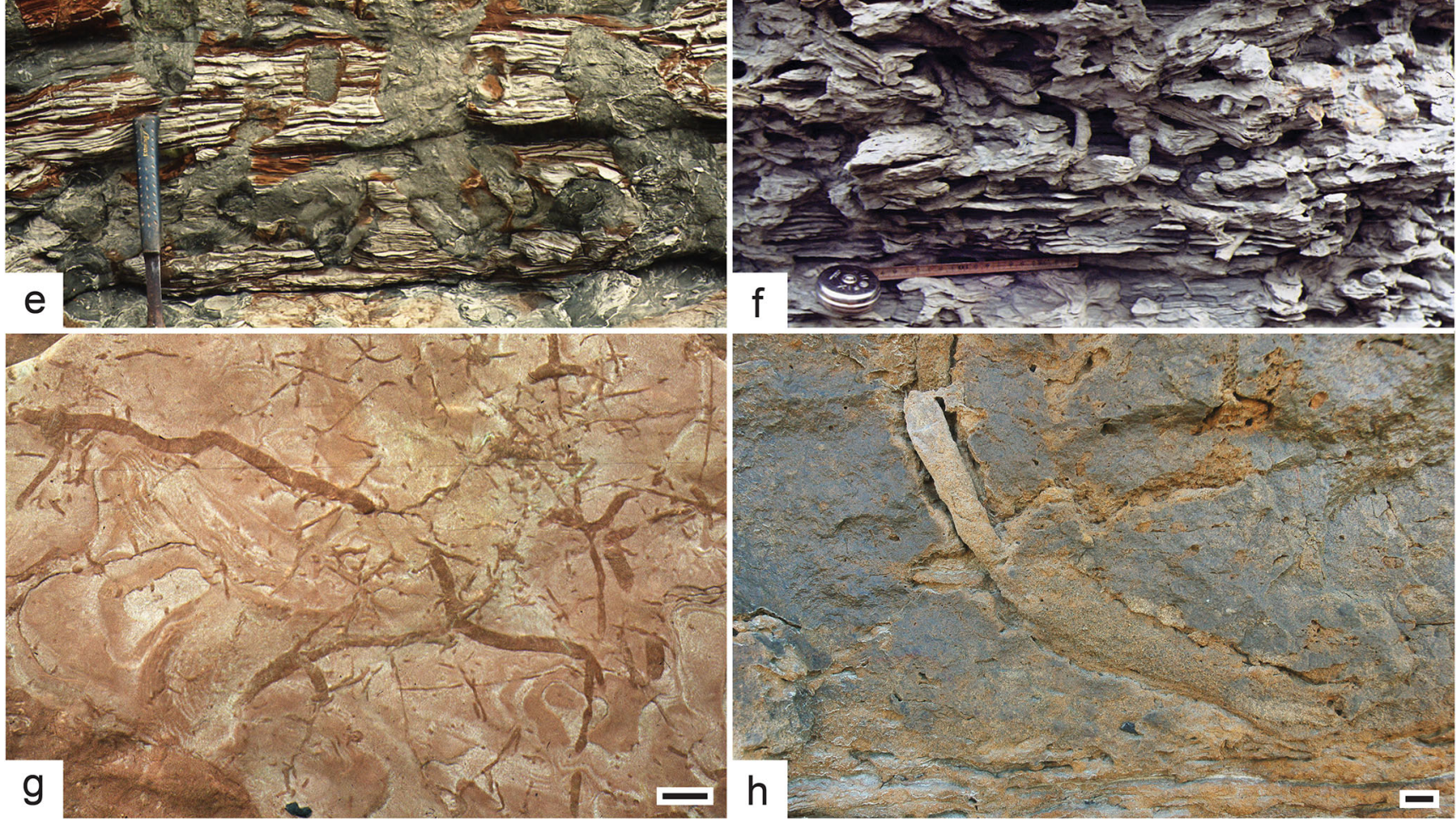

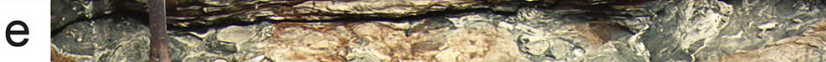


4 Fig. 23 Typical ichnofossils of the Alcobaça Formation. a Dinosaur tracks; Salgado Mbr; São Martinho do Porto section, 565 m. b Psilonichnus tubiformis Fürsich; Salgado Mbr; São Martinho do Porto section, $569 \mathrm{~m}$; type locality and horizon of the ichnogenus and ichnospecies. c Thalassinoides suevicus (Rieth); Salgado Mbr; São Martinho do Porto section, fallen block, $\sim 595 \mathrm{~m}$. d Rhizocorallium commune Schmid; Salgado Mbr; São Martinho do Porto section, fallen block, 593 m. e Psilonichnus sp.; Gralha Mbr; São Martinho do Porto section, 509 m. f Teichichnus rectus Seilacher; Consolação Mbr; Consolação section, 23 m. g Scoyenia sp.; Gralha Mbr; São Martinho do Porto section, 415 m. h Crab burrow; Salgado Mbr; São Martinho do Porto section, $578 \mathrm{~m}$. Scale bars: $\mathbf{d}=50 \mathrm{~mm} ; \mathbf{g}, \mathbf{h}=10 \mathrm{~mm}$

ichnospecies is Teichichnus rectus, an oblique cylindrical burrow with retrusive spreiten (Fig. 23f). Dinosaur tracks have been noted on several bedding planes in nearshore carbonate and mixed carbonate-siliciclastic strata (São Martinho do Porto section at Salgado, Fig. 23a; Salir do Porto, Sobral da Lagoa section, Fig. 7d). The trackways of Salgado have been identified as Brontopodus isp. and Megalosauripus isp. by Neto de Carvalho (2016) and are evidence of temporary (near-) emergence.

The ichnofauna can be accommodated in the classical ichnofacies scheme (e.g. Seilacher 1967; with subsequent additions, e.g. Bromley 1996), covering the non-marine Scoyenia ichnofacies, the high-energy marginal marine Skolithos ichnofacies, the low-energy marginal marine Psilonichnus ichnofacies and the Cruziana ichnofacies of the shallow shelf. In general, the distribution of the ichnotaxa corresponds well with the environmental interpretation deduced from grain size, microfacies and sedimentary structures.

\section{Discussion}

Facies pattern and correlation

Comparing and correlating the various sections of the Alcobaça Formation is difficult, because in many of them, neither the base nor the top of the formation is seen, and none of the sections captures both. At outcrop, underlying strata commonly comprise dolostones or marls of the Upper Triassic to Hettangian Dagorda Formation, but this contact is invariably tectonic in nature, although most probably not involving major displacement. The undisturbed base of the Alcobaça Formation is only exposed in the Fonte Santa section, where the unit overlies clean, thick-bedded limestones of the middle Oxfordian Montejunto Formation. The contact is sharp, probably representing a paraconformity. The upper boundary has been defined as the onset of thick fluvial sandstones, which are assigned to the Lourinhã Formation. This boundary, seen for example at the top of the Vestiaria section, is likely highly diachronous. Moreover, there are distinct lateral facies changes within the Alcobaça Formation between sections (Fig. 24). Although the four sections at Columbeira and Dagorda in the Bombarral Sub-basin, and at Amoreira and Sobral da Lagoa in the Consolação Sub-basin superficially look similar, the successions of marine siliciclastic and carbonate strata, and occasional brackish beds do not follow a clear vertical pattern and cannot be used for correlation (Fig. 24). Furthermore, all inland sections contain thick intervals of non-exposure, the nature (siliciclastic, mixed carbonate-siliciclastic) and environments of which (whether lake, lagoon, marine) cannot be reliably established. This makes lithostratigraphic correlation very difficult (see below). Unfortunately, due to the extreme scarcity of index fossils such as ammonites, it is impossible to place the tentative lithostratigraphic correlation shown in Fig. 24 on a sounder footing. Still, a distinct SE-NW zonation of the biofacies types introduced above becomes apparent, when comparing the different sections of the study area. The western sections, all situated in the Consolação Sub-basin (São Martinho do Porto, Salir do Porto and Consolação), are dominated by siliciclastic sediments. The comparatively short Consolação section shows a strong marine influence, especially in its lower part, while its upper third is characterised by brackish-water siliciclastic deposits. These are overlain conformably by thick grey to beige non-marine sandstones of the Lourinhã Formation. The brackish-water siliciclastic sediments at Consolação differ distinctly from the red beds of the Gralha Member at São Martinho and Salir do Porto, both with regard to colour and the thickness and abundance of sandstones. This suggests that the Gralha Member may have been deposited in a semi-arid climate, while the brackish succession at Consolação formed under a humid climate regime. For this reason, the Consolação Member is unlikely the equivalent of the Gralha Member but presumably corresponds to the Salgado and Arrinhada members of the upper São Martinho and Salir do Porto sections.

Further to the east, at Amoreira, Columbeira, Dagorda and Sobral da Lagoa, non-marine and brackish environments are absent and the successions are dominated by carbonate strata (Fig. 24). The Vestiaria and Fonte Santa sections occupy an intermediate position with minor red bed and lacustrine intercalations, common brackish-water intervals and a mixture of carbonate and siliciclastic sediments. The pattern of facies differentiation across the study area points to the presence of a topographic barrier and thus to distinct synsedimentary tectonic activity.

Control of diapirism on facies pattern and benthic communities

The most characteristic features of the Alcobaça Formation are the rapid vertical and lateral changes in facies and benthic 

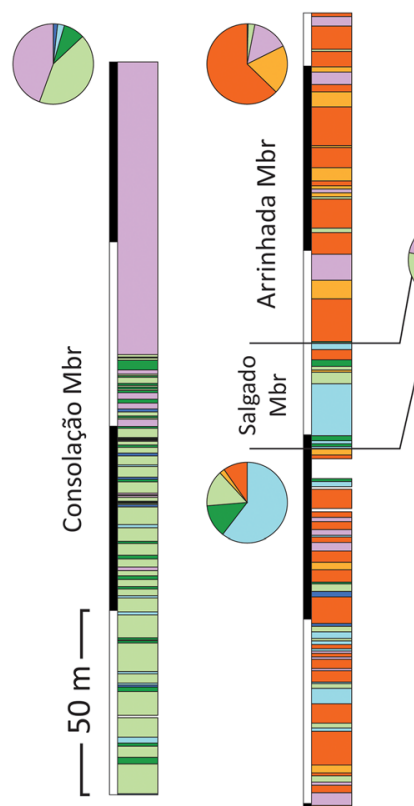

CON
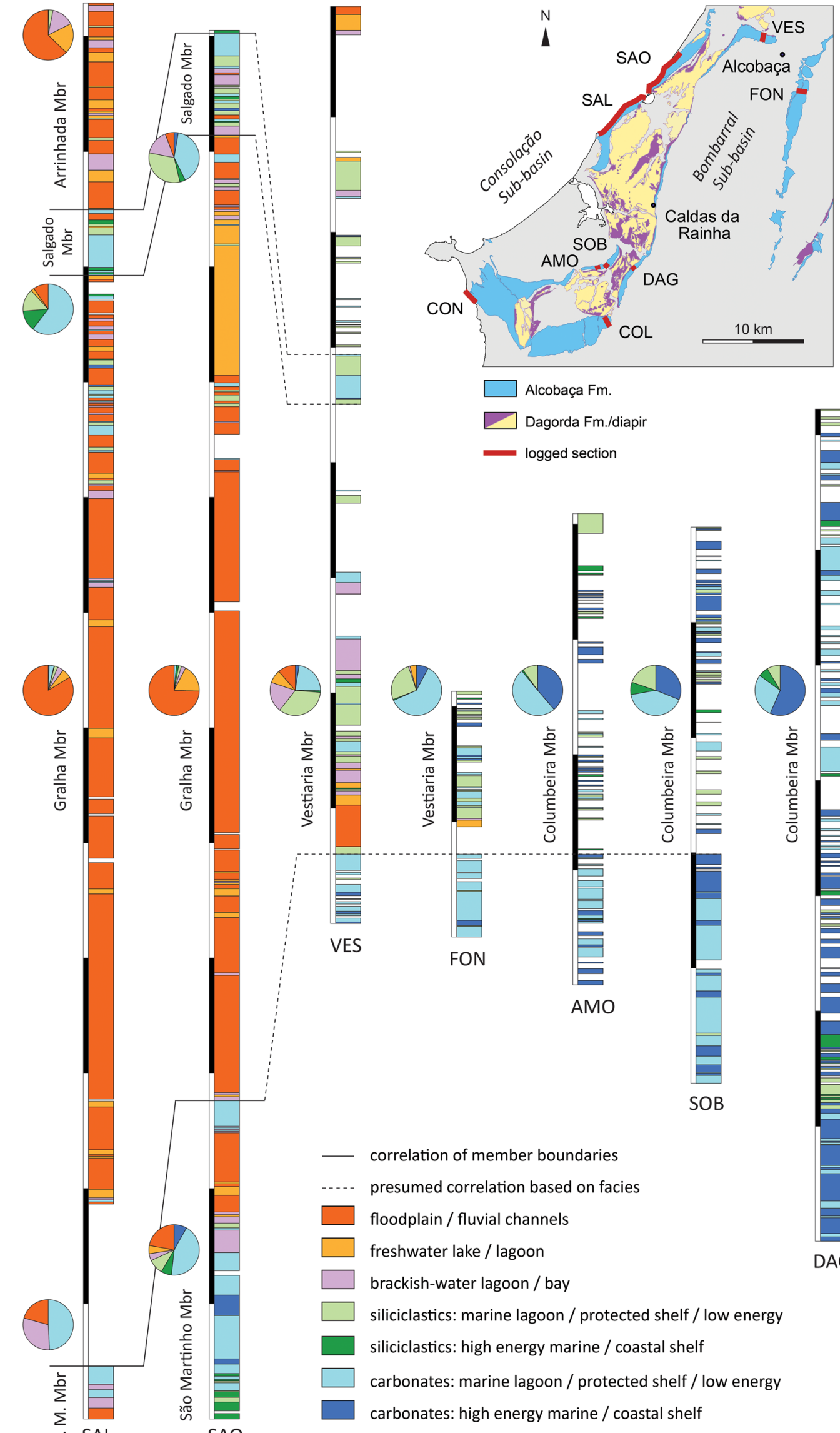

SAL

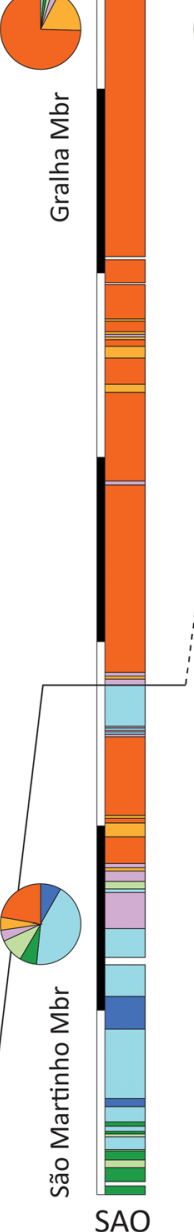

SAO
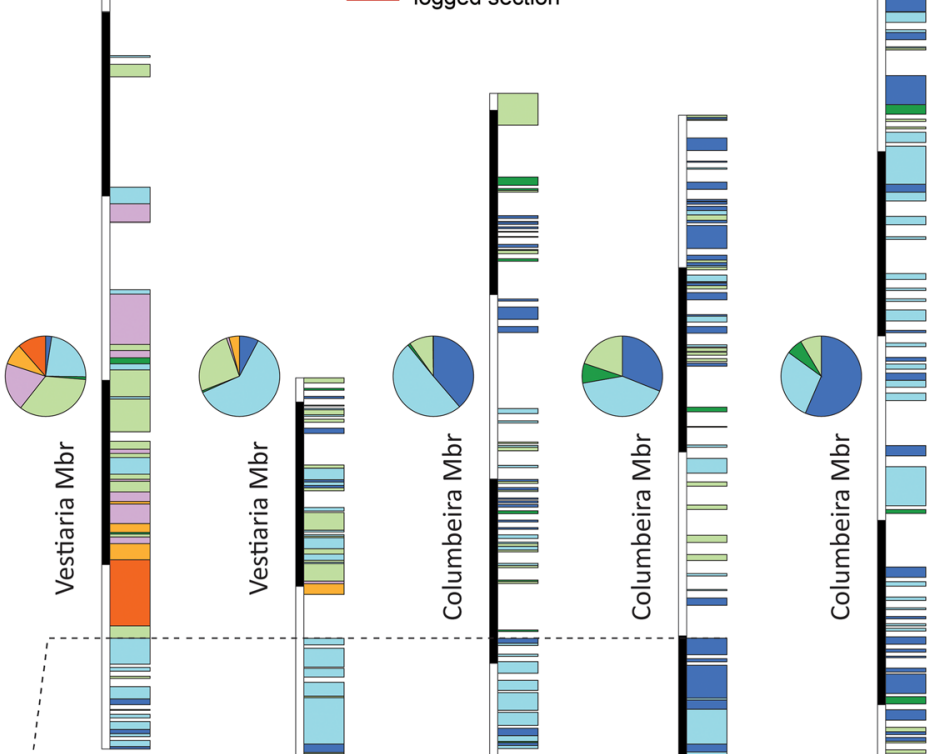

VES
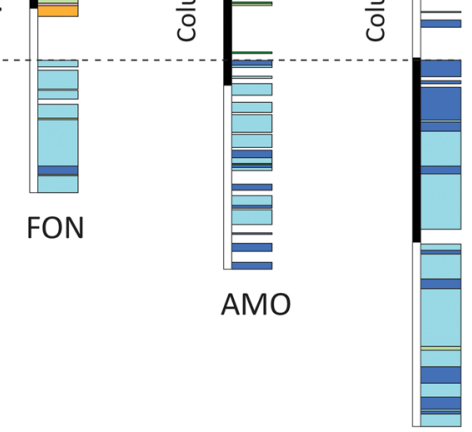

SOB

correlation of member boundaries

.... presumed correlation based on facies

floodplain / fluvial channels

freshwater lake / lagoon

brackish-water lagoon / bay

siliciclastics: marine lagoon / protected shelf / low energy

siliciclastics: high energy marine / coastal shelf

carbonates: marine lagoon / protected shelf / low energy

carbonates: high energy marine / coastal shelf

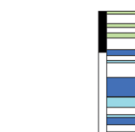

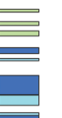

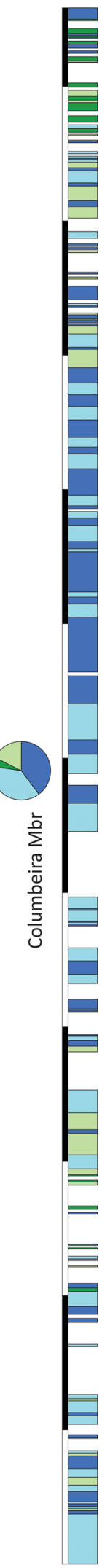

COL 
Fig. 24 Correlation of logged sections, based on depositional environments. Pie charts indicate the proportions of depositional environments in the exposed successions by member. Note that the dashed lines do not indicate member boundaries but rather the inferred laterally equivalent stratigraphic level. $A M O$ Amoreira, $C O L$ Columbeira, CON Consolação, DAG Dagorda, FON Fonte Santa, SAL Salir do Porto, SAO São Martinho do Porto, SOB Sobral da Lagoa, VES Vestiaria

macrofauna. Typical are mixed carbonate and siliciclastic facies, which document the nearshore nature of many of the sediments. This is corroborated by the abundance of brackish-water faunas. However, there also exist thick packages of terrestrial red beds in the northern coastal sections (São Martinho and Salir do Porto) and of platform carbonate rocks in some of the eastern sections (e.g. Columbeira), recording the relative persistence of these general environmental settings (Fig. 24). A simplified depositional model of the Alcobaça Formation is displayed in a block diagram in Fig. 25 and in a schematic cross-section in Fig. 26.
The strongly varying facies pattern reflects, to some extent, climatic changes. Widespread brackish biota accompanied by abundant plant debris, such as in the upper part of the Consolação section and in the Vestiaria section, suggest increased freshwater influx into the basin and point to a humid climate. In contrast, the thick red beds of the coastal sections, with abundant caliche nodules and fluvial sandstones that rarely exceed 2-3 $\mathrm{m}$ in thickness, indicate a semi-arid climate and only limited freshwater input into the basin.

These climatic changes, however, cannot sufficiently explain the facies pattern, in particular the frequent minor fluctuations observed in all sections, which appear to have been decisively controlled by tectonic processes. The Alcobaça Formation occurs in three sub-basins, separated by the Caldas da Rainha Diapir and the Leiria, Porto de Mós and Rio Maior diapirs, respectively. Until recently, the prevailing view was that these diapirs are salt pillows, which started to form during the Early Jurassic, but did not prominently affect

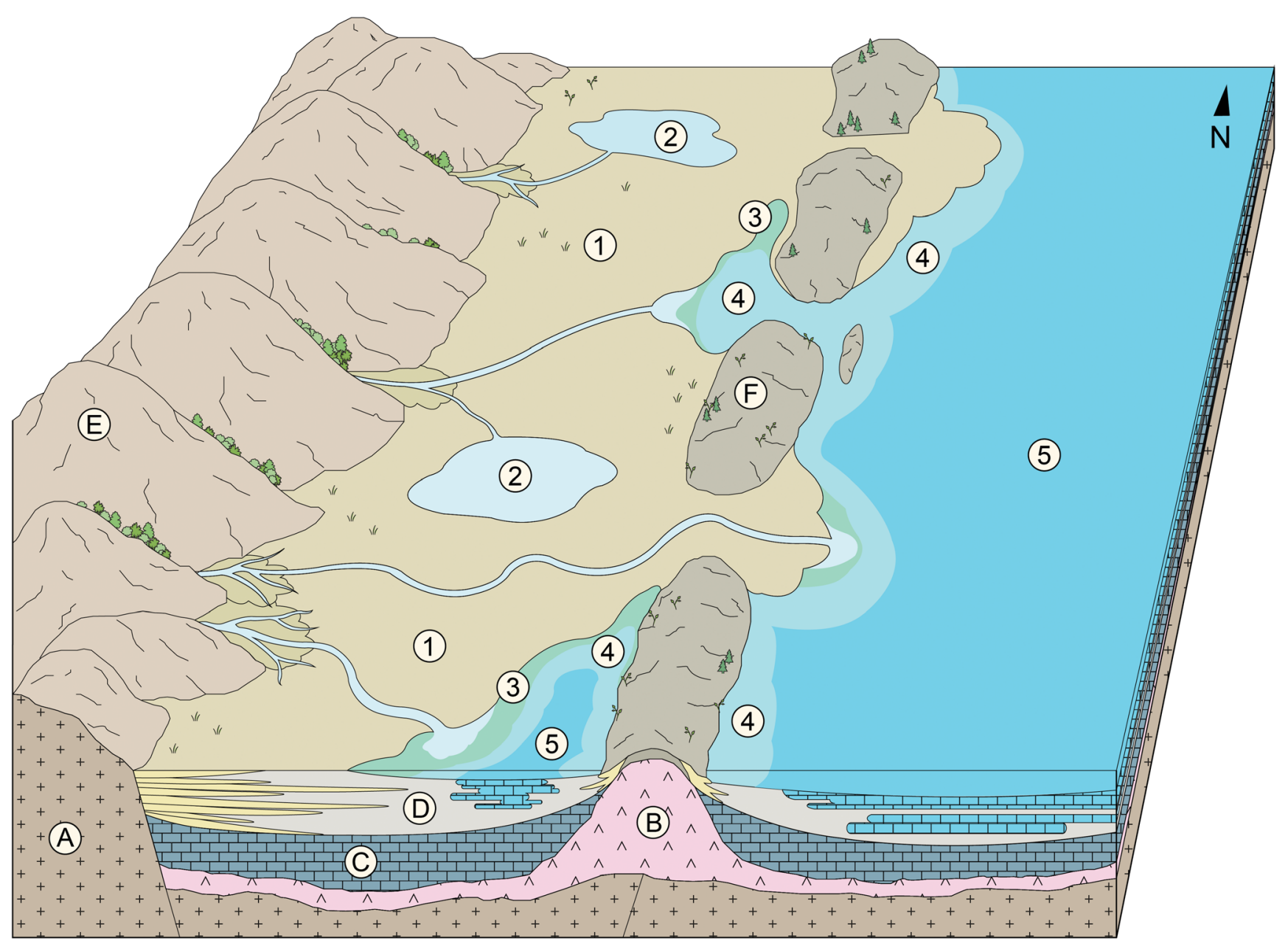

Fig. 25 Schematic depositional model of the Alcobaça Formation in the northern Consolação and western Bombarral sub-basins. $A$ Variscan basement; $B$ latest Triassic/earliest Jurassic salt (Dagorda Fm.); $C$ Early Jurassic to Oxfordian carbonate rocks; $D$ Alcobaça Fm.; $E$ Berlenga Horst Block; $F$ Caldas da Rainha Diapir (emergent passive diapir, with several saddles). Depositional environments/facies: 1 terrestrial, 2 lacustrine, 3 brackish water, 4 marine siliciclastic strata, 5 marine carbonate strata 
GROSS DEPOSITIONAL ENVIRONMENT
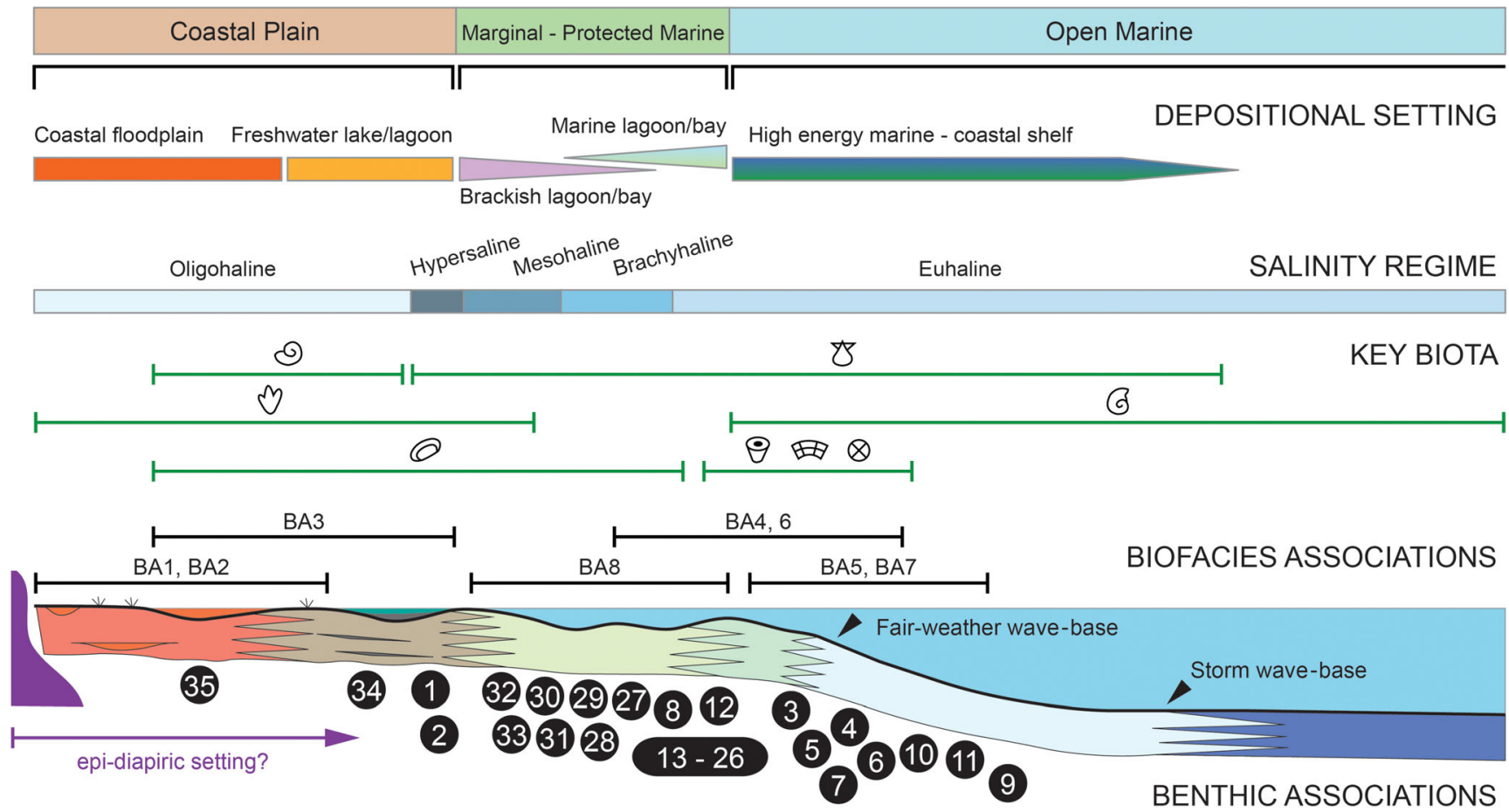

Fig. 26 Schematic cross section illustrating the distribution of gross depositional environments, depositional settings, salinity regimes, key biota (see Fig. 8 for the key of symbols), biofacies associations and benthic macrofaunal assemblages and associations (see Fig. 21 for numbers)

topography before the Late Jurassic, and only pierced the topographic surface during Late Cretaceous to Cenozoic shortening, related to Alpine deformation (e.g. Montenat and Guéry 1984; Guéry et al. 1986; Montenat et al. 1988; Wilson 1988; Ribeiro et al. 1990; Rasmussen et al. 1998; Alves et al. 2002, 2003; Kullberg et al. 2013). This model assumes that a more or less continuous Jurassic sedimentary succession was deposited on top of these pillows and was subsequently eroded (e.g. Wilson 1988; Rasmussen et al. 1998). An instructive example is the block diagram of Montenat et al. (1988: fig. 8), where the Kimmeridgian topography is quite accurately represented, but diapirs play a subordinate role in its interpretation. Recent studies, however, show that this scenario contradicts state-ofthe-art models of salt tectonics and field evidence. It is now established that significant salt movement in the Lusitanian Basin initiated as early as the Early Jurassic, and passive diapirs started to pierce the overburden soon after (e.g. Lopez-Mir et al. 2019, 2020; Davison and Barreto 2020). This model implies that diapir growth kept abreast with sedimentation throughout the Jurassic, and deposition occurred only at the diapir flanks, but not on its crest, which was only covered by a thin veneer of roof strata (Fig. 25; see Hudec and Jackson $(2007,2011)$ and Giles and Rowan (2012) for concepts). This model further suggests that the basal contact of the Alcobaça Formation with the Dagorda Formation, observed in several of the studied sections, while being tectonic in nature, did not cause significant lateral displacement.

Thus, it is reasonable to assume that the Caldas da Rainha Diapir formed a topographic barrier during the Late Jurassic, separating the Consolação Sub-basin to the west from the Bombarral Sub-basin to the east (Figs. 25 and 26). The northwestern part of the Consolação Sub-basin received siliciclastic sediments from the basement exposed on the Berlenga Horst, which formed, either as a chain of islands or as a continuous north-south elongated block, the western margin of the Lusitanian Basin. These fluvial sediments filled a shallow, subsiding graben adjacent to the diapir, which also received minor amounts of sediment shed from the diapir roof strata (Fig. 25). For much of the time, the diapir acted as a barrier so that only locally siliciclastic sediments reached the Bombarral Sub-basin in the east. At other times, marine waters from the Bombarral Sub-basin and the southern Consolação Sub-basin extended westward and northward, respectively, to the western flank of the diapir. The extent to which the diapir acted as a barrier apparently varied considerably throughout the Late Jurassic and was responsible for the frequent alternations and interfingering of non-marine, brackish-water and marine palaeoenvironments on both of its sides. The lower parts of the formation are represented by shallow-marine, high-energy siliciclastic to carbonate facies throughout the study area. They do not suggest a pronounced influence of the diapir on the facies pattern. The following thick package of lacustrine 
and fluvial red beds in the northern coastal sections, which is not present on the eastern side of the diapir, except to a minor extent in the Vestiaria and Fonte Santa sections in the north, likely indicates the piercing of the diapir, which at that time acted as a pronounced barrier. In the upper part of the formation, repeated intercalations of brackish to marine sediments occur in the coastal sections. These document short-lived transgressions of marine waters, either advancing from the Bombarral Sub-basin, crossing the diapir via a saddle, or from the southern Consolação Sub-basin, using the foredeep flanking the diapir as a vector. Subsequently, the predominantly axial siliciclastic influx of the overlying Lourinhã Formation from the north terminated any marine influence in the area.

Evidence that the exposed diapir formed islands with adjacent intertidal to supratidal areas is also provided by the presence of common black pebbles, microkarst and dinosaur tracks in the Sobral da Lagoa and Amoreira sections. The dinosaurs must have crossed the coastal plains between the hills forming the western margin of the Lusitanian Basin and the emergent diapirs during periods of low water level and arid conditions and inhabited coastal areas while marine conditions prevailed. The exposed parts of the diapir also must have undergone erosion and supplied sediment to the Consolação and Bombarral sub-basins, but the quantity of this material is difficult to evaluate.

Marine to brackish-water areas on both sides of the diapir were populated by diverse macrobenthic communities (Fig. 26). In brackish lagoons and bays, bivalve-dominated communities lived, whose generally low diversity varied according to their salinity regime. These faunas were most prolific in the Consolação, Salir do Porto and São Martinho do Porto sections. Their dominance decreased in the Vestiaria and Fonte Santa sections, whereas in the remaining, carbonate-dominated sections, they are absent. The lowermost carbonate beds at Salir do Porto and São Martinho do Porto contain Isognomon-Actinostreon-dominated associations that most likely lived in slightly hypersaline environments (Fig. 26). This might reflect a relatively arid climate at that time. In the carbonate-dominated sections, corals and stromatoporoids are common elements. Corals and, in some cases, calcareous sponges, however, form patch reefs mainly in mixed carbonate-siliciclastic successions, settling on bioclastic detritus. This kind of substrate is also characteristic of the widespread coral meadows in the lower part of the Consolação section. The more pronounced marine influence in the southern sections seems to reflect a reduced influence of diapirism during the Kimmeridgian. This appears to have also been the case in the later part of the Kimmeridgian, when marine influence increased again throughout the study area.

Given that we did not study the succession in the Mamede Sub-basin in detail, it is unclear how much the Leiria, Porto de
Mós and Monte Real diapirs acted as a barrier. It should be noted, though, that both shallow-marine carbonate rocks and fine-grained freshwater to brackish-water siliciclastic strata were observed in the area of Abiul, signifying a range of lithofacies and biofacies similar to those observed in the other sub-basins.

The Alcobaça Formation as a model for biofacies analysis

Naturally, such detailed analysis of a single lithostratigraphic unit primarily advances the understanding of the conditions within the Lusitanian Basin. However, the Alcobaça Formation is particularly well exposed in several coastal sections and was so in the past at a number of localities inland. Furthermore, its fossil biota is remarkably well preserved over most of the succession. This made it possible to generate an outstanding dataset, which demonstrates the power of detailed biofacies analysis for disentangling a complex patchwork of palaeoenvironments. The observed interplay of sea-level fluctuations, climate changes and salt tectonics is not unique to the Lusitanian Basin. Units occupying a similar position at the interface of land and sea, thus showing a similar variability in biofacies, occur in numerous sedimentary basins, and the general approach applied to the Alcobaça Formation herein is transferrable.

Adjacent Atlantic basins, which are less well or not at all exposed, (presumably) show similar characteristics at a similar time, and biofacies of well materials, if available, could be directly compared. The Peniche Basin is situated directly to the west of the Lusitanian Basin, the Porto Basin to the north, the Galicia Basin to the northwest and the Alentejo Basin to the south. These basins are all part of the same continental margin, now entirely submerged, or almost so. Where available, scant evidence from wells and dredging documents lithologies and palaeoenvironments similar to those seen in the Lusitanian Basin (Boillot et al. 1973, 1974, 1975; Dupeuble et al. 1987). Moreover, seismic data, in particular from the Peniche Basin, suggest an evolutionary development comparable to that of the Lusitanian Basin, with salt tectonics playing an equally important role (Pinheiro et al. 1996; Alves et al. 2006, 2009; Pimentel and Pena dos Reis 2016; Walker et al. 2021).

Farther to the south, the Algarve Basin in southern Portugal and adjacent Spain is also influenced by diapirism but generally has a more marine, carbonate-dominated character (Terrinha et al. 2002; Borges et al. 2011; Matias et al. 2011; Fernandes et al. 2013). However, marginal marine environments with faunas similar to that of the Alcobaça Formation are represented in the basin (Pratsch 1958) but are probably understudied. In the Asturias Basin in northwestern Spain, a single comprehensive coastal outcrop of the late Oxfordian to early Tithonian Ribadasella Group exposes a number of biofacies similar to those observed in the Lusitanian Basin, 
but seems to have a less intricate palaeoenvironmental development (Fürsich et al. 2012; González Fernández et al. 2014). Interestingly, significant thickness variations of Upper Jurassic strata in the subsurface (Boillot et al. 1979; Boillot and Malod 1988; Cadenas and Fernández-Viejo 2016) indicate a more complex development at the basin scale and suggest that tectonic processes, including diapirism, may have been neglected so far. At the conjugate western Atlantic margin, several basins offshore Newfoundland, including the Jeanne d'Arc, Flemish Pass, Orphan and Carson-Salar basins, have depositional histories similar to western Iberia (e.g. Stam 1986; Williamson 1987; McAlpine 1990). Being active hydrocarbon exploration areas, as increasing amounts of well materials become available from these basins, biofacies analysis may help to interpret their evolution.

The integrated approach documented here is limited only by the quality of the fossil record, not by geography or stratigraphy. It is thus globally applicable to constraining compartmentalisation in salt-floored basins.

\section{Conclusions}

1. The Alcobaça Formation is formally established as a lithostratigraphic unit of the central Lusitanian Basin. Its age is Kimmeridgian (late Bimammatum Zone to Beckeri Zone), based on ammonites, ostracods and strontium stable isotopes.

2. Seven members are established in the Bombarral and Consolação sub-basins (see Appendix), ranging across a spectrum from siliciclastic- to carbonate-dominated, whereby mixed carbonate-siliciclastic facies are characteristic.

3. The Alcobaça Formation captures a diverse range of depositional environments, from fluvial and coastal plain settings to marginal marine lagoons and embayments, and to the shallow-water shelf above storm wave-base.

4. Apart from common ostracods and foraminifera, the formation contains a rich benthic macrofauna dominated by bivalves, and an ichnofauna (including dinosaur tracks) representing the Scoyenia, Skolithos and Cruziana ichnofacies. Index fossils such as ammonites are very scarce.

5. Thirty-five benthic macrofaunal associations have been recognised, controlled mainly by water energy, substrate and salinity. Salinity-controlled associations occupied hypersaline to freshwater environments. The salinity regime of the associations has been determined based on sedimentological and ecological (species richness and evenness) parameters, species composition, comparison with modern relatives, the associated microfauna and microflora and morphological features such as shell thickness and shell size. Patch reefs and meadows mainly composed of corals, but locally also of calcareous sponges, or, in brackish environments, of oysters, occur at several levels.

6. To the west, in the northern Consolação Sub-basin, siliciclastic and often non-marine sediments dominate, whereas in the Bombarral Sub-basin farther to the east, thick carbonate successions prevail. Widespread terrestrial red beds with caliche and hypersaline carbonate facies in the lower part of the succession point to a semi-arid climate, which appears to have changed to more humid conditions near the top of the formation.

7. During Kimmeridgian times, the Caldas da Rainha Diapir, which started to rise as early as the Early Jurassic, formed an emergent topographic barrier, separating the northwestern part from the southeastern part of the basin. The western Consolação Sub-basin likely received siliciclastic sediments from Berlenga and adjacent basement horsts that formed the western margin of the Lusitanian Basin. These sediments only locally at times reached the areas east of the diapir, which were dominated by carbonate depositional systems. Brackish, marginal marine environments were common on both sides of the diapir.

8. The Alcobaça Formation, characterised by intricate facies patterns and varied biota, illustrates the impact of diapirism on the palaeogeography, facies and organisms of shallow-water basins such as the Lusitanian Basin. It forms an insightful analogue for adjacent Atlantic marginal basins and for elsewhere in the geological record. Detailed biofacies analysis of the unit is shown to be a powerful tool to analyse and disentangle the palaeoenvironmental development of such variable successions and, last not least, to subdivide them into meaningful lithostratigraphic units.

\section{Appendix. Formal definition of the Alcobaça Formation}

Derivation of name: From the city and municipality of Alcobaça, Oeste Subregion, Central Portugal.

Superior units: None. The proposed Estremadura Group of Witt (1977) and the Abadia Group of Leinfelder (1986) have never come into use.

First description: As Couches d'Alcobaça by Choffat (1885: 5, 18).

Chronostratigraphy: Earliest to latest Kimmeridgian (sensu Wierzbowski et al. 2016).

Synonyms: Couches d'Alcobaça = Camadas de Alcobaça = Alcobaça Beds (Choffat 1885; Zbyszewski and Moitinho de Almeida 1960; Ruget-Perrot 1961; Camarate França and Zbyszewski 1963, among others). Couches à Lima alternicosta, pro parte (Choffat 1885). Couches à Lima 
pseudo-alternicosta $=$ Camadas com Lima pseudoalternicosta, pro parte? (Choffat 1901; Camarate França and Zbyszewski 1963, among others). Abadia Beds = Camadas de Abadia, pro parte (Camarate França et al. 1960; Manuppella et al. 1978; Wilson 1979). Camadas de Montejunto $=$ Montejunto Formation, pro parte $($ Camarate França and Zbyszewski 1963; Mocho et al. 2017). Guimarota beds = Camadas de Guimarota $=$ GuimarotaSchichten (Helmdach 1968, 1971a, b, among others). Pholadomya protei Beds = Camadas com Pholadomya protei, pro parte (Wilson 1975, 1979; Bernardes et al. 1991). Vale Verde Beds = Camadas de Vale Verde, pro parte (Wilson 1979; Bernardes et al. 1991). 'Corallien/ Sobral of Parant (1963)' (Wilson 1979). Complexo de Vale de Lagares (Teixeira and Zbyszewski 1968). Formação Argilosa de S. Martinho do Porto (Bernardes et al. 1991). Reguengo Pequeno Subunit $=$ Calcários calciclásticos com oóides, margas e grés de Reguengo Pequeno (Manuppella 1998; Manuppella et al. 1999). Moledo Subunit $=$ Calcários de Moledo (Manuppella 1998; Manuppella et al. 1999). Consolação Member = Consolação Subunit $=$ Grés, margas, calcários oolíticos e dolomites da Consolação = Consolação Formation (Leinfelder 1986; Manuppella 1998; Manuppella et al. 1999; Mocho et al. 2017; Castanera et al. 2020a, b). Calcários bioclásticos com corais e calcários oolíticos de Feteira (Manuppella et al. 1999). Margo-calcários de Abiúl $=$ Formação de Abiúl = Membro de Abiúl (Almeida et al. 1990; Kullberg et al. 2013; Kullberg and Rocha 2014). Lithology: Characteristically highly variable. Carbonate rocks include marly, silty, sandy and rarely also pure mudstone; (mixed) (sandy) intraclastic, ooidal, oncoidal and bioclastic wackestone; (mixed) (sandy, silty or marly) intraclastic, oncoidal and bioclastic floatstone; silty ooidal wackestone; (mixed) sandy intraclastic, ooidal, oncoidal and bioclastic packstone; (mixed) (sandy) intraclastic, ooidal, oncoidal and bioclastic grainstone; (mixed) (sandy, marly) ooidal, oncoidal and bioclastic rudstone; oncolitic marlstone; coral boundstone; (silty, sandy, bioclastic) algal bindstone; and (sandy, silty) marl. Siliciclastic rocks include (silty, sandy) mudstone; (marly, argillaceous, sandy) (bioclastic, oolitic or oncolitic) siltstone; and (calcareous, marly, silty) (bioclastic, oolitic or oncolitic) fine- to coarse-grained sandstone. Rarely, coal layers and conglomerates consisting of caliche nodules occur.

Characteristic biota: Corals and coral meadows; marine and brackish-water bivalves, including abundant bakevelliids, pteriids and neomiodontids, common shell concentrations of Isognomon, Actinostreon and Trichites, as well as Praeexogyra patch reefs; marine and freshwater gastropods, including nerineids and valvatids; echinoids, predominantly abundant spines of Pseudocidaris; calcareous sponges, stromatoporoids, red algae and algal laminites; diverse ichnofauna including Psilonichnus, Rhizocorallium, Thalassinoides, Scoyenia and dinosaur tracks.

Depositional environments: Marine: shallow, high- to lowenergy open marine shelf, predominantly above fair-weather wave-base; shallow protected shelf below fair-weather wavebase; shoals, bars and channels; marine lagoons. Transitional: slightly hypersaline, brackish-water and freshwater lagoons and protected embayments. Freshwater: very shallow freshwater lakes and swampy areas; floodplain with overbank deposits; coastal plain; channels and levees of predominantly straight-headed streams.

Subunits: Seven members, which are defined below: the Consolação Member (proposed but not formalised by Leinfelder 1986), and the São Martinho, Gralha, Salgado, Arrinhada, Vestiaria and Columbeira members proposed here.

Two informal subunits introduced by Manuppella (1998) and Manuppella et al. (1999), i.e. the Reguengo Pequeno Subunit $=$ Calcários calciclásticos com oóides, margas e grés de Reguengo Pequeno and the Moledo Subunit $=$ Calcários de Moledo (Manuppella 1998; Manuppella et al. 1999) are poorly described and not supported by logs. The same applies to the Calcários bioclásticos com corais e calcários oolíticos de Feteira (Manuppella et al. 1999), which are referred to as the Alcobaça Formation herein, based on their lithology and fossil content. Outcrop in the respective area, at the southern slope of the Serra d'El Rei (Bombarral Sub-basin), is extremely poor, preventing a comprehensive log to be compiled (personal observation, June 2016).

The Margo-calcários de Abiúl = Formação de Abiúl = Membro de Abiúl (Almeida et al. 1990; Kullberg et al. 2013; Kullberg and Rocha 2014), which are restricted to a small area in the northwestern Mamede Sub-basin, east of Pombal, are similarly poorly described and exposed. The lithologies and biota observed conform to the general description of the Alcobaça Formation above (personal observation, June 2016). Whether the succession near Abiul has member status remains to be established. Farther to the south in the Mamede Sub-basin, the Complexo de Vale de Lagares of Teixeira and Zbyszewski (1968), cropping out in the area around the Vimeiro Diapir (Fig. 1: 6), conforms to the general description of the Alcobaça Formation but has not been studied by the present authors; its member status remains unassessed.

The 'Praia da Amoreira-Porto Novo Subunit' of Manuppella (1998) = 'Grés margas e arenitos da Praia da Amoreira-Porto Novo' of Manuppella et al. (1999) = 'Praia da Amoreira-Porto Novo Formation' of Mocho et al. (2017), which was assigned to the Alcobaça Formation by these authors, is considered part of the Lourinhã Formation herein.

Lower boundary: If undisturbed, the Alcobaça Formation overlies pure limestones of the Montejunto Formation. The contact is sharp and potentially represents a paraconformity. 
The onset of the Alcobaça Formation is marked by the first level where siliciclastic influence becomes obvious, either as substantial admixtures of sand in the carbonate or in the form of siliciclastic horizons. In several sections, however, the Alcobaça Formation unconformably overlies clays, marls and anhydrites of the Dagorda Formation. The contact is tectonic but probably was so very early on, due to the diapiric activity.

Upper boundary: The Alcobaça Formation is overlain by fluvial-deltaic sandstones of the Lourinhã Formation. The contact is conformable and generally gradual. The upper boundary is defined as the level above which thick-bedded fluvial-deltaic sandstones, generally nested within stacked channel complexes, become dominant and euryhaline deposits are absent.

Thickness: Probably rather variable; minimum thickness approximately $400 \mathrm{~m}$; maximum thickness greater than $600 \mathrm{~m}$. Type and reference sections, type region: The Vestiaria section, situated along the road from Fervença to Vestiaria, NW of the village (39.56882, -9.00305 to $39.56228,-9.00716$; described in detail above), is selected as the stratotype of the Alcobaça Formation herein. The succession most closely conforms to the original Couches d'Alcobaça sensu Choffat (1885: 5, 18), which were described from near Fervença.

In the Vestiaria section, the top of the Alcobaça Formation is positioned at the base of a several-metres-thick fluvial sandstone bed, signalling the onset of the overlying Lourinhã Formation. However, the basal contact of the Alcobaça Formation with the underlying Dagorda Formation is tectonic in nature. The Fonte Santa section, just over $7 \mathrm{~km}$ to the southeast (road section near 39.52335, -8.95225), is the only comprehensive section exposing the paraconformable (?) basal contact of the Alcobaça Formation with the underlying Montejunto Formation and is thus selected as an additional reference section.

The western and eastern Bombarral Sub-basin and the eastern Consolação Sub-basin, where the sections studied herein are located, are considered the type region of the Alcobaça Formation. Owing to the heterogeneity of the unit, the type sections of the other six members defined below are all considered additional reference sections for the Alcobaça Formation.

Distribution: (A) Consolação Sub-basin, coastal exposures from south of Nazaré to Lagoa de Óbidos (sheets 26B Alcobaça, 26D Caldas da Rainha). (B) Consolação Sub-basin, coastal exposures at Consolação (sheet 26C Peniche). (C) Bombarral Sub-basin, western margin: eastern flank of Caldas da Rainha Diapir, between Rio Alcôa and Moledo (sheets 26B Alcobaça, 26D Caldas da Rainha, 30A Lourinhã, 30B Bombarral). (D) Bombarral Sub-basin, eastern margin: western flanks of Serra d'Aire, Serra de Porto de Mós and Serra dos Candeeiros, between Batalha and Rio Maior (sheets 26B Alcobaça, 26D Caldas da Rainha, 27A Vila
Nova de Ourém). (E) Mamede Sub-basin, western flank of Serra de Sico, between Pombal and Abiul (Carta geológica de Portugal, 1:50,000, sheet 23A Pombal). (F) Mamede Sub-basin, Vermoil and surroundings (sheet 23C Leiria). (G) Mamede Sub-basin, western flank of Serra d'Aire, Batalha and Porto de Mós (sheets 23C Leiria, 27A Vila Nova de Ourém). (H) Mamede Sub-basin, west of Ourém (sheet 27A Vila Nova de Ourém).

Time-equivalent units: Abadia Formation; Amaral Formation; Lourinhã Formation pro parte.

Age: Basal Kimmeridgian (late Bimammatum Zone; $156.9 \pm 6 \mathrm{Ma}$ ) to latest Kimmeridgian (Beckeri Zone; $152.5 \pm 5 \mathrm{Ma}$ ), based on strontium isotope stratigraphy (ages revised from Schneider et al. 2009, after Wierzbowski et al. 2017). Early Kimmeridgian (Planula/Platynota zones boundary interval) to earliest Tithonian (Hybonotum Zone), based on ammonite biostratigraphy (Werner 1986; Marques et al. 1992; Manuppella et al. 1999; herein). The earliest Tithonian age reported by Marques et al. (1992) for the highest part of the unit, which is deduced from the presence of Hybonoticeras sp., remains poorly supported and controversial. A basal to latest Kimmeridgian age is thus assumed herein (see "Revised age model").

\section{Members of the Alcobaça Formation}

Due to its heterogeneity, the Alcobaça Formation is subdivided into seven lithologically and palaeoenvironmentally distinct members, which are defined in the following. For more detailed characterisations of the type sections, see "Section summaries".

\section{Consolação Member}

Derivation of name: From the village of Consolação, south of Peniche.

First description: Section described in detail by Werner (1986); name proposed, but not formalised by Leinfelder (1986).

Synonyms: Consolação Subunit = Grés, margas, calcários oolíticos e dolomites da Consolação = Consolação Formation (Manuppella 1998; Manuppella et al. 1999; Mocho et al. 2017).

Type section: Coastal cliffs west and southwest of Consolação (39.32457, -9.36151 to $39.31232,-9.34679)$.

Lithology: Partly shelly calcareous sandstones and silty marl in the lower part; argillaceous silts, marly siltstones with intercalated fine- to coarse-grained sandstones in the upper part. Lower boundary: Base of unit not exposed.

Upper boundary: Top of marly siltstones, overlain by thick fluvial sandstones of the Lourinhã Formation.

Thickness: $198 \mathrm{~m}$. 
Characteristic biota: Diverse coral meadows; benthic associations dominated by bakevelliid and pteriid bivalves; brackish-water softground associations; Praeexogyra patch reefs.

Depositional environment: Fully marine shallow shelf to nearshore salinity-controlled environments.

Distribution: Known from the type section only.

\section{São Martinho Member}

Derivation of name: From the parish of São Martinho do Porto.

First description: Logs published by Wilson (1979) and Bernardes et al. (1991).

Synonyms: Camadas de Montejunto, pro parte (Camarate França and Zbyszewski 1963). Pholadomya protei Beds = Camadas com Pholadomya protei, pro parte (Wilson 1975, 1979; Bernardes et al. 1991). Vale Verde Beds = Camadas de Vale Verde, pro parte (Wilson 1979; Bernardes et al. 1991). Type section: Coastal cliffs at northern spur of Bay of São Martinho do Porto $(39.51042,-9.14357$ to approximately 39.51373, -9.14144).

Lithology: Basal $13 \mathrm{~m}$ fine- to medium-grained sandstones followed by fossil-rich wackestone to grainstone. After a 53-m-thick intercalation of fine-grained siliciclastic beds, the member concludes with a 12-m-thick sandy carbonate unit.

Lower boundary: The basal contact of the sandstones with the underlying Dagorda Formation is tectonic in nature; basal part of unit brecciated.

Upper boundary: Top of last carbonate bed of the second carbonate unit (Fig. 9 at $137 \mathrm{~m}$ ), overlain by fine-grained siliciclastic beds of Gralha Member.

Thickness: $137 \mathrm{~m}$ (type section).

Characteristic biota: Shell concentrations dominated by Isognomon, Actinostreon and Trichites; algal laminites.

Depositional environment: Nearshore marine sandy shoals; brackish, marine to slightly hypersaline lagoons; coastal plain with fluvial channels.

Distribution: Known from the São Martinho do Porto and Salir do Porto sections.

Gralha Member

Derivation of name: From Praia da Gralha (Gralha Beach), north of São Martinho do Porto.

First description: Logs published by Wilson (1979) and Bernardes et al. (1991).

Synonyms: Abadia Beds, pro parte (Wilson 1979). Formação Argilosa de S. Martinho do Porto, originally proposed in an unpublished $\mathrm{PhD}$ thesis by Ellwood (1987), cited but not formalised by Bernardes et al. (1991).
Type section: Coastal cliffs north of São Martinho do Porto (approximately $39.51373,-9.14144$ to $39.53606,-9.1252$ ).

Lithology: Predominantly reddish argillaceous-marly silt with caliche nodules and with intercalated fine- to coarsegrained sandstones; some sandy limestone intercalations in the upper $120 \mathrm{~m}$.

Lower boundary: Onset of fine-grained siliciclastic strata, following the last carbonate complex of the São Martinho Member (Fig. 9 at $137 \mathrm{~m}$ ).

Upper boundary: Top of last thick red bed unit (Fig. 9 at $558 \mathrm{~m}$ ), overlain by marlstones and limestones of the Salgado Member.

Thickness: $422 \mathrm{~m}$ (type section) to approximately $480 \mathrm{~m}$.

Characteristic biota: Red beds unfossiliferous except Scoyenia; grey fine-grained siliciclastic strata with freshwater gastropods. Limestone intercalations with Psilonichnus, Rhizocorallium and Thalassinoides and a moderately diverse mollusc and coral fauna.

Depositional environment: Floodplain with fluvial channels; brackish-water lagoons; coastal lakes. Rare marine incursions. Distribution: Known from the São Martinho do Porto and Salir do Porto sections.

Salgado Member

Derivation of name: From the village of Casal do Salgado, south of Nazaré, and the adjacent Praia do Salgado (Salgado Beach).

First description: Logs published by Wilson (1979) and Bernardes et al. (1991).

Synonyms: 'Corallien/Sobral of Parant (1963)' (Wilson 1979); this term incorrectly refers to an unpublished report of the Companhia Portuguesa dos Petróleos (CPP) by Parant (1963).

Type section: Coastal cliffs WSW of Casal do Salgado (approximately $39.539151,-9.121526)$.

Lithology: Mixed carbonate-siliciclastic strata, minor red bed intercalations; some fine-grained sandstones; common oncoidal floatstones to rudstones.

Lower boundary: Onset of marlstones and limestones following the last thick red bed unit of the Gralha Member (Fig. 9 at $558 \mathrm{~m}$ ).

Upper boundary: Top of marine sandstone, overlain by nonmarine siliciclastic beds of the Arrinhada Member (Fig. 9 at $605 \mathrm{~m})$.

Thickness: 25 to $44 \mathrm{~m}$ (type section).

Characteristic biota: Scattered corals and stromatoporoids; marine bivalves and gastropods; diverse ichnofauna including dinosaur tracks.

Depositional environment: Very shallow, largely protected nearshore shelf, marine to brackish lagoons; coastal plain.

Distribution: Known from the São Martinho do Porto and Salir do Porto sections. 
Arrinhada Member

Derivation of name: From the Miradouro da Arrinhada (= lookout of Arrinhada), halfway between Salir do Porto and Foz do Arelho.

First description: Herein.

Synonyms: None.

Type section: Coastal cliffs W of village of Boavista, SW of Salir do Porto (approximately 39.477073, -9.194230).

Lithology: Mainly reddish argillaceous/marly sandy silt with caliche nodules and intercalations of fine- to coarse-grained, partly cross-bedded sandstones; desiccation cracks and rootlets.

Lower boundary: Onset of siliciclastic strata on top of last carbonate bed of the carbonate-prone Salgado Member (Fig. 10 at $535 \mathrm{~m}$ ).

Upper boundary: Top of fine-grained, relatively low-energy brackish-water siliciclastic strata, overlain by grey coarsegrained sandstone with abundant logs of fossilised wood of the Lourinhã Formation (Fig. 10 at $523 \mathrm{~m}$ ).

Thickness: $88 \mathrm{~m}$ (type section).

Characteristic biota: Freshwater gastropods; Scoyenia, Polycladichnus and Psilonichnus.

Depositional environment: Mainly floodplain with fluvial channels; small lakes; brackish to freshwater lagoons.

Distribution: Known from the Salir do Porto and São Martinho do Porto sections; barely exposed in the latter.

\section{Vestiaria Member}

Derivation of name: From the parish of Vestiaria W of Alcobaça.

First description: Locality of Fervença mentioned by Choffat (1885: 5, 18). Position of the Vestiaria section of Marques et al. (1992) unclear; not identical with the section described herein.

Synonyms: None.

Type section: Road from Fervença to Vestiaria, $\mathrm{N}$ of village of Vestiaria (39.56882, -9.00305 to $39.56228,-9.00716)$.

Lithology: Reddish fine- to medium-grained sandstones, argillaceous/marly sandy silt, silty/sandy mudstone, marl; rare intraclastic grainstone; interlayered bedding.

Lower boundary: Onset of marine carbonate strata over reddish-purplish marls of the Dagorda Formation; contact tectonically distorted.

Upper Boundary: Top of fine-grained non-marine siliciclastic beds, overlain by coarse-grained fluvial sandstones of the Lourinhã Formation (Fig. 12, at 399 m).

Thickness: 399 m (type section; upper part poorly exposed). Characteristic biota: Coral meadows, coral and coral-sponge patch reefs; freshwater gastropods; diverse marine benthic macrofauna.
Depositional environment: Fluvial channels; small lakes; brackish, partly tidal-influenced lagoons and fully marine coastal environments.

Distribution: Known from the Vestiaria and Fonte Santa sections and adjacent areas, including the localities of Barrio, Chiqueda and Carrascal.

Columbeira Member

Derivation of name: From the village of Columbeira, NW of Bombarral.

First description: Herein.

Synonyms: None.

Type section: Road from Azambujeiras dos Carros to Columbeira (approximately $39.29165,-9.19146$ to $39.30282,-9.18704)$.

Lithology: Lower and upper part an alternation of sandy carbonate beds, marl and silty marl with minor sandstone intercalations and abundant lignite fragments; upper part in addition with common oncoids; middle part mainly intraclastic and ooidal wackestones to grainstones and oncoidal rudstones (Fig. 14). Several levels with dissolution cavities.

Boundaries: Base and top of member not seen.

Thickness: Greater than $576 \mathrm{~m}$.

Characteristic biota: Red algae, stromatoporoids, corals, sponges, and echinoid fragments.

Depositional environment: Shallow to very shallow, occasionally emerged, marine carbonate platform composed of restricted and exposed areas.

Distribution: Known from the Columbeira, Dagorda, Amoreira and Sobral da Lagoa sections and adjacent areas.

Acknowledgements The following persons are gratefully acknowledged for providing manifold support during the preparation of this study. FriedrichFranz Helmdach and Michael Schudack (both deceased; both formerly Freie Universität Berlin, Germany) provided determinations of ostracods. Manja Hethke (Freie Universität Berlin, Germany) supplied literature. Laura Mitchell (CASP, Cambridge, UK) digitised the geological maps for Fig. 3. Martin Nose (SNSB-BSPG, Munich, Germany) assisted in the field and engaged in the discussion of carbonate microfacies. Beth O'Connel (University of Cambridge, UK) assisted in the field and with the microfossil analysis. Miguel M. Ramalho (Geological Museum Lisbon, Portugal) organised permits for fieldwork, provided determinations of foraminifera and ostracods and helped with the curation of figured material. Gerhard Schairer (deceased; formerly SNSB-BSPG, Munich, Germany) and Günter Schweigert (Staatliches Museum für Naturkunde, Stuttgart, Germany) provided the ammonoid determinations and biostratigraphy. Over the years, various technicians in the joint preparation lab of the SNSB-BSPG and the Palaeontology Section of the Ludwig-Maximilians-University Munich prepared thin sections. Li Guo and Stephen Vincent (both CASP, Cambridge, UK) commented on an earlier draft of the manuscript. Constructive and insightful reviews by Ana Cristina Azerêdo (Department of Geology, University of Lisbon, Portugal) and Martin Nose (SNSB-BSPG, Munich, Germany) helped to improve the study.

Funding Open access enabled and organized by Projekt DEAL. The study received funding of the NAME Project from CASP's industry 
sponsors. Part of the fieldwork was financially supported by the Deutsche Forschungsgemeinschaft (grant no. Fu 131/5-1).

\section{Declarations}

Conflict of interest The authors declare no competing interests.

Open Access This article is licensed under a Creative Commons Attribution 4.0 International License, which permits use, sharing, adaptation, distribution and reproduction in any medium or format, as long as you give appropriate credit to the original author(s) and the source, provide a link to the Creative Commons licence, and indicate if changes were made. The images or other third party material in this article are included in the article's Creative Commons licence, unless indicated otherwise in a credit line to the material. If material is not included in the article's Creative Commons licence and your intended use is not permitted by statutory regulation or exceeds the permitted use, you will need to obtain permission directly from the copyright holder. To view a copy of this licence, visit http://creativecommons.org/licenses/by/4.0/.

\section{References}

Almeida, A. C. d., Soares, A. F., Cunha, L., \& Marques, J. F. (1990). Proémio ao estudo do Baixo Mondego. Biblos, 46, 17-47.

Alves, T. M., Gawthorpe, R. L., Hunt, D. W., \& Monteiro, J. H. (2002). Jurassic tectono-sedimentary evolution of the northern Lusitanian Basin (offshore Portugal). Marine and Petroleum Geology, 19, 727-754.

Alves, T. M., Manuppella, G., Gawthorpe, R. L., Hunt, D. W., \& Monteiro, J. H. (2003). The depositional evolution of diapir- and fault-bounded rift basins: Examples from the Lusitanian Basin of West Iberia. Sedimentary Geology, 162, 273-303.

Alves, T. M., Moita, C., Sandnes, F., Cunha, T., Monteiro, J. H., \& Pinheiro, L. M. (2006). Mesozoic-Cenozoic evolution of North Atlantic continental-slope basins; the Peniche Basin, western Iberian margin. AAPG Bulletin, 90, 31-60.

Alves, T. M., Moita, C., Cunha, T., Ullnaess, M., Myklebust, R., Monteiro, J. H., \& Manuppella, G. (2009). Diachronous evolution of Late Jurassic-Cretaceous continental rifting in the Northeast Atlantic (west Iberian margin). Tectonics, 28(TC4003), 1-32.

Azerêdo, A. C. (2007). Formalização da litostratigrafia do Jurássico Inferior e Médio do Maciço Calcário Estremenho (Bacia Lusitânica). Comunicações Geológicas, 94, 29-51.

Azerêdo, A. C., Duarte, L. V., Henriques, M. H., \& Manuppella, G. (2003). Da dinâmica continental no Triásico aos mares do Jurássico Inferior e Médio. Cadernos de Geologia de Portugal, 143.

Azerêdo, A. C., Ramalho, M. M., \& Wright, V. P. (1998). The MiddleUpper Jurassic disconformity in the Lusitanian Basin, Portugal: Preliminary facies analysis and evidence for palaeoclimatic fluctuation. Cuadernos de Geología Ibérica, 24, 99-119.

Azerêdo, A. C., Ramalho, M. M., \& Wright, V. P. (2002). The MiddleLate Jurassic forced regression and disconformity in Central Portugal; eustatic, tectonic and climatic effects on a carbonate ramp system. Sedimentology, 49, 1339-1370.

Bernardes, C. A., Corrochano, A., \& Reis, R. P. (1991). Evolucao do sistema de deltas entrancados do Jurassico superior de S. Martinho do Porto, Bacia Lusitanica; arquitectura sequencial e controlos sedimentares. Comunicações dos Serviços Geológicos de Portugal, 77, 77-88.

Boillot, G., Dupeuble, P.-A., \& Malod, J. A. (1979). Subduction and tectonics on the continental margin off northern Spain. Marine Geology, 32, 53-70.
Boillot, G., Dupeuble, P.-A., \& Mougenot, D. (1974). Géologie du plateau continental portugais entre le Cap Corvoire et le Cap de Sines. Comptes rendus de l'Académie des Sciences, D, 279, 887-890.

Boillot, G., Dupeuble, P.-A., \& Musellec, P. (1973). Carte géologique du plateau continental portugais entre $39^{\circ} 50^{\prime}$ et $41^{\circ} 50^{\prime}$ de latitude Nord. Comptes rendus de l'Académie des Sciences, D, 277, 25-28.

Boillot, G., Dupeuble, P.-A., \& Musellec, P. (1975). Carte géologique du plateau continental nord-portugais. Bulletin de la Société géologique de France, 17, 462-480.

Boillot, G., \& Malod, J. A. (1988). The north and north-west Spanish continental margin: A review. Revista de la Sociedad Geológica de España, 1, 295-316.

Borges, M. E. N., Riding, J. B., Fernandes, P., \& Pereira, Z. (2011). The Jurassic (Pliensbachian to Kimmeridgian) palynology of the Algarve Basin and the Carrapateira outlier, southern Portugal. Review of Palaeobotany and Palynology, 163, 190-204.

Brauckmann, C. (1978). Beitrag zur Flora der Grube Guimarota (OberJura; Mittel-Portugal). Geologica et Palaeontologica, 12, 213-222.

Bromley, R. G. (1996). Trace fossils. Biology, taphonomy and applications (2nd ed. xvi +361 pp.). London: Chapman \& Hall.

Cabral, M. C., Colin, J.-P., Azerêdo, A. C., Ribeiro, B., \& Dantas, P. (2013). New findings of non-marine Upper Jurassic ostracods from the Poruguese western coast. Il Naturalista Siciliano, Serie quarta, 37, 63-65.

Cadenas, P., \& Fernández-Viejo, G. (2016). The Asturian Basin within the north Iberian margin (Bay of Biscay): Seismic characterization of its geometry and its Mesozoic and Cenozoic cover. Basin Research, 29, 521-541.

Camarate França, J., \& Zbyszewski, G. (1963). Carta geológica de Portugal. Noticia explicativa da Folha 26-B Alcobaça (pp. 1-51). Lisboa: Serviços Geológicos de Portugal.

Camarate França, J., Zbyszewski, G., \& Moitinho de Almeida, F. (1960). Carta geológica de Portugal. Noticia explicativa da Folha 26-C Peniche (pp. 1-33). Lisboa: Serviços Geológicos de Portugal.

Carvalho, J., Matias, H., Torres, L., Manuppella, G., Pereira, R., \& Mendes-Victor, L. (2005). The structural and sedimentary evolution of the Arruda and Lower Tagus sub-basins, Portugal. Marine and Petroleum Geology, 22, 427-453.

Castanera, D., Malafaia, E., Silva, B. C., Santos, V. F., \& Belvedere, M. (2020a). New dinosaur, crocodylomorph and swim tracks from the Late Jurassic of the Lusitanian Basin: Implications for ichnodiversity. Lethaia, 54, 271-287.

Castanera, D., Silva, B. C., Santos, V. F., Malafaia, E., \& Belvedere, M. (2020b). Tracking Late Jurassic ornithopods in the Lusitanian Basin of Portugal: Ichnotaxonomic implications. Acta Palaeontologica Polonica, 65, 399-412.

Chafetz, H. S., \& Zhang, J. (1998). Authigenic euhedral megaquartz crystals in a Quaternary dolomite. Journal of Sedimentary Research, 68, 994-1000.

Chiarella, D., Longhitano, S. G., \& Tropeano, M. (2017). Types of mixing and heterogeneities in siliciclastic-carbonate sediments. Marine and Petroleum Geology, 88, 617-627.

Choffat, P. (1885-1888). Description de la faune jurassique du Portugal. Mollusques Lamellibranches. 2e ordre. Asiphonida. Mémoires de la Direction des Travaux géologiques du Portugal, 1-115.

Choffat, P. (1901). Notice préliminaire sur la limite entre le Jurassique et le Crétacé en Portugal. Bulletin de la Société Belge de géologie, de paléontologie et d'hydrologie, 15, 111-140.

Choffat, P. (1893). Description de la faune jurassique du Portugal: Mollusques Lamellibranches. Premier ordre. Siphonida. Mémoires de la Direction des Travaux géologiques du Portugal, 1-39.

Choffat, P. (1947). Description de la faune jurassique du Portugal; brachiopodes. Direction générale des mines et services géologiques, Services Géologiques du Portugal, Lisboa, 1-47.

Davison, I., \& Barreto, P. (2020). Deformation and sedimentation processes, and hydrocarbon accumulations on upturned salt diapir 
flanks in the Lusitanian Basin, Portugal. Petroleum Geoscience, 27, petgeo2019-138.

de Loriol, P. (1890-1891). Description de la faune jurassique du Portugal; embranchement des Echinodermes. Mémoires de la Direction des Travaux géologiques du Portugal, 1-179.

Direcção Geral de Minas e Serviços Geológicos (1959). Carta geológica de Portugal, Escala de 1:50,000. Folha 26-D Caldas da Rainha.

Direcção Geral de Minas e Serviços Geológicos (1960). Carta geológica de Portugal, Escala de 1:50,000. Folha 26-C Peniche.

Direcção Geral de Minas e Serviços Geológicos (1961). Carta geológica de Portugal, Escala de 1:50,000. Folha 26-B Alcobaça.

Direcção Geral de Minas e Serviços Geológicos (1965). Carta geológica de Portugal, Escala de 1:50,000. Folha 30-B Bombarral.

Direcção Geral de Minas e Serviços Geológicos (1966). Carta geológica de Portugal, Escala de 1:50,000. Folha 23-C Leiria.

Direcção Geral de Minas e Serviços Geológicos (1974). Carta geológica de Portugal, Escala de 1:50,000. Folha 23-A Pombal.

Direcção Geral de Minas e Serviços Geológicos (1976). Carta geológica de Portugal, Escala de 1:50,000. Folha 19-C Figueira da Foz.

Duarte, L. V., Silva, R. L., Mendonça Filho, J. G., Poças Ribeiro, N., \& Chagas, R. B. A. (2012). High resolution stratigraphy, palynofacies and source rock potential of the Água de Madeiros Formation (Lower Jurassic), Lusitanian Basin, Portugal. Journal of Petroleum Geology, 35, 105-126.

Duarte, L. V., Silva, R. L., Oliveira, L. C. V., Comas-Rengifo, M. J., \& Silva, F. (2010). Organic-rich facies in the Sinemurian and Pliensbachian of the Lusitanian Basin, Portugal: Total organic carbon distribution and relation to transgressive-regressive facies cycles. Geologica Acta, 8, 325-340.

Dupeuble, P.-A., Boillot, G., \& Mougenot, D. (1987). Upper Jurassic Lowest Cretaceous limestones dredged from the Western Galicia margin. Proceedings of the Ocean Drilling Program, Initial Reports, 103, 99-105.

Ellwood, P. M. (1987). Sedimentology of the Upper Jurassic Abadia Formation and its equivalents, Lusitanian Basin, Portugal, Unpublished PhD thesis (pp. 1-605). Milton Keynes: The Open University. [not seen]

Fatela, F. (1990). Caracterização do Oxfordiano-Kimeridgiano das arribas da Praia dos Salgados. Gaia, 2, 37-39.

Fernandes, P., Rodrigues, B., Borges, M. E. N., Matos, V., \& Clayton, G. (2013). Organic maturation of the Algarve Basin (southern Portugal) and its bearing on thermal history and hydrocarbon exploration. Marine and Petroleum Geology, 46, 210-233.

Flügel, E. (2010). Microfacies of carbonate rocks. Analysis, interpretation and application (pp. 1-984). Heidelberg: Springer.

Friedman, G. M. (1980). Dolomite is an evaporite mineral: Evidence from the rock record and sea-marginal ponds of the Red Sea. Society of Economic Paleontologists and Mineralogists, Special Publication, 28, 69-80.

Fürsich, F. T. (1981a). Invertebrate trace fossils from the Upper Jurassic of Portugal. Comunicações dos Servicos Geológicos de Portugal, 67, 163-168.

Fürsich, F. T. (1981b). Salinity-controlled benthic associations from the Upper Jurassic of Portugal. Lethaia, 14, 203-223.

Fürsich, F. T. (1994). Palaeoecology and evolution of Mesozoic salinitycontrolled benthic macroinvertebrate associations. Lethaia, 26, 327346.

Fürsich, F. T., \& Werner, W. (1984). Salinity zonation of benthic associations in the Upper Jurassic of the Lusitanian Basin (Portugal). Geobios, Mémoir Special, 8, 85-92.

Fürsich, F. T., \& Werner, W. (1985). New species of brackish water Bivalvia from the Upper Jurassic of Portugal. Neues Jahrbuch für Geologie und Paläontologie, Monatshefte, 1985, 438-448.

Fürsich, F. T., \& Werner, W. (1986). Benthic associations and their environmental significance in the Lusitanian Basin (Upper Jurassic,
Portugal). Neues Jahrbuch für Geologie und Paläontologie, Abhandlungen, 172, 271-329.

Fürsich, F. T., \& Werner, W. (1988). The Upper Jurassic Bivalvia of Portugal. Part I. Palaeotaxodonta and Pteriomorphia (Arcoida and Mytiloida). Comunicações dos Servicos Geológicos de Portugal, 73, 103-144.

Fürsich, F. T., \& Werner, W. (1989a). Taxonomy and ecology of Juranomia calcibyssata gen. et sp. nov. - A widespread anomiid bivalve from the Upper Jurassic of Portugal. Geobios, 22, 325-337.

Fürsich, F. T., \& Werner, W. (1989b). The Upper Jurassic Bivalvia of Portugal. Part II. Pteriomorphia (Pteroida exclusive Ostreina). Comunicações dos Servicos Geológicos de Portugal, 74, 105-164.

Fürsich, F. T., \& Werner, W. (1991). Palaeoecology of coralline spongecoral meadows from the Upper Jurassic of Portugal. Paläontologische Zeitschrift, 65, 35-69.

Fürsich, F. T., Werner, W., \& Schneider, S. (2009). Autochthonous to parautochthonous bivalve concentrations within transgressive marginal marine strata of the Upper Jurassic of Portugal. Palaeobiodiversity and Palaeoenvironments, 98(3-4), 161-190.

Fürsich, F. T., Werner, W., Delvene, G., García-Ramos, J. C., BermúdezRochas, D. D., \& Piñuela, L. (2012). Taphonomy and palaeoecology of high-stress benthic associations from the Upper Jurassic of Asturias, northern Spain. Palaeogeography, Palaeoclimatology, Palaeoecology, 358-360, 1-18

Giles, K. A., \& Rowan, M. G. (2012). Concepts in halokinetic-sequence deformation and stratigraphy. In G. I. Alsop, S. G. Archer, A. J. Hartley, N. T. Grant, \& R. Hodgkinson (Eds.), Salt tectonics, sediments and prospectivity (Vol. 363, pp. 7-31). London, Special Publications: Geological Society.

Goldfuss, A. (1833-1841). Petrefacta Germaniae. Teil 2 (1), 1-68, pls 72-96 [1833], (2), 69-140, pls 97-121 [1835], (3), 141-224, pls 122-146 [1837], (4), I-III + 225-312, pls 147-165 [1841]. Arnz \& Co.; Düsseldorf.

González Fernández, B., Menéndez Casares, E., Vicedo, V., Aramburu, C., \& Caus, E. (2014). New insights about the Upper Jurassic Lower Cretaceous sedimentary successions from Asturias (NW Iberian Peninsula). Journal of Iberian Geology, 40, 409-430.

Guéry, F., Montenat, C., \& Vachard, D. (1986). Evolution tectonosédimentaire du Bassin Portugais au Mesozoique suivant la transversale de Peniche (Estremadure). Bulletin des Centres de Recherches Exploration-Production Elf-Aquitaine, 10, 83-94.

Helmdach, F. F. (1968). Oberjurassische Süß- und Brackwasserostrakoden der Kohlengrube Guimarota bei Leiria (Mittelportugal), Unpublished PhD thesis (pp. 1-91). Berlin: Freie Universität. [not seen]

Helmdach, F. F. (1971a). Zur Gliederung limnisch-brackischer Sedimente des portugiesischen Oberjura (Ob. Callovien bis Kimmeridge) mit Hilfe von Ostracoden. Neues Jahrbuch für Geologie und Paläontologie, Monatshefte, 1971, 645-662.

Helmdach, F. F. (1971b). IV. - Stratigraphy and ostracod-fauna from the coalmine Guimarota (Upper Jurassic). In Contribuição para o conhecimento da fauna do Kimeridgiano da Mina de Lignito Guimarota (Leiria, Portugal), II Parte. Memórias dos Serviços Geológicos de Portugal, Nova Serie, 17, 41-88.

Helmdach, F. F. (1974). A contribution to the stratigraphical subdivision of non marine sediments of the Portuguese Upper Jurassic. Comunicações dos Serviços Geológicos de Portugal, 57, 5-22.

Howarth, R. J. \& McArthur, J. M. (2003). SIS look-up table, version 4: 08/03.

Huckriede, R. (1967). Molluskenfaunen mit limnischen und brackischen Elementen aus Jura, Serpulit und Wealden NW-Deutschlands und ihre paläogeographische Bedeutung. Geologisches Jahrbuch, Beihefte, 67, 1-263.

Hudec, M. R., \& Jackson, M. P. A. (2007). Terra infirma: Understanding salt tectonics. Earth-Science Reviews, 82, 1-28. 
Hudec, M. R. \& Jackson M. P. A. (2011). The salt mine: A digital atlas of salt tectonics. Bureau of Economic Geology Udden Book Series, 5 \& American Association of Petroleum Geologists Memoir, 99, 1-305.

Hudson, J. D. (1963a). The recognition of the salinity-controlled mollusc assemblages in the Great Estuarine Series (Middle Jurassic) of the Inner Hebrides. Palaeontology, 6, 318-326.

Hudson, J. D. (1963b). The ecology and stratigraphical distribution of the invertebrate fauna of the Great Estuarine Series. Palaeontology, 6, 327-348.

Instituto Geológico e Mineiro. (1996). Carta geológica de Portugal, Escala de 1:50,000. Folha 30-A Lourinhã (2nd ed.).

Instituto Geológico e Mineiro. (1998). Carta geológica de Portugal, Escala de 1:50,000. Folha 27-A Vila Nove de Ourém (2nd ed.).

Koby, F. (1904-1905). Description de la faune jurassique du Portugal. Polypier du Jurassique superieur (avec une notice stratigraphique par P. Choffat) (pp. 1-167). Lisboa: Commission du Service Géologique du Portugal.

Kühne, W. G. (1961). A mammalian fauna from the Kimmeridgian of Portugal. Nature, 192, 274-275.

Kullberg, J. C., \& Rocha, R. B. (2014). O Jurássico Superior da Bacia Lusitaniana: importância da ligação entre litostratigrafia, cronostratigrafia e cartografia. II $-\mathrm{O} 3^{\circ}$ episódio de rifting. [The Upper Jurassic of the Lusitanian Basin: Importance of linking lithostratigraphy, chronostratigraphy and cartography. II - The 3rd rifting episode.] Comunicações Geológicas, 101, Especial 1, 463467.

Kullberg, J. C., Rocha, R. B., Soares, A. F., Rey, J., Terrinha, P., Azerêdo, A. C., Callapez, P., Duarte, L. V., Kullberg, M. C., Martins, L., Miranda, R., Alves, C., Mata, J., Madeira, J., Mateus, O., Moreira, M., \& Nogueira, C. R. (2013). A Bacia Lusitaniana: estratigrafia, paleogeografia e tectónica. In R. Dias, A. Araújo, P. Terrinha, \& J. C. Kullberg (Eds.), Geologia de Portugal, Volume 2, Geologia Meso-cenozóica de Portugal (Vol. 2, pp. 195-347). Lisboa: Escolar Editora.

Leinfelder, R. R. (1986). Facies, stratigraphy and paleogeographic analysis of upper? Kimmeridgian to upper Portlandian sediments in the environs of Arruda dos Vinhos, Estremadura, Portugal. Münchner Geowissenschaftliche Abhandlungen, Reihe A, 7, 1-215.

Leinfelder, R. R. (1987). Multifactorial control of sedimentation patterns in an ocean marginal basin: The Lusitanian Basin (Portugal) during the Kimmeridgian and Tithonian. Geologische Rundschau, 76, 599631.

Leinfelder, R. R. (2001). Jurassic reef ecosystems. In G. D. Stanley Jr. (Ed.), The history and sedimentology of ancient reef systems (pp. 251-309). New York: Kluwer Academic \& Plenum Publishers.

Leinfelder, R. R., Werner, W., Nose, M., Schmid, D. U., Krautter, M., Laternser, R., Takacs, M., \& Hartmann, D. (1996). Paleoecology, growth parameters and dynamics of coral, sponge and microbolite reefs from the Late Jurassic. Göttinger Arbeiten zur Geologie und Paläontologie, Sonderband, 2, 227-248.

Leinfelder, R. R., \& Wilson, R. C. L. (1998). Third-order sequences in an Upper Jurassic rift-related second-order sequence, central Lusitanian Basin, Portugal. SEPM Special Publication, 60, 507-525.

Lomando, A. J., \& Harris, P. M. (1991). Mixed carbonate-siliciclastic sequences. Society of Economic Paleontologists and Mineralogists, Core Workshop Notes, 15, 1-575.

Lopez-Mir, B., Pierce, C. S. \& Schneider, S. (2019). Passive diapirism in the west Iberian Atlantic margin: Examples from the Lusitanian Basin. AAPG Geoscience Technical Workshop, Euro-Asian Salt Basins, Kraków, April 9-10.

Lopez-Mir, B., Pierce, C. S. \& Schneider, S. (2020). Revisiting the Lusitanian Basin: Exposed Jurassic passive diapirs and halokinetic sequences at the western Iberian Atlantic margin. AAPG Europe Regional Conference 2020, Athens, January 28-29.

Manuppella, G. (1998). Geologic data about the "Camadas de Alcobaca" (Upper Jurassic) north of Lourinhã, and facies variation. Memórias da Academia das Ciências de Lisboa, Classe de Ciências, 37, 1724.

Manuppella, G., Antunes, M. T., Pais, J., Ramalho, M. M. \& Rey, J. (1999). Carta Geologica de Portugal 1: 50.000. Notícia explicativa da Folha 30-A Lourinhã. Serviços Geológicos de Portugal, Lisboa, $1-83$.

Manuppella, G., Zbyszewski, G. \& da Veiga Ferreira, O. (1978). Carta Geologica de Portugal 1: 50.000. Notícia explicativa da Folha 23-A Pombal. Serviços Geológicos de Portugal, Lisboa, 1-62.

Marques, B., Oloriz, F., Caetano, P. S., Rocha, R., \& Kullberg, J. C. (1992). Upper Jurassic of the Alcobaça region. Stratigraphic contributions. Comunicações dos Servicos Geológicos de Portugal, 78, 63-69.

Martin, T. (2001). Mammalian fauna of the Late Jurassic Guimarota ecosystem. Asociación Paleontológica Argentina, Publicación Especial, 7, 123-126.

Martin, T., \& Krebs, B. (2000). Guimarota - a Jurassic ecosystem (pp. 1156). Munich: Verlag Dr. Friedrich Pfeil.

Martins, J. M. (2008). Litostratigrafia das séries de meio marinho interno do Jurássico Médio da região de Condeixa-Sicó-Alvaiázere (Portugal). Comunicações Geológicas, 95, 27-49.

Mateus, O. (2006). Late Jurassic dinosaurs from the Morrison Formation (USA), the Lourinhã and Alcobaça Formations (Portugal), and the Tendaguru beds (Tanzania): A comparison. Bulletin of the New Mexico Museum of Natural History and Science, 36, 223-231.

Matias, H., Kress, P., Terrinha, P., Mohriak, W. U., Menezes, P. T. L., Matias, L., Santos, F., \& Sandnes, F. (2011). Salt tectonics in the western Gulf of Cadiz, Southwest Iberia. AAPG Bulletin, 95, 16671698.

Maync, W. (1959). The foraminiferal genera Spirocyclina and Iberina. Micropaleontology, 5, 33-69.

McAlpine, K. D. (1990). Mesozoic stratigraphy, sedimentary evolution, and petroleum potential of the Jeanne d'Arc Basin, Grand Banks of Newfoundland. Geological Survey of Canada Paper, 89-17, 1-50.

McPherson, J. G. (1979). Calcrete (caliche) palaeosols in fluvial red beds of the Aztec siltstone (upper Devonian), South Victoria Land, Antarctica. Sedimentary Geology, 22, 267-285.

Miall, A. D. (1996). The geology of fluvial deposits: Sedimentary facies, basin analysis and petroleum geology (pp. 1-582). Berlin: Heidelberg, Springer.

Mocho, P., Royo-Torres, R., Escaso, F., Malafaia, E., de Miguel Chaves, C., Narváez, I., Pérez-García, A., Pimentel, N., Silva, B. C., \& Ortega, F. (2017). Upper Jurassic sauropod record in the Lusitanian Basin (Portugal): Geographical and lithostratigraphical distribution. Palaeontologia Electronica, 20.2.27A, 1-50.

Mohr, B. A. R. (1989). New palynologic information on the age and environment of Upper Jurassic and Lower Cretaceous vertebrate localities of the Iberian Peninsula (eastern Spain and Portugal). Berliner geowissenschaftliche Abhandlungen, A, 106, 291-301.

Mohr, B. A. R., \& Schmidt, D. (1988). The Oxfordian/Kimmeridgian boundary in the region of Porto de Mós (Central Portugal): Stratigraphy, facies and palynology. Neues Jahrbuch für Geologie und Paläontologie, Abhandlungen, 176, 245-267.

Moitinho de Almeida, F., Mouterde, R., Perrot, C., Teixiera, C., Tahdeu, D., \& Zbyszewski, G. (1958). Portugal. In P. Pruvost (Ed.), Lexique Stratigraphique International (Vol. 1, pp. 97-142).

Mongin, D. (1967). Les mollusques du Bathonien saumâtre du Moyen Atlas. Notes et Mémoires du Service Géologique du Maroc, 200, 37-94.

Montenat, C., \& Guéry, F. (1984). L' intrusion diapirique de Caldas da Rainha et l'halocinèse jurassique sur la marge portugaise. Comptes Rendus de l'Académie des Sciences, Série 2, Mécanique, Physique, Chimie, Astronomie, Sciences de la terre et des planets, 298(20), 901-906.

Montenat, C., Guery, F., Jamet, M., \& Berthou, P. Y. (1988). Mesozoic evolution of the Lusitanian Basin; comparison with the adjacent 
margin. Proceedings of the Ocean Drilling Program, Scientific Results, 103, 757-775.

Neto de Carvalho, C. (2016). Psilonichnus Fürsich, 1981 in its typelocality (Praia do Salgado, western Portugal). Comunicações Geológicas, 103, Especial 1, 13-22.

Neto de Carvalho, C., \& Baucon, A. (2010). Jurassic sex in the beach? Macanopsis from the Kimmeridgian of Praia do Salgado (Portugal). In J. M. Gibert, F. Muñiz, E. Mayoral, \& Z. Belaústegui (Eds.), Workshop on crustacean bioturbation, fossil and recent Abstract Volume, Lepe, May 31-June 4, 71-75.

Neto de Carvalho, C., Rodrigues, N. P. C., Viegas, P. A., Baucon, A., \& Santos, V. F. (2010). Patterns of occurrence and distribution of crustacean ichnofossils in the Lower Jurassic - Upper Cretaceous of Atlantic occidental margin basins, Portugal. Acta Geologica Polonica, 60, 19-28.

Nose, M. \& Leinfelder, R. R. (1997). Upper Jurassic coral communities within siliciclastic settings (Lusitanian Basin, Portugal): Implications for symbiotic and nutrient strategies. Proceedings of the 8th international coral reef symposium, Panama, 1755-1760.

Parant, B. (1963). Etude stratigraphique des flancs du diapir d'Obidos. Unpublished report, Companhia Portuguesa dos Petróleos, Lisbon, $1-8$.

Pena dos Reis, R., Dinis, J. L., Proença Cunha, P., \& Trincão, P. (1996). Upper Jurassic sedimentary infill and tectonics of the Lusitanian Basin (Western Portugal). GeoResearch Forum, 1-2, 377-386.

Pimentel, N., \& Pena dos Reis, R. (2016). Petroleum systems of the west Iberian margin: A review of the Lusitanian Basin and the deep offshore Peniche Basin. Journal of Petroleum Geology, 39, 305326.

Pinheiro, L., Wilson, R. C. L., Pena dos Reis, R., Whitmarsh, R. B., \& Ribeiro, A. (1996). The western Iberia margin: A geophysical and geological overview. Proceedings of the Ocean Drilling Program, Scientific Results, 149, 13-30.

Pratsch, J. C. (1958). Stratigraphisch-tektonische Untersuchungen im Mesozoikum von Algarve (Südportugal). Geologisches Jahrbuch, Beihefte, 30, 1-123.

Rao, V.P. (1990). On the occurrence of caliche pisolites from the western continental shelf of India. Sedimentary Geology, 69, 13-19.

Rasmussen, E. S., Lomholt, S., Andersen, C., \& Vejbaek, O. V. (1998). Aspects of the structural evolution of the Lusitanian Basin in Portugal and the shelf and slope area offshore Portugal. Tectonophysics, 300, 199-225.

Ravnas, R., Windelstad, J., Mellere, D., Nottvedt, A., Stuhr Sjoblom, T., Steel, R. J., \& Wilson, R. C. L. (1997). A marine Late Jurassic synrift succession in the Lusitanian Basin, western Portugal; tectonic significance of stratigraphic signature. Sedimentary Geology, 114, 237-266.

Ribeiro, A., Kullberg, M. C., Kullberg, J. C., Manuppella, G., \& Phipps, S. (1990). A review of alpine tectonics in Portugal: Foreland detachment in basement and cover rocks. Tectonophysics, 184, 357-366.

Ruget-Perrot, C. (1961). Études stratigraphiques sur le Dogger et le Malm Inférieur du Portugal au nord du Tage. Bajocien, Bathonien, Callovien, Lusitanien. Memórias dos Serviços Geológicos de Portugal, nova série, 7, 1-197.

Sánchez-Beristain, F., \& Reitner, J. (2019). Numerical analyses of selected microencursters from the Cipit boulders of the St Cassian Formation (Dolomites, NE Italy): Palaeoecological implications. Lethaia, 52, 285-297.

Schneider, S., Fürsich, F. T., Schulz-Mirbach, T., \& Werner, W. (2010a). Ecophenotypic plasticity versus evolutionary trends - Morphological variability in Upper Jurassic bivalve shells from Portugal. Acta Palaeontologica Polonica, 55, 701-732.

Schneider, S., Fürsich, F. T., \& Werner, W. (2009). Sr-isotope stratigraphy of the Upper Jurassic of Central Portugal (Lusitanian Basin) based on oyster shells. International Journal of Earth Sciences, 98, 1949-1970.

Schneider, S., Fürsich, F. T., \& Werner, W. (2010b). Marking the Kimmeridgian-Tithonian transition with a bivalve - Protocardia gigantea sp. nov. (Bivalvia: Cardiidae) and its relatives from the Lusitanian Basin (Portugal). Neues Jahrbuch für Geologie und Paläontologie, Abhandlungen, 258, 167-184.

Schneider, S., Fürsich, F. T., \& Werner, W. (2011). Biometric methods for species recognition in Trigonia Bruguière (Bivalvia; Trigoniidae) - A case study from the Upper Jurassic of Western Europe. Paläontologische Zeitschrift, 85, 257-267.

Schneider, S., \& Werner, W. (2007). Colour pattern preservation in Fuersichella n. gen. (Gastropoda: Neritopsoidea), bivalves, and echinid spines from the Upper Jurassic of Portugal. Beringeria, 37, $143-160$.

Schudack, M. E. (1993). Charophyten aus dem Kimmeridgium der Kohlengrube Guimarota (Portugal). Mit einer eingehenden Diskussion zur Datierung der Fundstelle. Berliner geowissenschaftliche Abhandlungen, E9, 211-231.

Schudack, M. E. (2000a). Geological setting and dating of the Guimarota beds. In T. Martin \& B. Krebs (Eds.), Guimarota - a Jurassic ecosystem (pp. 21-26). Munich: Verlag Dr. Friedrich Pfeil.

Schudack, M. E. (2000b). Ostracods and charophytes from the Guimarota beds. In T. Martin \& B. Krebs (Eds.), Guimarota - a Jurassic ecosystem (pp. 33-36). Munich: Verlag Dr. Friedrich Pfeil.

Seilacher, A. (1967). Bathymetry of trace fossils. Marine Geology, 5, 413-428.

Sharpe, D. (1850). On the secondary district of Portugal, which lies on the north of the Tagus. Quarterly Journal of the Geological Society of London, 6, 135-201.

Sowerby, J. de C. (1823-1845). The mineral conchology of Great Britain. Meredith, London, pls. 384-648; 384-443 [1823], 444485, 486-503 [1824], 504-544 [1826], 545-580 [1827], 581-597 [1828], 598-609 [1829], Index System [1835], alphabetical index to vol. 1-6, 614-618 [1840], 619-623 [1841], 624-628 [1843], 629643 [1844], 644-648 [1845].

Stam, B. (1986). Quantitative analysis of Middle and Late Jurassic foraminifera from Portugal and its implications for the Grand Banks of Newfoundland. Utrecht Micropaleontological Bulletins, 34, 1-168.

Taylor, A. M., Gowland, S., Leary, S., Keogh, K. J., \& Martinius, A. W. (2014). Stratigraphical correlation of the Late Jurassic Lourinhã Formation in the Consolação Sub-basin (Lusitanian Basin), Portugal. Geological Journal, 49, 143-162.

Teixeira, C., \& Zbyszewski, G. (1968). Carta geológica de Portugal. Noticia explicativa da Folha 23-C Leiria (pp. 1-99). Lisboa: Serviços Geológicos de Portugal.

Terrinha, P., Ribeiro, C., Kullberg, J. C., Lopes, C., \& Ribeiro, A. (2002). Compressive episodes and faunal isolation during rifting, Southwest Iberia. The Journal of Geology, 110, 101-113.

Van Erve, A., \& Mohr, B. A. R. (1988). Palynological investigations of the Late Jurassic microflora from the vertebrate locality Guimarota coal mine (Leiria, Central Portugal). Neues Jahrbuch für Geologie und Paläontologie, Monatshefte, 1988, 246-262.

Walker, O. A., Alves, T. M., Hesselbo, S. P., Pharao, T., Nuzzo, M., \& Mattos, N. H. (2021). Significance of Upper Triassic to Lower Jurassic salt in the identification of palaeo-seaways in the North Atlantic. Marine and Petroleum Geology, 123, 1-16.

Werner, W. (1986). Palökologische und biofazielle Analyse des Kimmeridge (Oberjura) von Consolação, Mittelportugal. Zitteliana, 13, 3-109.

Wierzbowski, A., Atrops, F., Grabowski, J., Hounslow, M., Matyja, B. A., Olóriz, F., Page, K., Parent, H., Rogov, M. A., Schweigert, G., Villaseñor, A. B., Wierzbowski, H., \& Wright, J. K. (2016). Towards a consistent Oxfordian-Kimmeridgian global boundary: Current state of knowledge. Volumina Jurassica, 14, 14-49. 
Wierzbowski, H., Anczkiewicz, R., Pawlak, J., Rogov, M. A., \& Kuznetsov, A. B. (2017). Revised Middle-Upper Jurassic strontium isotope stratigraphy. Chemical Geology, 466, 239-255.

Williamson, M. A. (1987). A quantitative foraminiferal biozonation of the Late Jurassic and Early Cretaceous of the East Newfoundland Basin. Micropaleontology, 33, 37-65.

Wilson, R. C. L. (1975). Some examples of shoaling deposits from the Upper Jurassic of Portugal. In R. N. Ginsburg (Ed.), Tidal deposits (pp. 363-371). Berlin: Springer.

Wilson, R. C. L. (1979). A reconnaisance study of Upper Jurassic sediments of the Lusitanian Basin. Ciencias da Terra (UNL), 5, 53-84.

Wilson, R. C. L. (1988). Mesozoic development of the Lusitanian Basin, Portugal. Revista de la Sociedad Geológica de España, 1, 393-407.

Wilson, R. C. L., Hiscott, R. N., Willis, M. G., \& Gradstein, F. M. (1989). The Lusitanian Basin of west Central Portugal: Mesozoic and
Tertiary tectonic, stratigraphy and subsidence history. American Association of Petroleum Geologists Memoir, 46, 341361.

Witt, W. (1977). Stratigraphy of the Lusitanian Basin. Shell Prospex Portuguesa, unpublished report, 1-61.

Yin, J., Fürsich, F. T., \& Werner, W. (1995). Reconstruction of palaeosalinity using carbon isotopes and benthic associations: A comparison. Geologische Rundschau, 84, 223-236.

Zbyszewski, G., \& Moitinho de Almeida, F. (1960). Carta geológica de Portugal. Noticia explicativa da Folha 26-D Caldas da Rainha (pp. 1-56). Lisboa: Serviços Geológicos de Portugal.

Publisher's note Springer Nature remains neutral with regard to jurisdictional claims in published maps and institutional affiliations. 